\title{
A review of heat transfer enhancement techniques in plate heat exchangers
}

\author{
Zhang, Ji; Zhu, Xiaowei; Mondejar, Maria E.; Haglind, Fredrik
}

\section{Published in:}

Renewable and Sustainable Energy Reviews

Link to article, DOI:

10.1016/j.rser.2018.11.017

Publication date:

2019

Document Version

Peer reviewed version

Link back to DTU Orbit

Citation (APA):

Zhang, J., Zhu, X., Mondejar, M. E., \& Haglind, F. (2019). A review of heat transfer enhancement techniques in plate heat exchangers. Renewable and Sustainable Energy Reviews, 101, 305-328.

https://doi.org/10.1016/j.rser.2018.11.017

\section{General rights}

Copyright and moral rights for the publications made accessible in the public portal are retained by the authors and/or other copyright owners and it is a condition of accessing publications that users recognise and abide by the legal requirements associated with these rights.

- Users may download and print one copy of any publication from the public portal for the purpose of private study or research.

- You may not further distribute the material or use it for any profit-making activity or commercial gain

- You may freely distribute the URL identifying the publication in the public portal

If you believe that this document breaches copyright please contact us providing details, and we will remove access to the work immediately and investigate your claim. 


\title{
A review of heat transfer enhancement techniques in plate heat exchangers
}

\author{
Ji Zhang*, Xiaowei Zhu, Maria E. Mondejar, Fredrik Haglind \\ Department of Mechanical Engineering, Technical University of Denmark, Nils Koppels Allé, \\ Building 403, 2800 Kongens Lyngby, Denmark
}

\begin{abstract}
Plate heat exchangers have been widely applied in numerous industrial applications since their first commercial exploitation in the 1920s. Enhancing the thermal-hydraulic performance of plate heat exchangers is of crucial importance for the energy conversion as well as for the improvement of the system economy, through savings in the capital investment. The efficiency of a plate heat exchanger can be improved either by optimizing its geometry or using heat transfer enhancement techniques. This paper provides a comprehensive review of previous works regarding the effects of chevron corrugation geometrical parameters on the performance of plate heat exchangers, and the application of heat transfer enhancement techniques in plate heat exchangers, focusing on passive surface techniques and the use of nanofluids. The objective of the paper is not only to describe relevant studies, but also to provide an understanding of the heat transfer mechanisms governing the results, and to evaluate and compare the different heat transfer enhancement techniques. In addition, prospective directions for future research are provided. The review indicates that for the chevrontype plate heat exchanger, the chevron angle is the most influential geometrical parameter by changing the flow structures in the single-phase heat transfer; meanwhile the chevron angle has a significant influence on the heat transfer regions characterized by convection in the two-phase heat transfer. An analysis based on the performance evaluation criteria suggests that the thermal-
\end{abstract}

\footnotetext{
* Corresponding author. Tel.: +45 452513 87; fax: +45 45251961

E-mail address: jizhang@ mek.dtu.dk (Ji Zhang)
} 
hydraulic performances of the studies with different geometrical parameters and enhancement techniques are generally higher at low Reynold numbers. Furthermore, the review and analysis indicate that the capsule-type embossing surface and the microstructured surface with a nano- and microporous layer are the enhancement techniques that present the highest performance in singlephase and two-phase heat transfer, respectively.

Keywords: heat transfer enhancement, plate heat exchanger, thermal-hydraulic performance, passive surface technique, nanofluid, chevron corrugation 


\begin{tabular}{|c|c|c|c|}
\hline \multicolumn{4}{|c|}{ Nomenclature } \\
\hline \multicolumn{2}{|c|}{ Symbols } & \multicolumn{2}{|c|}{ Greek Symbols } \\
\hline$A$ & momentum along the corrugation, $\mathrm{kg} \cdot \mathrm{m} / \mathrm{s}$ & $\gamma$ & aspect ratio of chevron corrugation \\
\hline $\mathrm{b}$ & amplitude of corrugation, $\mathrm{m}$ & $\beta$ & chevron angle, ${ }^{\circ}$ \\
\hline$c_{p}$ & specific isobaric heat capacity, $\mathrm{J} / \mathrm{kg} \mathrm{K}$ & $\varphi$ & volume concentration, $\%$ \\
\hline $\mathrm{D}$ & diameter, $\mathrm{m}$ & $\mu$ & dynamic viscosity, Pa.s \\
\hline$f$ & friction factor & $\rho$ & density, $\mathrm{kg} / \mathrm{m}^{3}$ \\
\hline $\boldsymbol{F}$ & momentum of main flow, $\mathrm{kg} \cdot \mathrm{m} / \mathrm{s}$ & $\lambda$ & corrugation pitch, $\mathrm{m}$ \\
\hline $\mathrm{h}$ & heat transfer coefficient, $\mathrm{W} / \mathrm{m}^{2} \mathrm{~K}$ & $\Delta$ & difference \\
\hline$j$ & Colburn $\mathrm{j}$ factor & $\delta$ & thickness of plate, $\mathrm{m}$ \\
\hline j/f & area goodness factor & $\eta$ & enlargement factor of corrugation surface \\
\hline$k$ & thermal conductivity, W/m K & $\omega$ & weight concentration, $\%$ \\
\hline $\mathrm{L}$ & length, $\mathrm{m}$ & & \\
\hline $\mathrm{N}$ & plate number & \multicolumn{2}{|c|}{ Abbreviations } \\
\hline $\mathrm{Nu}$ & Nusselt number & & \\
\hline $\mathrm{P}$ & pressure, $\mathrm{Pa}$ & AARD & average absolute relative deviations \\
\hline $\mathrm{Pe}$ & Peclet number & CFD & computational fluid dynamics \\
\hline $\operatorname{Pr}$ & Prandtl number & CNT & carbon nanotube \\
\hline $\mathrm{R}$ & roughness, $\mu \mathrm{m}$ & EG & ethylene glycol \\
\hline $\operatorname{Re}$ & Reynolds number & MGA & micro-genetic algorithm \\
\hline $\mathrm{S}$ & distance between two plates, $\mathrm{m}$ & MWCNT & Multi-walled carbon nanotube \\
\hline \multirow[t]{2}{*}{$\mathrm{W}$} & width, m & PHE & plate heat exchanger \\
\hline & & PEC & performance evaluation criterion \\
\hline \multicolumn{2}{|c|}{ Subscripts } & SEM & scanning electron microscope \\
\hline cri & critical & & \\
\hline en & enhancement technique & & \\
\hline $\begin{array}{l}\mathrm{p} \\
\text { ref }\end{array}$ & $\begin{array}{l}\text { port } \\
\text { reference }\end{array}$ & & \\
\hline
\end{tabular}




\section{Contents}

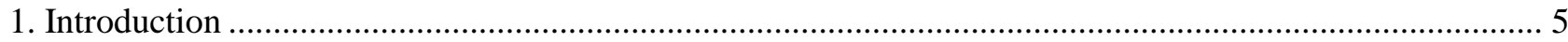

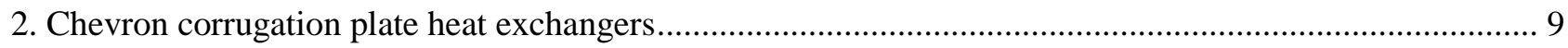

2.1 Effect of geometrical parameters on the single-phase heat transfer ..................................................... 11

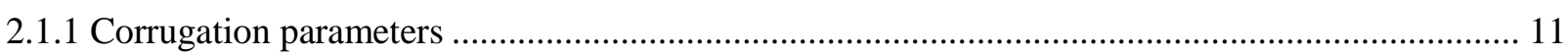

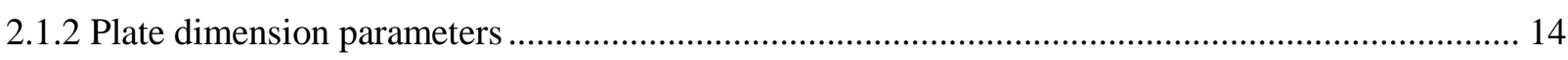

2.2 Effect of geometrical parameters on the two-phase heat transfer......................................................... 18

3. Enhancement techniques in plate heat exchangers .................................................................................. 21

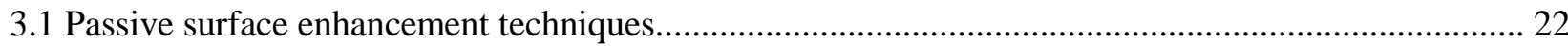

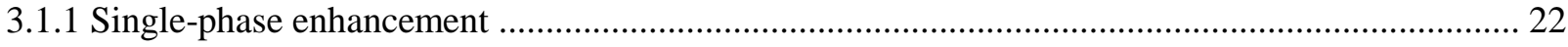

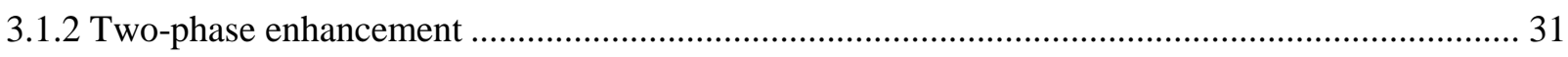

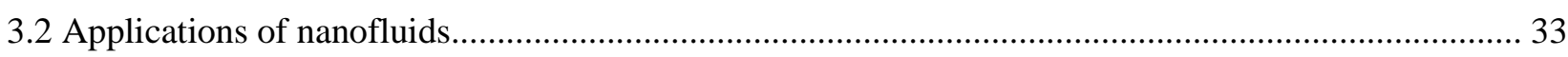

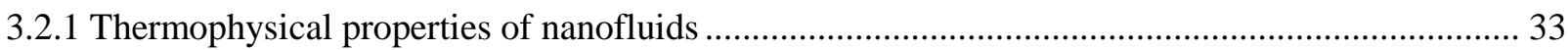

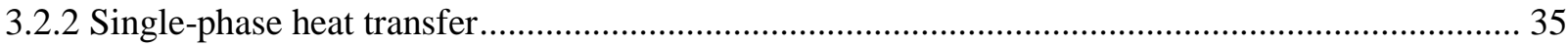

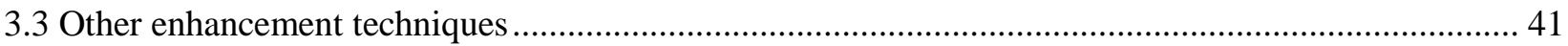

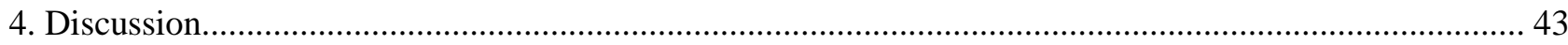

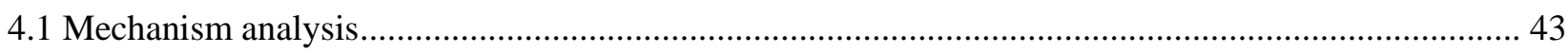

4.1.1 Effects of geometrical parameters on the single-phase heat transfer............................................ 43

4.1.2 Effects of geometrical parameters on the two-phase heat transfer ................................................ 46

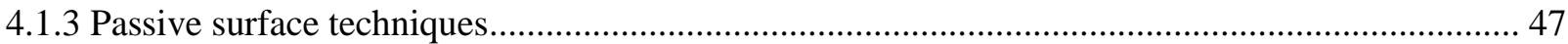

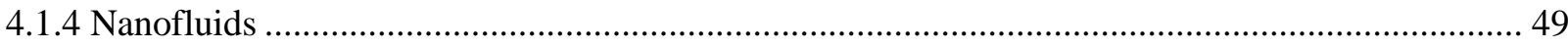

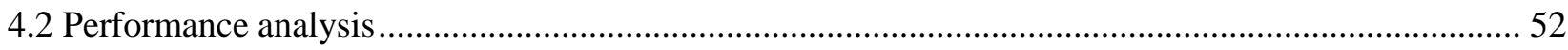

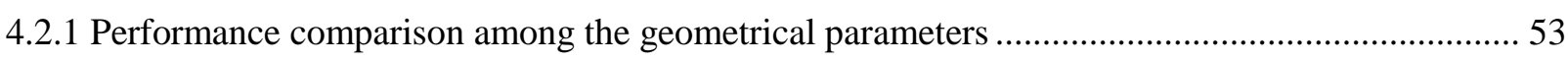

4.2.2 Performance comparison among the enhancement techniques ................................................... 55

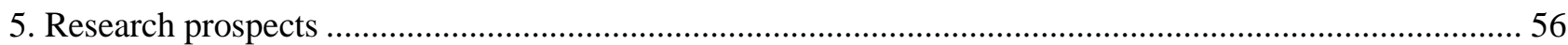

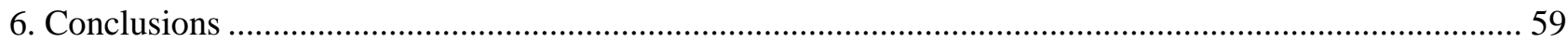

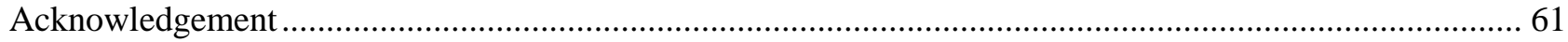

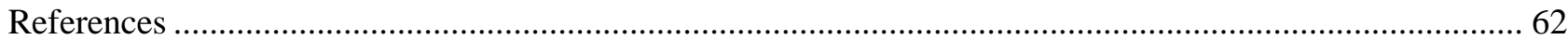




\section{Introduction}

Heat exchangers are important components in the processing, power generation, HVAC/R, transportation and manufacturing industries. Over the past decades, environmental concerns with respect to thermal, air, and water pollution, as well as the disposal of waste, have motivated the need for energy savings and the increased exploitation of renewable energy sources. These facts have increased the emphasis on the use of high efficiency heat exchangers and have led to the development of more compact heat exchangers. Plate heat exchangers (PHEs) are categorized at the lower end of the compactness spectrum [1], and they are widely used for numerous industrial applications, featuring compactness, effectiveness, design flexibility and low cost. As shown in Figure 1, a PHE usually consists of a number of corrugated or embossed metal plates in mutual contact. Each plate has four apertures serving as inlet and outlet ports, and seals designed to direct the fluids in alternate flow passages. Adjacent plates form the flow passages so that the two streams exchange heat while passing through alternate channels.

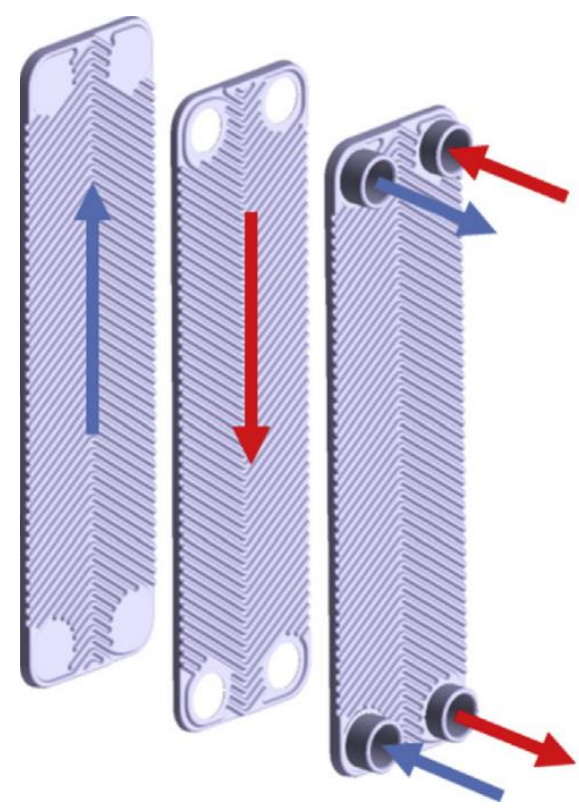

Figure 1 Schematic diagram of hot and cold fluid flows in alternate passages in PHE [2].

As noted by Thulukkanam [3], over 60 different plate patterns for the PHEs have been 
developed worldwide. During the last decades, one of the plate patterns, the chevron corrugation, has proved to be the most successful design [3-5] and the majority of manufacturers offer it [1]. Since then, large research efforts have focused on the design and optimization of chevron corrugation PHEs, where the different geometrical parameters of the chevron corrugation play a crucial role. Numerous research works, both experimental and numerical, have either studied the effects of geometrical parameters on thermal-hydraulic performance or addressed the multiobjective optimization of geometrical parameters according to the demands of practical applications. Generally, the results of these studies indicate that the geometrical parameters affect significantly the performance of PHEs, and attaining the optimal design of the plate geometrical configuration is one of the keys to increasing the performance of chevron corrugation PHEs.

There has been increasing research on the topic of heat transfer enhancement techniques in PHEs, aiming at improving the thermal-hydraulic performance of PHEs by using different enhancement techniques rather than only focusing on the optimal design of the chevron corrugation PHEs. Heat transfer enhancement is normally referred to as the increase in the heat transfer coefficient, although it also implies the reduction of the size of the heat exchange equipment for a given duty, the increase of the capacity of existing heat exchange equipment, or the reduction of the approach temperature difference [6]. The heat transfer enhancement techniques can be classified either as active or passive $[7,8]$, depending on whether external power is required or not. In the literature, passive surface techniques (i.e. heat transfer enhancing surfaces that are different from the chevron corrugation), nanofluids (i.e. fluids with colloidal suspension of nanoparticles), and other enhancement techniques (i.e. active techniques and other passive techniques which are different from the passive surface techniques and nanofluids) have been applied in PHEs, showing their great potential to improve the heat exchanger thermal-hydraulic performance.

This background motivates an overview including these two aspects, i.e. the geometrical 
parameters of the chevron corrugation and the application of heat transfer enhancement techniques in the PHEs. Although the chevron-corrugated surface can also be considered as a kind of passive surface technique if compared with the flat surface, it needs to be separated from the enhancement techniques, since it is the widest used technology currently on the market. Researchers have published a number of review papers related to PHEs. However, most of them presented an overview of heat transfer and pressure drop correlations [5,9-13], or a general overview of PHEs including the selections of material and plate pattern, corrosion, fouling issues and maintenance of PHEs [14]. Only three previous review papers partly addressed the geometrical parameters of the chevron corrugation and the application of heat transfer enhancement techniques. The review of Abu-Khader [15] mainly focused on the advances made with respect to the thermal-hydraulic performance, two-phase heat transfer models in PHEs, fouling and corrosion, and welded type PHEs, while it included only a small fraction of the previous studies concerning the geometrical parameters of the chevron corrugation. Elmaaty et al. [16] reviewed the structure, thermal performance, and the advantages and limitations of PHEs. Research regarding PHEs with novel surface structures or PHEs employing nanofluids as working fluids were to some extent covered, corresponding to the applications of two kinds of heat transfer enhancement techniques, a passive surface technique and the use of nanofluids, respectively. However, numerous relevant previous works were not included. Kumar et al. [17] presented an overview of the application of nanofluids in PHEs, involving most of the existing studies. It needs to be stressed that Refs. [16,17] included reviews of previous works, without any analysis of the results of the reviewed papers.

This paper provides a comprehensive review of previous works regarding the effects of chevron corrugation geometrical parameters on the performance of PHEs, and the application of heat transfer enhancement techniques in PHEs, focusing on passive surface techniques, and the use of nanofluids. The objective of this paper is not only to describe relevant studies, but also to provide 
an understanding of the heat transfer mechanisms governing the results, and to evaluate and compare the different heat transfer enhancement techniques. This paper summarizes the heat transfer and pressure drop characteristics of PHEs for different geometrical parameters of chevron corrugation and enhancement techniques and discusses the governing heat transfer mechanisms. In addition, based on data available in the literature, comparisons of the thermal-hydraulic performance of the different techniques using the performance evaluation criterion (PEC) are made; Section 4.2, Eq. (3) provides a definition of the PEC. The key conclusions drawn from the state-ofthe-art descriptions along with suggestions for future research are also presented in the paper.

Several novel elements are included in this paper: i) a comprehensive overview of previous works within the aforementioned two fields; ii) a discussion about the heat transfer mechanisms of the chevron corrugation geometrical parameters and enhancement techniques in PHEs; and iii) an analysis based on the PEC comparing the effects of different geometrical parameters of chevron corrugation and enhancement techniques.

The paper is structured as follows. Section 2 provides a review of the studies concerning the effects of geometrical parameters of chevron corrugation on thermal-hydraulic performance. Section 3 is dedicated to the studies investigating the application of enhancement techniques for PHEs including passive surface techniques, nanofluids and other enhancement techniques. Section 4 presents a discussion of the various studies, including the mechanisms of the different heat transfer processes and a comparison of the PECs. Section 5 outlines some possible directions for future research, and Section 6 lists the conclusions of the paper. 


\section{Chevron corrugation plate heat exchangers}

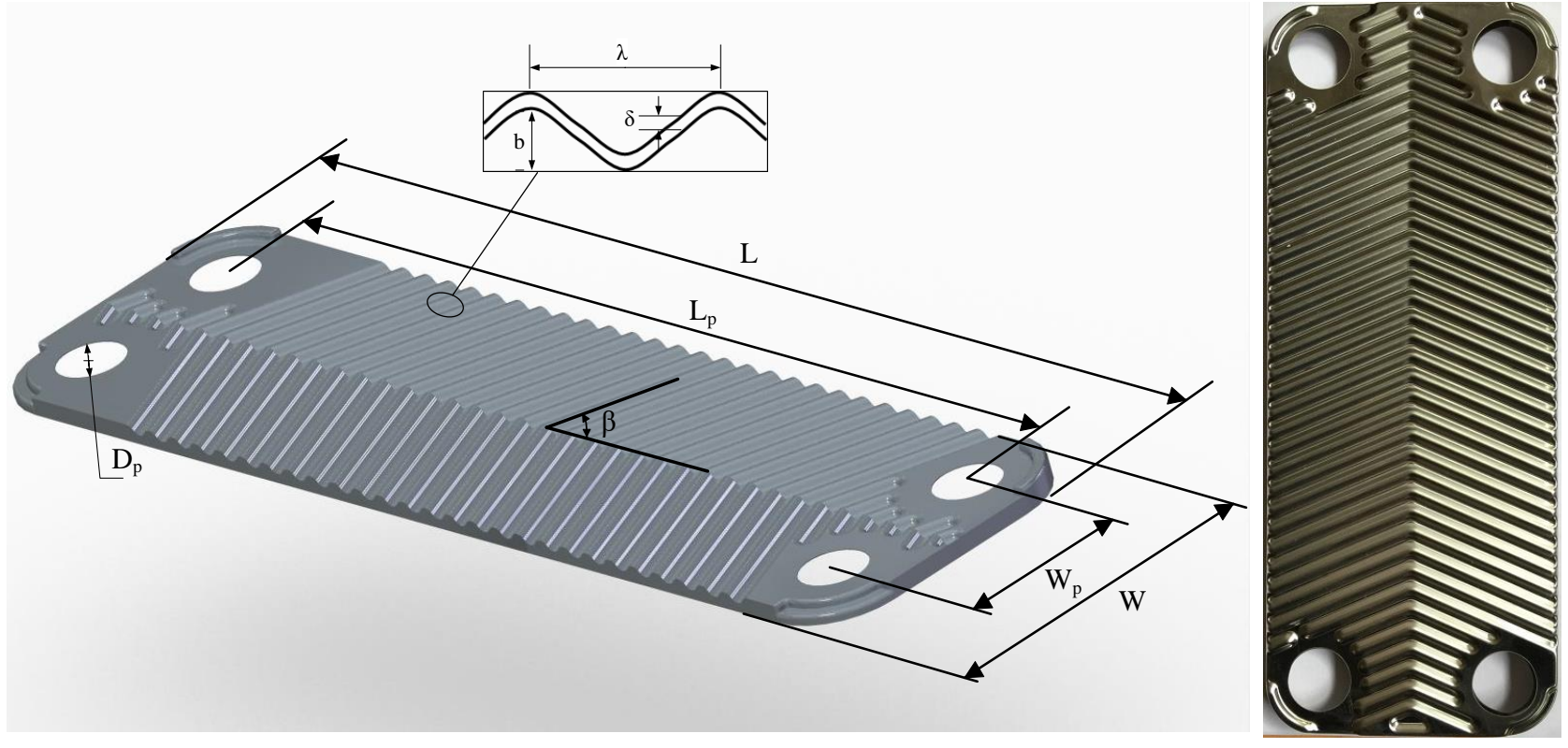

Figure 2 Diagram and image of a chevron corrugation plate.

Figure 2 depicts a schematic figure, including illustrations of the most important geometrical parameters, and a picture of a chevron corrugation plate. Generally, geometrical parameters can be divided into two categories: corrugation and plate dimension. The former one includes the chevron angle $\beta$, the wavelength of surface corrugation $\lambda$ and the corrugation depth $b$, while the plate length $\mathrm{L}$ and width $\mathrm{W}$, the effective length $\mathrm{L}_{p}$ and width $\mathrm{W}_{p}$ between ports, and the port diameter $\mathrm{D}_{p}$ belong to the latter. In addition, two parameters, the aspect ratio $\gamma$ and enlargement factor of corrugation $\eta$, which are determined by the corrugation wavelength and depth, are defined as follows:

$$
\begin{gathered}
\gamma=\frac{2 b}{\lambda} \\
\eta=\frac{1}{6}\left[1+\sqrt{1+\left(\frac{\pi \gamma}{2}\right)^{2}}+4 \sqrt{1+0.5\left(\frac{\pi \gamma}{2}\right)^{2}}\right] .
\end{gathered}
$$

In the open literature, these two dimensionless numbers are considered as the most important 
corrugation parameters to express the effectiveness of corrugation on PHEs.

Researchers have performed numerous research works, both experimental and numerical, to study the effects of geometrical parameters on single-phase convective heat transfer. In contrast, the studies on two-phase heat transfer in chevron type PHEs are relatively few. In both the single-phase and two-phase studies, $\beta$ is the most studied parameter. In addition to $\beta$, researchers have also commonly studied a parameter such as $\eta, \gamma, \lambda$ and $b$, expressing the effectiveness of the corrugation. The percentages of the studies, in total covering 62 journal and conference papers published from 1983 to 2018 , on heat transfer patterns, geometrical parameters and research methods are presented in Figure 3.

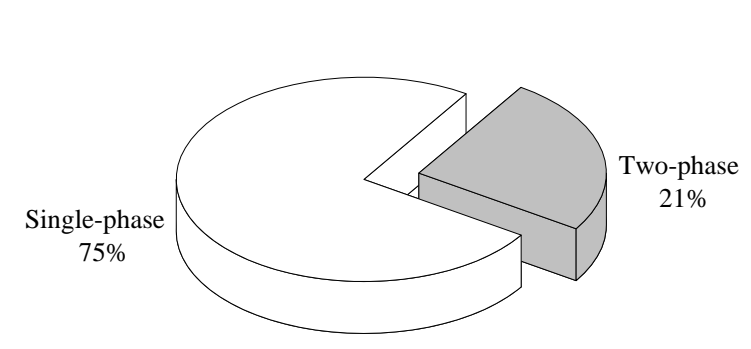

(a)

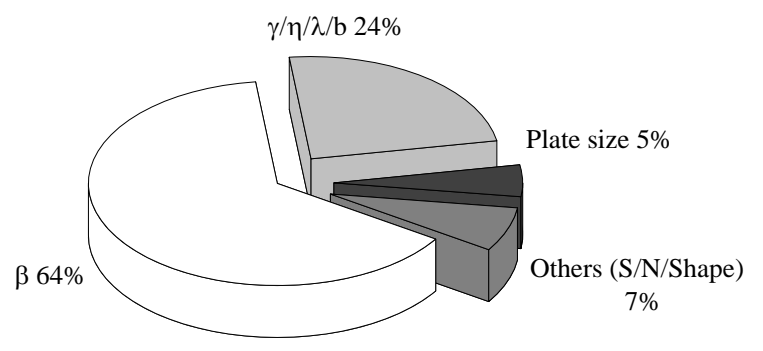

(b)

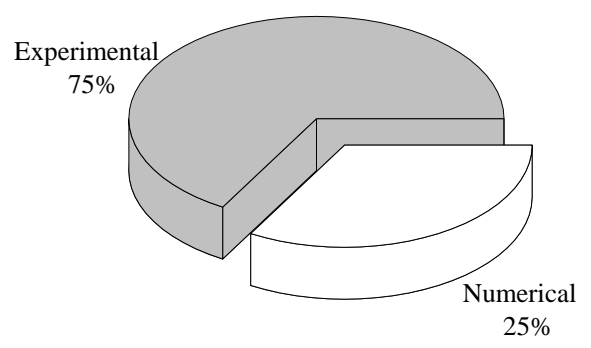

(c)

Figure 3 The percentages of the studies related to research patterns regarding (a) the geometrical parameters in single-phase and two-phase, (b) the types of geometry parameters, and (c) the 
research method.

\subsection{Effect of geometrical parameters on the single-phase heat transfer}

Table 1 summarizes the various studies of geometrical parameters in the single-phase heat transfer, and the next two subsections address, respectively, the corrugation parameters and the plate dimension parameters.

\subsubsection{Corrugation parameters}

Focke et al. $[18,19]$ conducted an experimental investigation with a visualization technique, studying the effect of $\beta$ on the thermal-hydraulic performance of PHEs. The results demonstrate that $\beta$ is a major parameter influencing the performance of PHEs, which the authors attribute to the fact that a change in $\beta$ affects the basic flow structure and thereby influences the pressure drop and heat transfer. Moreover, the paper addresses the flow patterns for different $\beta$. Specifically, the fluid flows predominantly along the furrows when $\beta \leq 60^{\circ}$, while parallel zig-zag patterns appear at $\beta=$ $80^{\circ}$

Manglik et al. $[20,21]$ presented a set of experiments to study the effects of $\beta$ and $\gamma$ on heat transfer and pressure drop. The results indicate that increasing $\beta$ (and/or $\gamma$ ) leads to the increase of both the Nusselt number $\mathrm{Nu}$ and the friction factor $f$ in chevron corrugation PHEs. Combined with the evolution of swirl flows, the authors found that larger $\gamma$ (deeper grooves) induced higher coreflow peak velocities of lateral vortices or recirculation zones developed in the channel troughs.

M. Hessami et al. [22,23] investigated experimentally the thermal performance and pressure loss in two PHEs with $\beta=45^{\circ}$ and $\beta=60^{\circ}$. By changing $\beta$ from $45^{\circ}$ to $60^{\circ}$, an earlier transition from laminar to turbulent flow was observed. Furthermore, from the results of flow distribution and surface temperature measurements, the authors found that the flow structure in a chevron corrugation PHE is always random, erratic and fully mixed with cross-streamline movements, 
even at low Reynolds number Re.

Dović and Švaić [24] carried out a number of visualization tests on two corrugated channels with $\beta=28^{\circ}$ and $61^{\circ}$ to analyze the influence of different geometric parameters on the channel thermal-hydraulic performance. The visualization results indicate that two flow components occurred simultaneously in both test channels. The flows in the $\beta=28^{\circ}$ and $61^{\circ}$ channels are mainly dominant by criss-cross (furrow) and wavy longitudinal (zig-zag) patterns, respectively. The pronounced longitudinal flow patterns were also found at a lower $\gamma$. In general, plates with higher $\beta$ and $\lambda$ yield flow passages that are characterized by more intensive heat transfer and higher pressure drops. Based on the experimental data and developed mathematical model, Dović et al. [25] further derived the $\mathrm{Nu}$ and $f$ correlations, applicable for $\operatorname{Re}=2-10000, \beta=15-67^{\circ}$ and $\gamma=0.26-0.4$

Kanaris et al. [26] presented an optimal design of a PHE with angled triangular ondulations in a chevron pattern. A commercial computational fluid dynamics (CFD) code, previously validated by experimental work $[27,28]$ carried out in the authors' research group, was used for the calculation of the heat transfer rate and friction losses in the channel. The response surface methodology was used as a global optimization method and an objective function, defined as a linear trade-off between the heat transfer and pressure drop, was employed. The optimization results indicate that the optimal geometrical configuration ultimately aims to create secondary flows, which are dominant for intense flow inside the furrows due to the corrugation structure, and thereby increases flow separation and reattachment leading to heat transfer enhancement.

Khan et al. [29] presented an experimental investigation for single-phase flow in a commercial PHE with symmetric $30^{\circ} / 30^{\circ}, 60^{\circ} / 60^{\circ}$, and mixed $30^{\circ} / 60^{\circ}$ chevron angle plates. By comparing the area enlargement factor and the increase of $\mathrm{Nu}$, the authors stated that enhanced 
heat transfer of a chevron corrugation PHE is primarily attributed to the greater turbulence level rather than to the surface area enlargement.

Han et al. [30] numerically investigated the thermal-hydraulic characteristics of a singlephase turbulent flow in a chevron corrugation PHE. The authors adopted the shear-stress transport $\mathrm{k}-\omega$ model as the turbulence model, which were validated by comparison with the experimental results presented in Ref. [29]. An approximation-assisted optimization technique was used for the optimization of four design variables. This technique can reduce computation time considerably by means of incorporating meta-models or correlations that could represent the thermal-hydraulic performance of the PHEs. The optimization results in terms of Pareto front solutions suggest that $\eta$ and $\beta$ are the most influential geometric parameters. The designs with higher $\eta$ have the better thermal-hydraulic performance in terms of enhancing the heat transfer coefficient with a relatively small pressure drop penalty.

Lee and Lee [31,32] presented a set of numerical analyses to investigate the flow characteristics and thermal performance, as well as the shape optimization, in chevron type PHEs. Blomerius [33] performed large-eddy simulations of flow within one of the PHE representative cells, adopting time-dependent filtered Navier-Stokes equations. The validation of the numerical results was accomplished by comparing the numerical results with the results of experimental correlations reported by Muley and Manglik [34]. The results of flow characteristics indicate that the furrow flow was dominant for small $\beta$, while the streamwise component of the flow (zig-zag flow) became increasingly significant as $\beta$ increased. The authors also carried out the corrugation optimization using the micro-genetic algorithm (MGA). The optimization results demonstrate that the optimal points $\left(\beta=66.5^{\circ}\right.$ and $\left.\lambda / \mathrm{b}=2.73\right)$ are almost constant, regardless of the Reynolds number. 
Sarraf et al. [2] presented a detailed analysis with numerical simulations of the heat and mass transfer for single-phase flow in brazed PHEs with various $\beta$. The results demonstrate that two flow structure types are sensitive not only to the chevron angle, but also to the mass flow rate. These two types of flow structure largely coexist for $\mathrm{Re}=20-200$. The results further reveal that two categories of PHE hydraulic behavior depend on the $\beta$, and the transition between these two hydraulic behaviors occurs at $\beta$ around $60^{\circ}$.

Vafajoo et al. [35] investigated numerically turbulent flow for flue gas-air chevron type PHEs with two different $\beta$. A validated turbulence model [36], the realizable $\mathrm{k}-\varepsilon$ model, was utilized in the simulations. The simulation results suggest that channels with higher chevron angles led to higher turbulent intensities and larger peak velocities, causing enhanced heat transfer rates accompanied with higher pressure drops.

\subsubsection{Plate dimension parameters}

In addition to the above parameters, open literature studies included other parameters including corrugation shape, plate size, distance between plates $\mathrm{S}$, plate number $\mathrm{N}$ and corrugation arrangement.

Zhang and Che [37] numerically investigated the effect of the corrugation profile on the thermal-hydraulic performance of a cross-corrugated plate for optimal structure design. Besides sinusoidal wavy, which is the most commonly encountered shape in the literature, four other corrugation profiles including isosceles triangular, isosceles trapezoidal, rectangular and elliptic curves, were compared numerically for the optimal design. The low Reynolds number k- $\varepsilon$ model [38] was adopted and was validated by comparing with the experimental results in Ref. [19]. Flow field simulations indicate that the corrugation profile, along with $\operatorname{Re}$ and $\beta$, are the major factors influencing the swirling flow pattern. For low Re, both the intensity and complexity of the swirling 
flow change greatly with the corrugation profile, while for high Re the change of the corrugation profile seems to make little difference. Maximum PEC occurred in the elliptic channel, while the minimum appeared in the trapezoidal channel.

Gulenoglu et al. [39] presented an experimental investigation of thermal and hydraulic characteristics of three different plate geometries. Two of them had the same geometrical parameters except for the $\mathrm{L}_{p}$, while the rest had larger dimensions. The experimental results suggest that the thermal and hydraulic characteristics enhance with decreasing plate size. With increasing port diameter and effective plate area, the flow velocity and uniformity at the end channels decrease.

Yang et al. [40] compared a set of brazed PHEs with different geometrical parameters. The experimental results suggest that $\beta$ is the most influential parameter. Generally, the single-phase heat transfer is enhanced with the increase of this angle. Moreover, geometric dimensions play a role in determining heat transfer characteristics. However, the PHEs with large/small dimensions do not necessarily lead to good/poor heat transfer performance. The geometric dimensions affect heat transfer in collaboration with $\beta$.

Faizal and Ahmed [41] performed an experimental study on a chevron corrugation PHE for small temperature difference applications with varied distance between plates $(\mathrm{S}=6 \mathrm{~mm}, 9 \mathrm{~mm}$, and $12 \mathrm{~mm}$ ). The PHE with $\mathrm{S}=6 \mathrm{~mm}$ exhibited the best thermal performance due to the effective heat transfer and higher thermal length even though the pressure losses were the highest.

Torii et al. $[42,43]$ investigated experimentally the heat transfer and pressure drop in a flow channel model of PHEs with different arrangements of corrugations, aiming to improve heat transfer performance and to attenuate pressure drops in PHEs. The study employed two types of re-arranged corrugations, denoted as separate chevron and plover patterns, respectively. 
Experimental results indicate that the overall heat transfer coefficient and pressure drop of the normal chevron corrugation plate is the highest compared with those of the two re-arranged samples. However, the separate chevron plate showed the best thermal-hydraulic performance among the three types of plates.

Table 1 Summary of experimental (E) and numerical (N) works related to parametric studies/analysis of chevron corrugation PHEs under single-phase flow conditions.

\begin{tabular}{|c|c|c|c|c|}
\hline Authors & Parameter & $\operatorname{Re}$ & Method & Key finding(s) \\
\hline $\begin{array}{l}\text { Focke et al. } \\
{[18,19]}\end{array}$ & $\begin{array}{l}\beta=0^{\circ}, 30^{\circ}, 45^{\circ} \\
60^{\circ}, 72^{\circ}, 80^{\circ} \text { and } \\
90^{\circ}\end{array}$ & $\begin{array}{l}100- \\
500\end{array}$ & $\mathrm{E}$ & $\begin{array}{l}\text { The maximum } f \text { and } j \text { occur at } \beta=80^{\circ} \text {. } \\
\text { Increasing } \beta \text { leads to a much larger } \\
\text { increase in } f \text { compared with that of heat } \\
\text { transfer, i.e. as } \beta \text { changes from } 30^{\circ} \text { to } \\
80^{\circ} \text { and } \operatorname{Re}=500, f \text { and } j \text { increase by } \\
2.5 \text { and } 18 \text { times, respectively. } \\
\text { - } \operatorname{Re}_{c r i}=10-500 \text {. }\end{array}$ \\
\hline $\begin{array}{l}\text { Manglik et al. } \\
{[20,21]}\end{array}$ & $\begin{array}{l}\beta=30^{\circ} / 30^{\circ}, \\
30^{\circ} / 60^{\circ} \text { and } \\
60^{\circ} / 60^{\circ} ; \gamma=0.56\end{array}$ & $2-6000$ & $\mathrm{E}$ & $\begin{array}{l}\text { - For } \beta=60^{\circ} \text {, the PHE has a } 3 \text { times } \\
\text { higher Nu and a } 6.6 \text { times higher } f \\
\text { compared with a flat PHE. } \\
\text { - The highest PEC is } 2.9 \text { as } \beta=30^{\circ} \text {. } \\
\text { - } \operatorname{Re}_{c r i} \approx 500 .\end{array}$ \\
\hline $\begin{array}{l}\text { Gaiser and } \\
\text { Kottke [44] }\end{array}$ & $\gamma=0.07-0.5$ & $\begin{array}{l}500- \\
10000\end{array}$ & $\mathrm{E}$ & - $\quad \mathrm{Nu}$ and $f$ increase with $\gamma$. \\
\hline $\begin{array}{l}\text { Hessami et al. } \\
{[22,23]}\end{array}$ & $\beta=45^{\circ}$ and $60^{\circ}$ & $\begin{array}{l}300- \\
1799\end{array}$ & $\mathrm{E}$ & $\begin{array}{l}\text { - As } \beta \text { changes from } 45^{\circ} \text { to } 60^{\circ}, \mathrm{Nu} \text { and } f \\
\text { increase by } 1.5-2 \text { times. } \\
\text { - } \beta=45^{\circ}, \operatorname{Re}_{c r i}=600-1300 ; \beta=60^{\circ}, \\
\operatorname{Re}_{c r i}=450-900 .\end{array}$ \\
\hline $\begin{array}{l}\text { Blomerius et } \\
\text { al. [33] }\end{array}$ & $\begin{array}{l}\gamma=0.05,0.056 \\
\text { and } 0.071\end{array}$ & $\begin{array}{l}150- \\
2000\end{array}$ & $\mathrm{~N}$ & $\begin{array}{l}\text { - For } \operatorname{Re}>1000, \mathrm{Nu} \text { and } f \text { are nearly } \\
\text { independent of } \gamma \text {. } \\
\text { - For } \operatorname{Re}<1000, \mathrm{Nu} \text { and } f \text { increase with } \\
\text { increase of } \gamma \text {, and } \mathrm{Nu} \text { and } f \text { increase by } \\
\text { about } 7 \% \text { and } 17 \% \text {. }\end{array}$ \\
\hline Lee et al. [45] & $\begin{array}{l}\beta=15^{\circ}, 30^{\circ} \text { and } \\
45^{\circ} ; \gamma=0.067 \\
0.089 \text { and } 0.134\end{array}$ & $\begin{array}{l}300- \\
9000\end{array}$ & $\mathrm{E}$ & $\begin{array}{l}\text { - Nu increases with } \beta \text { in the turbulent } \\
\text { regime. } \\
\text { - Nu does not change apparently with } \gamma \text {. }\end{array}$ \\
\hline Lin et al. [46] & $\beta=30^{\circ}$ and $45^{\circ}$ & $\begin{array}{l}300- \\
7000\end{array}$ & $\mathrm{E}$ & $\begin{array}{l}\text { - Using the Buckingham Pi theorem, it is } \\
\text { shown that } \mathrm{Nu} \text { is determined primarily } \\
\text { by Re and } \beta \text {. } \\
\text { - Nu increases by } 25 \% \text { as } \beta \text { increases } \\
\text { from } 30^{\circ} \text { to } 45^{\circ} \text {. }\end{array}$ \\
\hline $\begin{array}{l}\text { Dović and } \\
\text { Švaić [24] }\end{array}$ & $\gamma=0.27-0.5$ & $\begin{array}{l}0.1- \\
250\end{array}$ & $\mathrm{E}$ & $\begin{array}{l}\text { - } \mathrm{h} \text { and } \Delta \mathrm{P} \text { increase with } \gamma \text {. } \\
\text { - } \mathrm{h} \text { increases by } 30 \% \text { as } \gamma \text { changes from } \\
0.27 \text { to } 0.5 \text {. }\end{array}$ \\
\hline $\begin{array}{l}\text { Kanaris et al. } \\
\text { [26] }\end{array}$ & $\begin{array}{l}\beta=25^{\circ}, 50^{\circ}, 75^{\circ} \\
\gamma=0.05,0.225 \\
0.4 ; \text { W/L and D }\end{array}$ & $\begin{array}{l}500- \\
6000\end{array}$ & $\mathrm{~N}$ & $\begin{array}{l}\text { - Thermal-hydraulic performance } \\
\text { improves as the } S \text { and } W / L \text { decrease } \\
\text { and } \beta \text { increases. }\end{array}$ \\
\hline Khan et al. & $\beta=30^{\circ} / 30^{\circ}$ & $500-$ & E & - $\mathrm{Nu}$ increases with $\beta$ and increases \\
\hline
\end{tabular}




\begin{tabular}{|c|c|c|c|c|}
\hline [29] & $\begin{array}{l}30^{\circ} / 60^{\circ} \text { and } \\
60^{\circ} / 60^{\circ}\end{array}$ & 2500 & & $\begin{array}{l}\text { linearly with Re. } \\
\text { Nu increases by about } 2.8 \text { times as } \beta \\
\text { changes from } 30^{\circ} \text { to } 60^{\circ} \text {. }\end{array}$ \\
\hline $\begin{array}{l}\text { Wang et al. } \\
\text { [47] }\end{array}$ & $\begin{array}{l}\beta=30^{\circ}-80^{\circ} \\
\lambda / \mathrm{b}=2-5\end{array}$ & $\begin{array}{l}2500- \\
25000\end{array}$ & $\mathrm{~N}$ & $\begin{array}{l}\text { - Thermal performance can be improved } \\
\text { by increasing } \beta \text { and } \lambda / \mathrm{b} \text {. }\end{array}$ \\
\hline $\begin{array}{l}\text { Wang et al. } \\
\text { [48] }\end{array}$ & $\beta=30^{\circ}$ and $60^{\circ}$ & $\begin{array}{l}450- \\
6700\end{array}$ & $\mathrm{E}$ & $\begin{array}{l}\text { - } \mathrm{Nu} \text { and } f \text { of } \beta=60^{\circ} \mathrm{PHE} \text { are } 49-86 \% \\
\text { higher and 5.5-6 times higher than } \\
\text { those of } \beta=30^{\circ} \text {. } \\
\text { - } \beta=30^{\circ}, \operatorname{Re}_{c r i} \approx 974 ; \beta=60^{\circ}, \operatorname{Re}_{c r i} \\
\approx 1284 .\end{array}$ \\
\hline Guo et al. [49] & $\lambda=7-10 \mathrm{~mm}$ & $\begin{array}{l}500- \\
6000\end{array}$ & $\mathrm{~N}$ & $\begin{array}{l}\text { - } \quad f \text { increases with } \lambda . \\
\text { - } \quad \text { Nu has the highest value at } \lambda=9 \mathrm{~mm} \text {. } \\
\text { - The highest value of PEC } \approx 4.8 \text { occurs } \\
\text { at } \lambda=9 \mathrm{~mm} \text {. }\end{array}$ \\
\hline $\begin{array}{l}\text { Shaji and Das } \\
\text { [50] }\end{array}$ & $\begin{array}{l}\beta=30^{\circ} / 30^{\circ}, \\
30^{\circ} / 60^{\circ} \text { and } \\
60^{\circ} / 60^{\circ}\end{array}$ & $\begin{array}{l}900- \\
7800\end{array}$ & $\mathrm{E}$ & $\begin{array}{l}\text { - } f \text { and } \mathrm{Nu} \text { increase with } \beta \text {. } \\
\text { - Nu and } f \text { increase by about } 67 \% \text { and } \\
180 \% \text {, respectively, as } \beta \text { increases } \\
\text { from } 30^{\circ} \text { to } 60^{\circ} \text {. }\end{array}$ \\
\hline $\begin{array}{l}\text { Zhao et al. } \\
\text { [51] }\end{array}$ & $\mathrm{b}=2-6 \mathrm{~mm}$ & - & $\mathrm{N}$ & $\begin{array}{l}\text { - With the increase of } \mathrm{b}, \mathrm{Nu} \text { increases } \\
\text { while } f \text { decreases. }\end{array}$ \\
\hline Han et al. [30] & $\beta, b, \lambda(\eta)$ & $\begin{array}{l}500- \\
15000\end{array}$ & $\mathrm{~N}$ & $\begin{array}{l}\text { - Optimal results suggest highest } \eta \text { and } \\
\beta \text { increase with maximum } h \text {. }\end{array}$ \\
\hline $\begin{array}{l}\text { Hajabdollahi } \\
\text { et al. [52] }\end{array}$ & $\begin{array}{l}\beta, b, \lambda, L, W \text { and } \\
\mathrm{N}\end{array}$ & - & $\mathrm{N}$ & $\begin{array}{l}\text { PHE effectiveness is proportional to } \\
\text { the ratio of } b / \lambda \text { in the optimum } \\
\text { situation. }\end{array}$ \\
\hline $\begin{array}{l}\text { Lee and Lee } \\
{[31,32]}\end{array}$ & $\begin{array}{l}15^{\circ} \leq \beta \leq 75^{\circ} \\
0.23 \leq \gamma \leq 0.5\end{array}$ & $\begin{array}{l}200- \\
5000\end{array}$ & $\mathrm{~N}$ & $\begin{array}{l}\text { - } \quad \mathrm{j} \text { and } \mathrm{f} \text { increase with } \beta \text { and } \gamma \text {. } \\
\text { - } \mathrm{j} \text { increases by about } 60 \% \text { and } 92 \% \\
\text { and } f \text { increases by about } 109 \% \text { and } \\
273 \% \text {, as } \beta \text { increases from } 30^{\circ} \text { to } 60^{\circ} \\
\text { and } \gamma \text { increases from } 0.23 \text { to } 0.5 \text {. }\end{array}$ \\
\hline $\begin{array}{l}\text { Zhao et al. } \\
\text { [53] }\end{array}$ & $\beta=30^{\circ}-80^{\circ}$ & - & $\mathrm{N}$ & $\begin{array}{l}\text { - } \beta \text { should be chosen from } 60^{\circ} \text { to } 70^{\circ} \text { as } \\
\text { a tradeoff between } h \text { and } \Delta \mathrm{P} \text {. }\end{array}$ \\
\hline $\begin{array}{l}\text { Sarraf et al. } \\
{[2]}\end{array}$ & $\begin{array}{l}\beta=30^{\circ}, 45^{\circ}, 55^{\circ} \\
65^{\circ} \text { and } 70^{\circ}\end{array}$ & $1-2500$ & $\mathrm{~N}$ & $\begin{array}{l}\text { - } f \text { and } \mathrm{h} \text { increases with the increase of } \beta \text {. } \\
\text { The mass transferred by furrow flow } \\
\text { (introduced in Section } 4.1 .1 \text { ) change } \\
\text { from } 12-50 \% \text { to } 80-96 \% \text { as } \beta \\
\text { increases from } 30^{\circ} \text { to } 70^{\circ} \text {. }\end{array}$ \\
\hline Kan et al. [54] & $\begin{array}{l}\beta=30^{\circ}, 45^{\circ} \text { and } \\
65^{\circ}\end{array}$ & - & $\mathrm{N}$ & $\begin{array}{l}\text { At } \operatorname{Re} \approx 13000, \text { the heat transfer } \\
\text { increase and effectiveness of PHE } \\
\text { decrease with the increase of } \beta \text {. }\end{array}$ \\
\hline $\begin{array}{l}\text { Krishna et al. } \\
{[55]}\end{array}$ & $\begin{array}{l}\beta=30^{\circ}, 40^{\circ} \text { and } \\
50^{\circ}\end{array}$ & $\begin{array}{l}100- \\
2500\end{array}$ & $\mathrm{E}$ & $\begin{array}{l}\text { - Nu increases with } \beta \text {. } \\
\text { ru increases by } 15 \% \text { and } 30 \% \text {, } \\
\text { respectively, for the increase of } \beta \text { by } \\
30^{\circ} \text { to } 40^{\circ} \text { and } 40^{\circ} \text { to } 50^{\circ} \text {. }\end{array}$ \\
\hline $\begin{array}{l}\text { Vafajoo et al. } \\
\text { [35] }\end{array}$ & $\beta=29^{\circ}$ and $85^{\circ}$ & $\begin{array}{l}10000- \\
50000\end{array}$ & $\mathrm{~N}$ & $\begin{array}{l}\text { - } \quad \mathrm{Nu} \text { and } f \text { increase with } \beta \text {. } \\
\text { - As } \beta \text { increases, velocity vectors change } \\
\text { more significantly. }\end{array}$ \\
\hline $\begin{array}{l}\text { Kilıç and İpek } \\
{[56]}\end{array}$ & $\beta=30^{\circ}$ and $60^{\circ}$ & $\begin{array}{l}800- \\
2300\end{array}$ & $\mathrm{E}$ & $\begin{array}{l}\text { A channel with } \beta=60^{\circ} \text { has the higher } \\
\text { effectiveness and the heat transfer rate. }\end{array}$ \\
\hline $\begin{array}{l}\text { Zhang and } \\
\text { Che [37] }\end{array}$ & Corrugation shape & $\begin{array}{l}1000- \\
10000\end{array}$ & $\mathrm{~N}$ & $\begin{array}{l}\text { - The cross-corrugated plates have PECs } \\
\text { ranging from } 1.1 \text { to } 3.1 \text { times compared }\end{array}$ \\
\hline
\end{tabular}




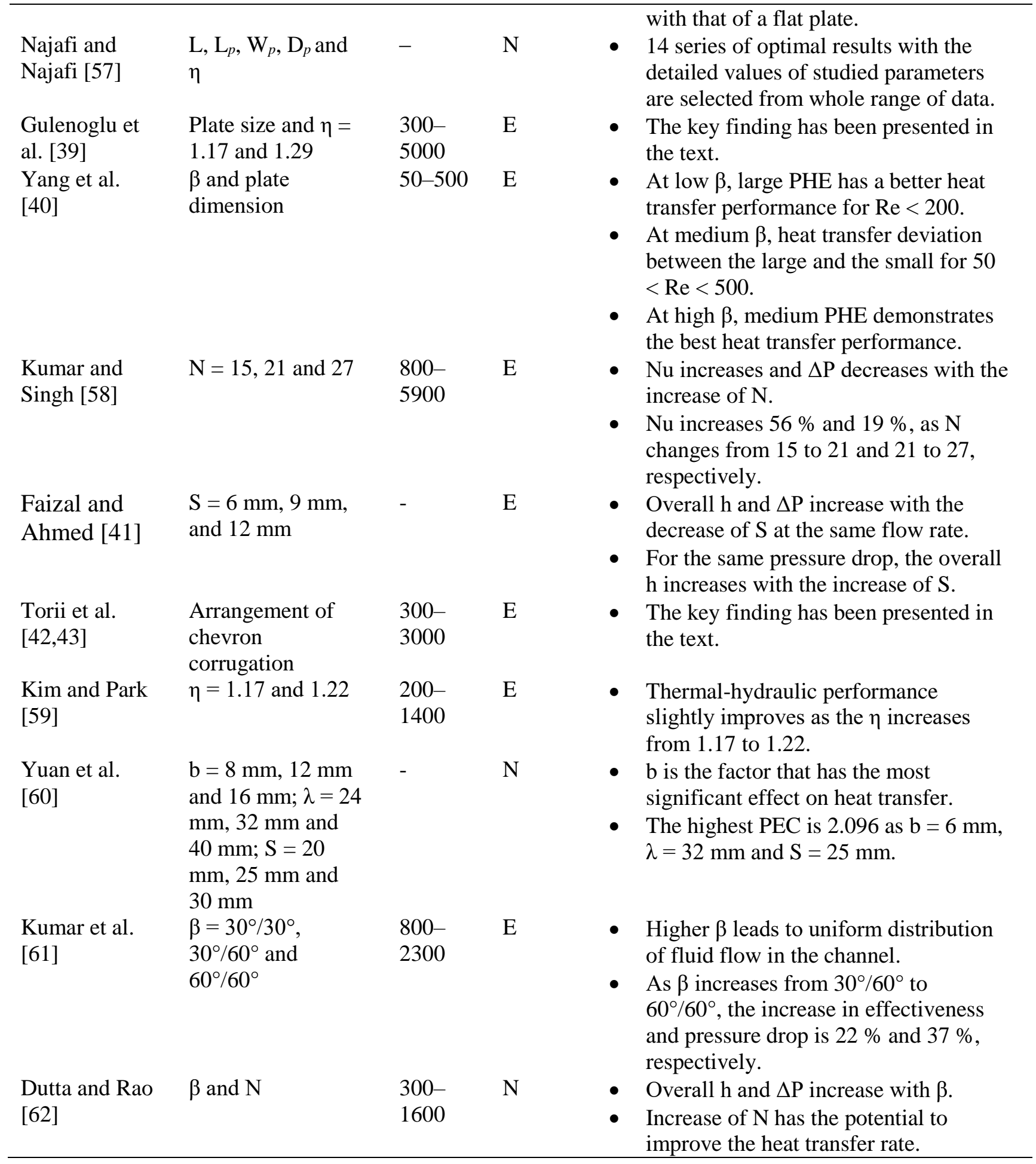

- $\mathrm{Re}_{\text {cri: }}$ critical Reynolds number, indicating the transition from laminar to turbulent flow

- h: heat transfer coefficient

- $\Delta \mathrm{P}$ : frictional pressure drop

\subsection{Effect of geometrical parameters on the two-phase heat transfer}

In the area of the two-phase heat transfer, only a few experimental works are available; these 
are summarized in Table 2.No numerical studies on two-phase heat transfer in PHEs are available, which, most likely, can be attributed to the challenges associated with the modelling the two-phase flow in complex PHE channels. Besides, the existing research works only investigated the influence of the chevron angle on two-phase heat transfer, while effects of other geometries such as corrugation pitch and height not were addressed.

Han et al. $[63,64]$ performed flow boiling and condensation experiments with the refrigerants R410a and R22 in PHEs with different chevron angles $\left(45^{\circ}, 55^{\circ}\right.$ and $\left.70^{\circ}\right)$. Both the heat transfer coefficient and pressure drop in the flow boiling and condensation increase with the increase in $\beta$. The results demonstrate that larger $\beta$ creates stronger turbulence and more abrupt changes of the flow path inside the PHEs, which intensify the heat transfer.

Würfel and Ostrowski [65] presented an experimental investigation of the condensation in the channels of corrugated plates with three chevron angle configurations $30^{\circ} / 30^{\circ}, 30^{\circ} / 60^{\circ}$ and $60^{\circ} / 60^{\circ}$, finding that heat transfer coefficients and friction factors increase with the increase of $\beta$, and the heat transfer coefficients increase 3-4 times as $\beta$ changes from $30^{\circ} / 30^{\circ}$ to $60^{\circ} / 60^{\circ}$. The results indicate that a plate combination with plates of different chevron angles $\left(30^{\circ} / 60^{\circ}\right)$ proves to be an optimal solution to maximize the thermal-hydraulic performance.

Djordjevic and Kabelac [66] studied experimentally the flow boiling of ammonia and R134a in chevron PHEs with $\beta=27^{\circ}$ and $63^{\circ}$, by using measurements of quasi-local heat transfer coefficients along the plate. The results indicate that both convective and nucleate boiling mechanisms exist in the heat transfer process. Further, their results indicate that a low chevron angle plate is beneficial for evaporation and suppression of the dryout region.

Hayes et al. [67,68] presented two experimental investigations of carbon dioxide condensation with three different PHEs, containing low profile $\left(30^{\circ} / 30^{\circ}\right.$ plates $)$, high profile 
$\left(63^{\circ} / 63^{\circ}\right.$ plates $)$ and mixed profile $\left(63^{\circ} / 30^{\circ}\right.$ plates $)$. The experimental results suggest that the heat transfer coefficients and friction factors of the high profile plates are higher than those of the mixed and low profile plates. The authors argued that low profile plates exhibit heat transfer behavior that was more scattered than that of the other two profile plates. The flow in the plate with low $\beta$ might be experiencing more of laminar or transitional flow regimes, while the other two plates were, most likely, transferring heat in the turbulent regime.

Huang et al. [69] investigated experimentally the heat transfer and pressure drop characteristics of industrial PHEs used as liquid over-feed evaporators. The tests were carried out with three different PHEs $\left(\beta=60^{\circ} / 60^{\circ}, 20^{\circ} / 60^{\circ}\right.$ and $\left.28^{\circ} / 28^{\circ}\right)$ using the fluids R134a and R507A. The heat transfer data suggests that a nucleate boiling-dominant process is present in the evaporators, for which the heat transfer coefficient shows a strong dependence on the heat flux, and a weak dependence on the refrigerant mass flux, vapor quality, and the chevron angle.

Khan et al. [70] presented an experimental investigation of heat transfer and pressure drop during steady state evaporation of ammonia in a commercial PHE with an asymmetric $30^{\circ} / 60^{\circ}$ chevron plate configuration. This mixed plate configuration $\left(\beta=30^{\circ} / 60^{\circ}\right)$ was compared with the authors' previous studies using the same heat exchanger with symmetric plate configurations $(\beta=$ $30^{\circ} / 30^{\circ}$ and $60^{\circ} / 60^{\circ}$ ) [71,72]. The comparison demonstrates that both heat transfer coefficients and pressure drop increase with the increase of chevron angle. The dryout in the evaporator was suppressed as the chevron angle decreased under the same heat flux.

Müller and Kabelac [73] investigated experimentally the two-phase heat transfer and pressure drop during the condensation in PHEs with $\beta=27^{\circ}$ and $63^{\circ}$. The results indicate that the heat transfer coefficients and pressure drops increase $3-4$ times as $\beta$ changes from $27^{\circ}$ to $63^{\circ}$.

Table 2 Summary of experimental studies of two-phase heat transfer in chevron corrugation PHEs. 


\begin{tabular}{|c|c|c|c|c|}
\hline Authors & $\begin{array}{l}\text { Heat transfer } \\
\text { characteristic }\end{array}$ & Parameter & Working fluids & $\mathrm{T}_{\mathrm{sat}}$ \\
\hline Han et al. [63] & $\begin{array}{l}\text { Convective boiling- } \\
\text { dominant }\end{array}$ & $\begin{array}{l}\beta=45^{\circ}, 55^{\circ} \text { and } \\
70^{\circ}\end{array}$ & R410A and R22 & $\begin{array}{l}5^{\circ} \mathrm{C}, 10^{\circ} \mathrm{C} \\
\text { and } 15^{\circ} \mathrm{C}\end{array}$ \\
\hline Han et al. [64] & Condensation & $\begin{array}{l}\beta=45^{\circ}, 55^{\circ} \text { and } \\
70^{\circ}\end{array}$ & $\mathrm{R} 410 \mathrm{~A}$ and R22 & $\begin{array}{l}20^{\circ} \mathrm{C} \text { and } \\
30^{\circ} \mathrm{C}\end{array}$ \\
\hline $\begin{array}{l}\text { Würfel and } \\
\text { Ostrowski [65] }\end{array}$ & $\begin{array}{l}\text { Shear-controlled } \\
\text { condensation }\end{array}$ & $\begin{array}{l}\beta=30^{\circ} / 30^{\circ}, \\
30^{\circ} / 60^{\circ} \text { and } 30^{\circ} / 30^{\circ}\end{array}$ & $\begin{array}{l}\text { water and n- } \\
\text { heptane }\end{array}$ & $\approx 100^{\circ} \mathrm{C}$ \\
\hline $\begin{array}{l}\text { Djordjevic and } \\
\text { Kabelac [66] }\end{array}$ & $\begin{array}{l}\text { Convective and } \\
\text { nucleate boiling }\end{array}$ & $\beta=27^{\circ}$ and $63^{\circ}$ & $\begin{array}{l}\text { Ammonia and } \\
\mathrm{R} 134 \mathrm{a}\end{array}$ & $-8^{\circ} \mathrm{C}$ to $10^{\circ} \mathrm{C}$ \\
\hline $\begin{array}{l}\text { Hayes et al. } \\
{[67,68]}\end{array}$ & $\begin{array}{l}\text { Shear-controlled } \\
\text { condensation }\end{array}$ & $\begin{array}{l}\beta=63^{\circ} / 63^{\circ}, \\
30^{\circ} / 63^{\circ} \text { and } 30^{\circ} / 30^{\circ}\end{array}$ & $\mathrm{CO}_{2}$ & $\begin{array}{l}-34.4^{\circ} \mathrm{C} \text { to } \\
17.8^{\circ} \mathrm{C}\end{array}$ \\
\hline Huang et al. [69] & $\begin{array}{l}\text { Nucleate boiling- } \\
\text { dominant }\end{array}$ & $\begin{array}{l}\beta=60^{\circ} / 60^{\circ}, \\
28^{\circ} / 60^{\circ} \text { and } 28^{\circ} / 28^{\circ}\end{array}$ & $\begin{array}{l}\text { R134a and } \\
\text { R507A }\end{array}$ & $\begin{array}{l}5.9^{\circ} \mathrm{C} \text { to } \\
13{ }^{\circ} \mathrm{C}\end{array}$ \\
\hline Khan et al. [70] & $\begin{array}{l}\text { Convective boiling- } \\
\text { dominant }\end{array}$ & $\begin{array}{l}\beta=60^{\circ} / 60^{\circ}, \\
30^{\circ} / 60^{\circ} \text { and } 30^{\circ} / 30^{\circ}\end{array}$ & Ammonia & $\begin{array}{l}-25^{\circ} \mathrm{C} \text { to }- \\
2{ }^{\circ} \mathrm{C}\end{array}$ \\
\hline $\begin{array}{l}\text { Müller and } \\
\text { Kabelac [73] }\end{array}$ & Condensation & $\beta=27^{\circ}$ and $63^{\circ}$ & $\begin{array}{l}\text { Water and } \\
\text { R134a }\end{array}$ & - \\
\hline Imran et al. [74] & $\begin{array}{l}\text { Nucleate boiling- } \\
\text { dominant }\end{array}$ & $\beta=45^{\circ}$ and $60^{\circ}$ & R245fa & $\begin{array}{l}62.7^{\circ} \mathrm{C} \text { and } \\
69.4^{\circ} \mathrm{C}\end{array}$ \\
\hline Kim et al. [75] & $\begin{array}{l}\text { Convective and } \\
\text { nucleate boiling }\end{array}$ & $\beta=30^{\circ}$ and $60^{\circ}$ & $\begin{array}{l}\text { R134a and } \\
\text { R1234ze(E) }\end{array}$ & $\begin{array}{l}5^{\circ} \mathrm{C}, 10^{\circ} \mathrm{C} \\
\text { and } 15^{\circ} \mathrm{C}\end{array}$ \\
\hline Miyata et al. [76] & Condensation & $\begin{array}{l}\beta=30^{\circ}, 47.5^{\circ} \text { and } \\
60^{\circ}\end{array}$ & $\begin{array}{l}\text { R134a and } \\
\text { R1234ze(E) }\end{array}$ & $\begin{array}{l}55^{\circ} \mathrm{C} \text { to } \\
126^{\circ} \mathrm{C}\end{array}$ \\
\hline
\end{tabular}

- $\mathrm{T}_{\text {sat: }}$ saturation temperature in boiling or condensation process

\section{Enhancement techniques in plate heat exchangers}

Various research groups have investigated the use of enhancement techniques in PHEs, especially for the single-phase heat transfer. Specifically, most of the studies adopted passive techniques, mainly focusing on passive surface techniques and nanofluids. The percentages of the studies, in total covering 66 journal and conference papers published from 1999 to 2018 , focusing on heat transfer patterns, enhancement techniques and research methods are presented in Figure 4. The studies also evaluate the corresponding enhanced heat transfer performance, as well as the penalty of pressure drop. In this regard, the following subsections present an overview of the use of heat transfer enhancement techniques in PHEs based on the passive surface techniques, the use of nanofluids, and other enhancement techniques (the active techniques and other passive techniques different from passive surface techniques and nanofluids). 


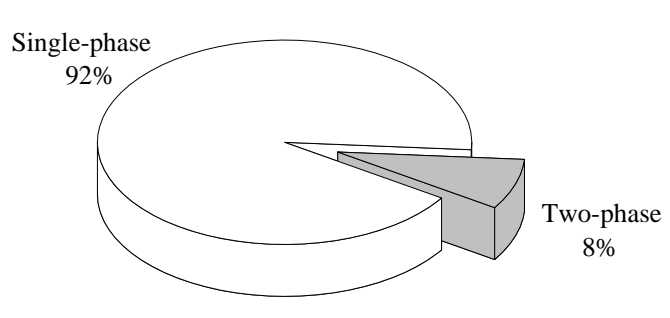

(a)

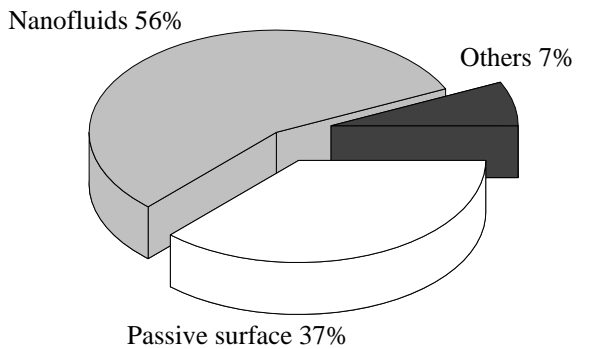

(b)

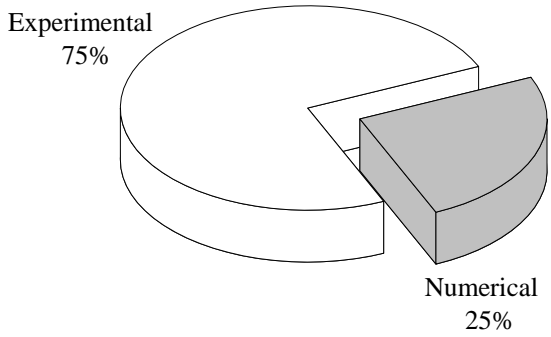

(c)

Figure 4 The percentages of the studies related to the heat transfer enhancement in (a) single-phase and two-phase and (b) enhancement techniques.

\subsection{Passive surface enhancement techniques}

The studies mentioned in Sections 3.1.1 and 3.1.2 refer exclusively to a surface that either has a different structure from the conventional chevron corrugation shown in Figure 2, or is a chevroncorrugated plate with a rough surface.

\subsubsection{Single-phase enhancement}

Diverse passive surface shape/configurations have been proposed and applied to the singlephase heat transfer in PHEs for heat transfer enhancement; the relevant research works are summarized in Table 3. Generally, these passive techniques imply that the plate surface is modified according to one of the following three categories: i) embossing surface, ii) secondary 
corrugated surface, or iii) roughened surface.

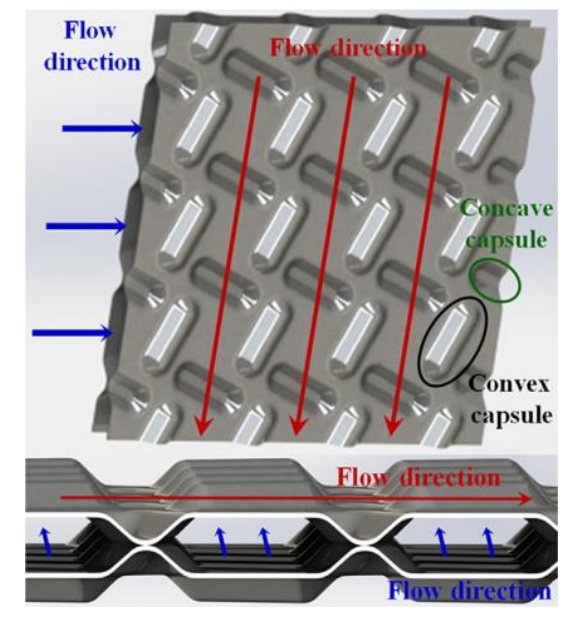

Figure 5 Schematics of a capsule-type PHE [77].

The first type of surface is characterized by various independent embossing arrayed on the plate, which has the effect similar to a finned plate. There are two types of an embossing surface for a single plate, concave and convex, with staggered arrangement. Figure 5 shows a diagram of a PHE with capsule-type embossing investigated by Zhang et al. [77]. This kind of capsule embossing structure has the advantages of less deposition and fouling, lower pressure loss and easy cleaning and maintenance, compared with the conventional chevron corrugation PHEs. The authors developed a capsule-type PHE, which the petroleum industry applies for use with high viscosity fluids. Numerical investigations covered single-phase flow and heat transfer in the plate channel, employing a shear-stress transport k- $\omega$ turbulent model. The numerical results indicate that the capsule-type PHE has the better thermal-hydraulic performance compared with a conventional chevron corrugation PHE.

Within the first type of surface, dimple-type embossing has been widely studied in Refs. [7882]. In particular, Du et al. [81] and Song et al. [82] developed a regular hexagon plate with dimple-type embossing for application in aerospace engineering. This regular hexagon PHE can 
even manipulate three flow currents to exchange heat at the same time. Their results indicate that the heat transfer and hydraulic performances of such novel PHEs are superior to those of a chevron corrugation PHE with $\beta=60^{\circ}$.

Jeong et al. [83] carried out a numerical analysis of the heat transfer and pressure drop characteristics of welded PHEs with three embossing types: chevron, elliptic and round. A CFD code using the standard k- $\varepsilon$ turbulence model was validated with measurements of a chevron corrugation embossing PHE. Numerical results demonstrate that the elliptic-type embossing plate has the best thermal-hydraulic performance among the three types of embossing PHEs for the same plate geometric and thermal conditions.

Durmuş et al. [84] presented an experimental investigation for three different PHEs (flat PHE, corrugated PHE and asterisk-type PHE). Figure 6 depicts the corrugated PHE and asterisk-type PHE. The test data showed that the corrugated PHE has the highest heat transfer rate, but also the largest friction factor. In order to evaluate the effectiveness of the PHEs, an exergy-based analytical method was introduced. A comparison of the exergy losses of three PHEs suggested that the corrugated PHE had the highest effectiveness.

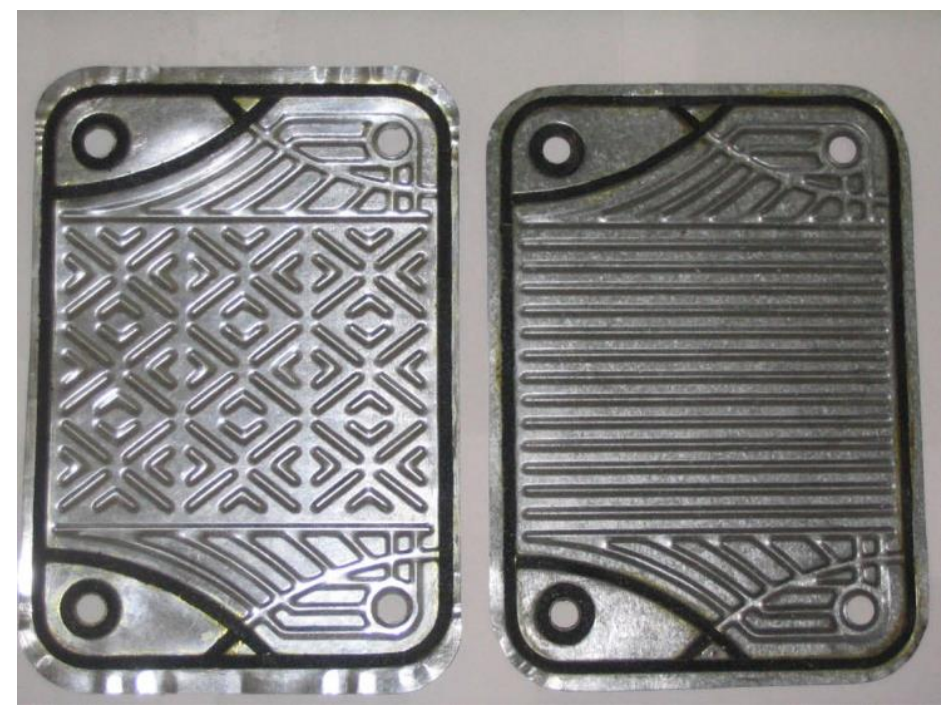


Figure 6 Photo of asterisk-type and corrugated plates [84].

In addition, previous works suggest that the bubble-type [85], horseshoe-type [86,87] and circular spot-type [88] embossing have the potential of either enhancing the thermal-hydraulic performance or improving the compactness of the heat exchanger.

The second type of surface consists of a secondary corrugated structure placed on the primary profile, where the conventional chevron corrugation usually acts as the primary profile.
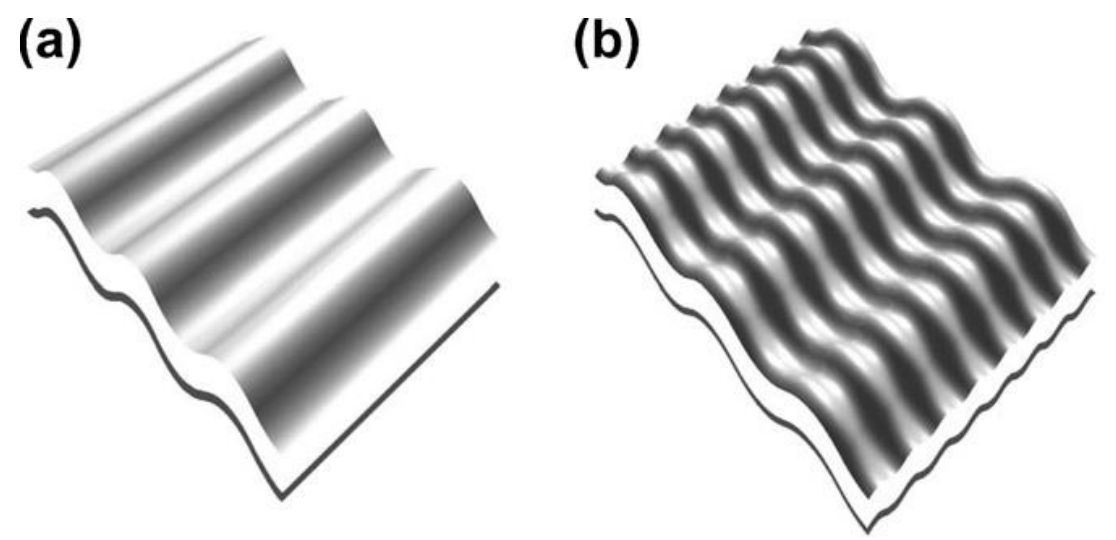

Figure 7 Diagrams of the plate surfaces (a) single-wave and (b) double-wave [89].

Kim et al. [89] presented an experimental study of cross-flow air-cooled PHEs, using manufactured single-wavy plates and double-wavy plates. As shown in Figure 7, the double-wavy plate refers to the additional corrugations pressed perpendicular to the single-waves. The experimental results suggest that the thermal-hydraulic performance of the double-wave PHE is desirable as an air-cooled PHE. However, the modification on the plate structure for a wider gap between the plates is still needed, in order to decrease the pressure drop in the PHE. 


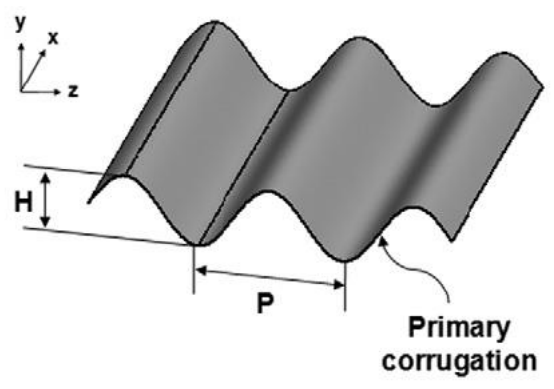

(a)

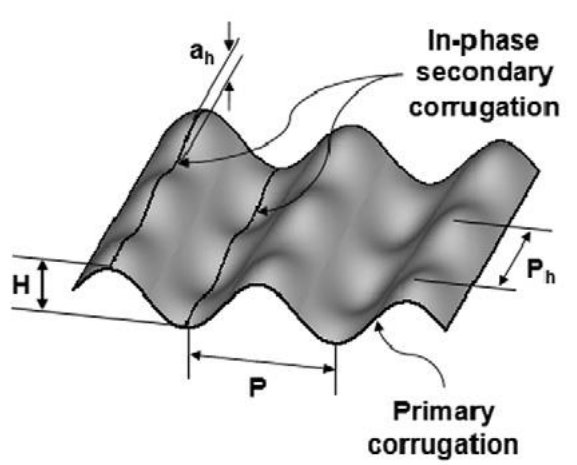

(c)

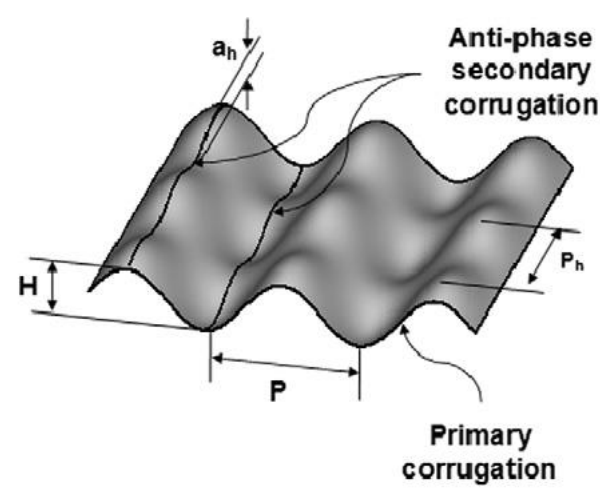

(b)

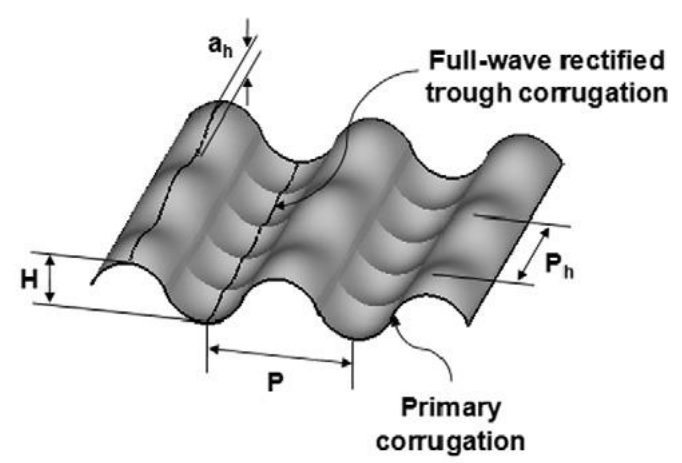

(d)

Figure 8 Configurations of four different primary surfaces with (a) conventional sinusoidal corrugation, (b) anti-phase secondary corrugation, (c) in-phase secondary corrugation and (d) fullwave rectified trough corrugation [90].

Doo et al. [90] modified the cross-corrugated primary surface by introducing three novel secondary corrugations, as illustrated in Figure 8 . The peak and trough of the sinusoidal plate surface were modified with anti-phase, in-phase and full-wave rectified trough corrugation, respectively, aiming at improving the performance of the PHEs for aeroengine intercooler applications. A validated CFD code predicted the performances of these modified configurations, and the numerical results indicate that anti-phase and full-wave rectified secondary corrugations have higher thermal-hydraulic perfromance than the conventional primary surface, demonstrating their potential in retrofitting PHEs. Subsequently, Doo et al. [91] performed a numerical 
optimization of the most promising configuration, the anti-phase secondary corrugation and used a new objective function to find the compromised trade-off between the volume goodness factor and the area goodness factor. The optimized anti-phase corrugation exhibited new flow structures such as flow separation, re-circulation and impingement, resulting in an additional enhancement in heat transfer. To further extend their research on the cross-corrugated PHE with novel secondary surface profiles, Lee et al. [92] tested experimentally a set of PHEs with diverse surface profiles and corrugation furrow shapes. A large amount of data in terms of thermal-hydraulic performance was derived, which is expected to be a useful reference for the design of more efficient and lightweight PHEs.

Luan et al. [93] investigated numerically a new PHE with compound corrugation, aiming to prevent the blockage of the flow path. The compound ondulated corrugations were formed by two curves in two different directions, which were named as transverse and longitudinal curves, respectively. Their numerical results indicate that the compound corrugation is able to reduce the flow resistance significantly compared with the conventional chevron corrugation. The paper presents a detailed discussion on the flow fields in the compound and chevron corrugations, aiming to identify the mechanisms of the reduction of the flow resistance. Subsequently, Cao et al. [94] optimized this compound corrugation PHE using high viscosity oil as the working fluid. The simulations indicate that the inclination angle between the transverse and longitudinal corrugations is a crucial parameter that influences the thermal-hydraulic performance significantly. Under low Re and high $\operatorname{Pr}(27<\operatorname{Re}<267$ and $372<\operatorname{Pr}<450)$, this novel PHE demonstrates better heat transfer and hydraulic performances compared with those of a chevron corrugation PHE.

The roughened surface type is a kind of roughened surface on the base of a smooth chevrontype corrugation, where different materials fabricate the roughness. 
Nilpueng and Wongwises [95] investigated experimentally the effect of surface roughness on the heat transfer coefficient and pressure drop of water flow in the PHEs. A surface roughness $\mathrm{R}$ ranging from $1.189 \mu \mathrm{m}$ to $3.312 \mu \mathrm{m}$ was created on the cold stream side by using a sand blasting machine with varied sand diameter sizes. Figure 9 shows the smooth and roughened plate surfaces. The experimental results indicate that the Nusselt number and friction factors increase with the increase of the roughness. The thermal-hydraulic performance increases with the roughness and decreases with the Reynolds number.

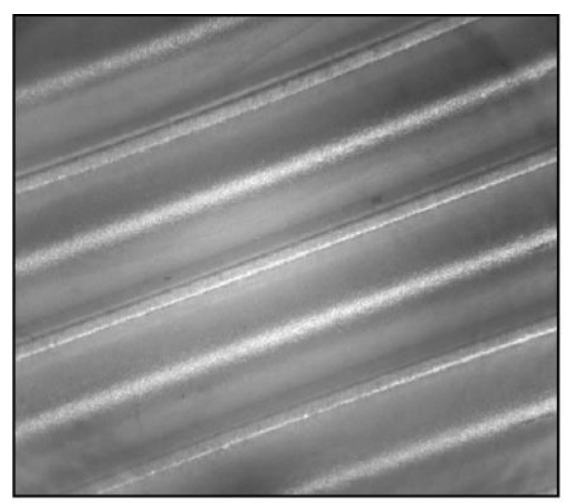

(a)

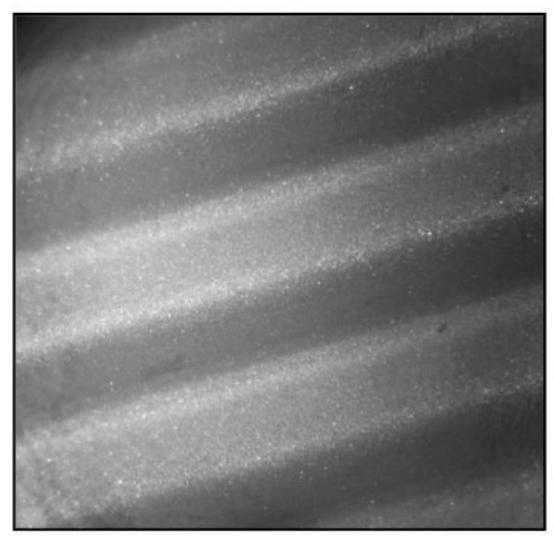

(c)

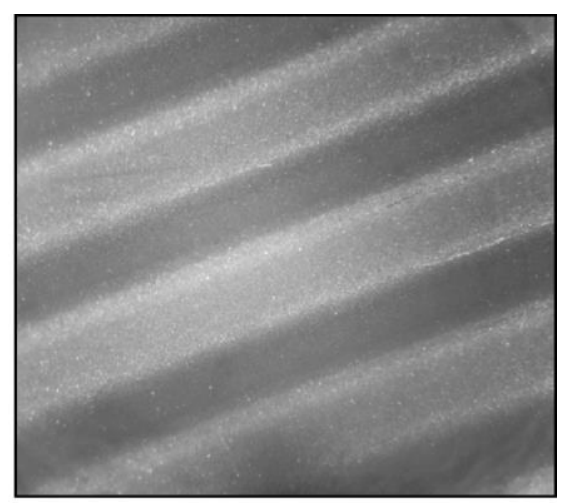

(b)

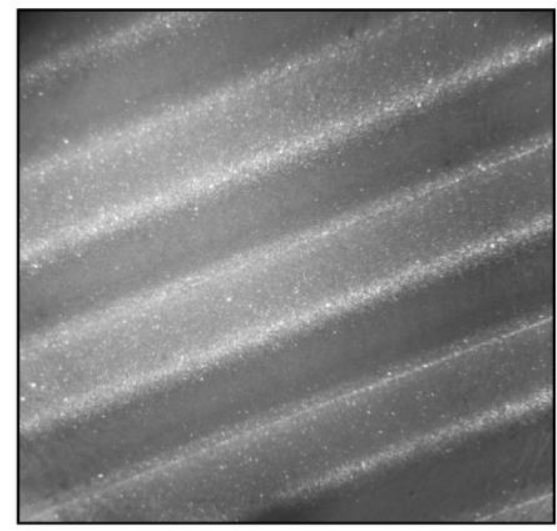

(d)

Figure 9 Photos of smooth and roughened plate surfaces, (a) $R=0.936 \mu \mathrm{m}$ (smooth surface), (b) $\mathrm{R}$ $=1.189 \mu \mathrm{m}$, (c) $\mathrm{R}=1.378 \mu \mathrm{m}$ and (d) $\mathrm{R}=3.312 \mu \mathrm{m}$ [95].

Wajs and Mikielewicz [96] proposed a new technique for increasing the surface roughness through abrasive blasting with the utilization of glass micro-beads. The paper introduces two 
roughness parameters $\mathrm{R}_{a}$ and $\mathrm{R}_{z}$ to characterize the roughened surface. $\mathrm{R}_{a}$ represents an average roughness along the plate, while $\mathrm{R}_{a}$ is an arithmetic average of the absolute heights of the five highest peaks and five deepest valleys. In the study, $\mathrm{R}_{a}$ and $\mathrm{R}_{z}$ were $2.8 \mu \mathrm{m}$ and $15.9 \mu \mathrm{m}$, respectively, which are 6 times and 5 times higher than those of a smooth plate surface. The authors conducted a series of experiments for the water-water case comparing a smooth PHE with the PHE with the modified surface. It was found that the overall heat transfer coefficient of the smooth PHE is higher than that of the modified one when the mass flux of the hot side reached its maximum. On the other hand, for the lowest mass flux, the opposite tendency was found. Subsequently, Wajs and Mikielewicz [97] employed a metallic porous microlayer rough surface with $\mathrm{R}_{a}=1.43 \mu \mathrm{m}$ and $\mathrm{R}_{z}=11.02 \mu \mathrm{m}$ for the water-ethanol single-phase convective heat transfer. The results suggest that the heat transfer coefficients of the modified PHE on the ethanol side (cold side) are higher than those of a smooth chevron corrugation PHE, while on the water side (hot side), the tendency is the opposite, which means the heat transfer enhancement could only be found on the cold side.

Table 3 Summary of the passive surface techniques in the single-phase heat transfer.

\begin{tabular}{|c|c|c|c|}
\hline Authors & Surface technique & Method & Key findings \\
\hline $\begin{array}{l}\text { Zhang et al. } \\
\text { [77] }\end{array}$ & $\begin{array}{l}\text { Capsule-type } \\
\text { embossing }\end{array}$ & $\mathrm{N}$ & $\begin{array}{l}\text { Capsule-type PHE has slightly higher } \mathrm{Nu} \\
\text { compared with a } \beta=60^{\circ} \text { chevron } \\
\text { corrugation PHE for Re }<3000 \text {. } \\
\text { Capsule-type PHE has the much lower } \\
\text { pressure drop compared with chevron } \\
\text { corrugation PHEs with } \beta=45^{\circ} \text { and } 60^{\circ} \text {. }\end{array}$ \\
\hline Li et al. [78] & Dimple-type embossing & $\mathrm{E}$ & $\begin{array}{l}\text { Dimple-type PHE has 10-30 \% higher heat } \\
\text { transfer rate than that of a chevron } \\
\text { corrugation PHE. } \\
\text { - The increase in heat transfer is more } \\
\text { significant at low Re. }\end{array}$ \\
\hline Ji et al. [79] & Dimple-type embossing & $\mathrm{E}$ & $\begin{array}{l}\text { - Heat transfer capability and flow resistance } \\
\text { of dimple-type PHE both increase } \\
\text { compared with a flat PHE. } \\
\text { - Nu increases by } 2-2.5 \text { times. }\end{array}$ \\
\hline $\begin{array}{l}\text { Alqutub et al. } \\
\text { [80] }\end{array}$ & Dimple-type embossing & $\mathrm{E}$ & $\begin{array}{l}\text { - Both the higher } \mathrm{Nu} \text { and } \mathrm{f} \text { were obtained by } \\
\text { the dimple-type PHE. } \\
\text { - Based on the flat PHE, dimple-type PHE }\end{array}$ \\
\hline
\end{tabular}




\begin{tabular}{|c|c|c|c|}
\hline $\begin{array}{l}\text { Cheng et al. } \\
{[81,82]}\end{array}$ & $\begin{array}{l}\text { Regular hexagon plate } \\
\text { with dimple-type } \\
\text { embossing }\end{array}$ & $E \& N$ & $\begin{array}{l}\text { has maximum PEC of } 1.5 \text { at } \mathrm{Re}=2300 \text {. } \\
\text { The better thermal-hydraulic performance } \\
\text { was obtained with regular hexagon PHE } \\
\text { compared with a chevron corrugation PHE. }\end{array}$ \\
\hline Jeong et al. [83] & $\begin{array}{l}\text { Chevron-, elliptic- and } \\
\text { round-type embossing }\end{array}$ & $\mathrm{N}$ & $\begin{array}{l}\text { - The elliptic-type embossing plate has the } \\
\text { best heat transfer performance. } \\
\text { - The chevron-type embossing plate has } \\
\text { much higher pressure drop than the other } \\
\text { two plates. }\end{array}$ \\
\hline $\begin{array}{l}\text { Durmuş et al. } \\
\text { [84] }\end{array}$ & $\begin{array}{l}\text { Flat, chevron } \\
\text { corrugation }\left(\beta=90^{\circ}\right) \\
\text { and asterisk-type plates }\end{array}$ & $\mathrm{E}$ & $\begin{array}{l}\text { - Chevron corrugation PHE has about } 17 \% \\
\text { and } 40 \% \text { higher Nu and } f \text { than the asterisk- } \\
\text { type PHE. } \\
\text { - } \triangle \mathrm{P} \text { in the chevron corrugation and asterisk- } \\
\text { type PHEs increase } 2.5 \text { and } 3.5 \text { times } \\
\text { according to the flat-type PHE. }\end{array}$ \\
\hline $\begin{array}{l}\text { Azhagcsan et al. } \\
\text { [85] }\end{array}$ & Bubble-type embossing & $\mathrm{E}$ & $\begin{array}{l}\text { - Compared with flat PHE, bubble-type PHE } \\
\text { has a 1.2-1.5 times higher heat transfer } \\
\text { rate. }\end{array}$ \\
\hline $\begin{array}{l}\text { Villanueva and } \\
\text { Mello [86] }\end{array}$ & $\begin{array}{l}\text { Horseshoe-type } \\
\text { embossing }\end{array}$ & $\mathrm{N}$ & $\begin{array}{l}\text { - Three geometrical parameters of } \\
\text { horseshoe-type embossing were studied by } \\
\text { using CFD. } \\
\text { - Local heat transfer enhancement with } \\
\text { horseshoe shape is observed in front of the } \\
\text { fin. }\end{array}$ \\
\hline $\begin{array}{l}\text { Zhang et al. } \\
\text { [88] }\end{array}$ & $\begin{array}{l}\text { Circular spot-type } \\
\text { embossing }\end{array}$ & $E \& N$ & $\begin{array}{l}\text { - Novel PHE has better exergy performance } \\
\text { than the chevron corrugation PHE. } \\
\text { Entransy transfer efficiency of the novel } \\
\text { PHE is about 1.65-1.91 times more than } \\
\text { that of a flat PHE. }\end{array}$ \\
\hline Kim et al. [89] & Double-wave plate & $\mathrm{E}$ & $\begin{array}{l}\text { Heat transfer performance and } \Delta \mathrm{P} \text { of a } \\
\text { double-wave PHE increase by } 50 \% \text { and } \\
30 \% \text {, respectively, compared with a } \\
\text { chevron corrugation PHE. }\end{array}$ \\
\hline Doo et al. [90] & $\begin{array}{l}\text { In-phase, anti-phase and } \\
\text { full-wave rectified } \\
\text { secondary corrugation }\end{array}$ & $\mathrm{N}$ & $\begin{array}{l}\text { In-phase secondary corrugation has the } \\
\text { maximum increase of approximately } 7 \% \\
\text { and } 38 \% \text { in } \mathrm{Nu} \text { and } f \text { compared with } \\
\text { chevron corrugation. } \\
\text { Anti-phase secondary corrugation has the } \\
\text { best performance. }\end{array}$ \\
\hline Luan et al. [93] & $\begin{array}{l}\text { Transverse and } \\
\text { longitudinal corrugation }\end{array}$ & $\mathrm{N}$ & $\begin{array}{l}\text { - Nu and } f \text { of compound corrugation PHE } \\
\text { decrease by } 25 \% \text { and } 50 \% \text { compared with } \\
\text { the chevron corrugation PHEs. }\end{array}$ \\
\hline Cao et al. [94] & $\begin{array}{l}\text { Transverse and } \\
\text { longitudinal corrugation }\end{array}$ & & $\begin{array}{l}\text { - Using high-viscosity fluid as working fluid, } \\
\text { compound corrugation has about } 40 \% \\
\text { higher } j \text { and } 10 \% \text { lower } f \text { compared with } \\
\text { traditional chevron corrugation. }\end{array}$ \\
\hline $\begin{array}{l}\text { Nilpueng and } \\
\text { Wongwises [95] }\end{array}$ & $\begin{array}{l}\text { Roughened plate } \\
\text { surface (sand) }\end{array}$ & $\mathrm{E}$ & $\begin{array}{l}\text { The roughened surface with } \mathrm{R}=3.312 \mu \mathrm{m} \\
\text { has about } 18 \% \text { higher Nu and } 19 \% \text { higher } \\
\Delta \mathrm{P} \text { compared with the smooth surface. } \\
\text { The roughened surface with } \mathrm{R}=3.312 \mu \mathrm{m} \\
\text { has the highest PEC of } 1.2 \text { at } \mathrm{Re} \approx 1400 \text {. }\end{array}$ \\
\hline
\end{tabular}




\begin{tabular}{|c|c|c|c|}
\hline $\begin{array}{l}\text { Wajs and } \\
\text { Mikielewicz } \\
{[96]}\end{array}$ & $\begin{array}{l}\text { Roughened plate } \\
\text { surface (glass bead) }\end{array}$ & $\mathrm{E}$ & $\begin{array}{l}\text { - PHE with rough surface has the higher } \mathrm{h} \\
\text { only at low mass flux of hot water. }\end{array}$ \\
\hline $\begin{array}{l}\text { Wajs and } \\
\text { Mikielewicz } \\
{[97]}\end{array}$ & $\begin{array}{l}\text { Roughened plate } \\
\text { surface (metallic porous } \\
\text { microlayer) }\end{array}$ & $\mathrm{E}$ & $\begin{array}{l}\text { - Overall h of the modified PHE increases by } \\
2-10 \% \text {. } \\
\text { - } \quad f \text { increase by } 137 \% \text { at } \operatorname{Re}=93 \text {. } \\
\text { - The increase of } f \text { is smaller than } 9 \% \text { for } \\
\operatorname{Re}>430 .\end{array}$ \\
\hline $\begin{array}{l}\text { Nilpueng et al. } \\
{[98]}\end{array}$ & $\begin{array}{l}\text { Roughened plate } \\
\text { surface (sand) }\end{array}$ & $\mathrm{E}$ & $\begin{array}{l}\text { The roughened surface with } \mathrm{R}=2.75 \mu \mathrm{m} \\
\text { has about } 10 \% \text { and } 22 \% \text { higher } \mathrm{h} \\
\text { compared with the smooth surface for } \beta= \\
30^{\circ} \text { and } 60^{\circ} \text {, respectively. }\end{array}$ \\
\hline
\end{tabular}

\subsubsection{Two-phase enhancement}

The available studies using passive surface techniques in the PHEs for two-phase heat transfer are much less than those of single-phase flow.

Matsushima and Uchida [99] investigated experimentally the evaporation performance of a new PHE with pyramid-type embossing. The experimental results demonstrate that the new pyramid-type PHE has 1.5-2 times higher heat transfer coefficients than a commercial chevron corrugation PHE, while there is no significant difference in pressure drop found between these two PHEs.

Longo et al. [100] presented an experimental work applying a rough surface and a "crossgrooved" surface to refrigerant vaporization and condensation in a PHE with chevron corrugation. Figure 10 shows the scanning electron microscope (SEM) images of smooth, rough and "crossgrooved" surfaces, as well as a photo of the "cross-grooved" plate. The experimental results indicate that the "cross-grooved" surface is useful in both vaporization and condensation, giving an increase in the heat transfer coefficient on the refrigerant side by $30-40 \%$ during vaporization and by $60 \%$ during condensation compared with a smooth surface. The "cross-grooved" surface presents a penalty in pressure drop compared with a smooth surface, ranging from $10 \%$ to $20 \%$. Meanwhile, their results indicate that the rough surface could improve the heat transfer coefficient 
during vaporization by $30-40 \%$. However, it failed to enhance the heat transfer during condensation.

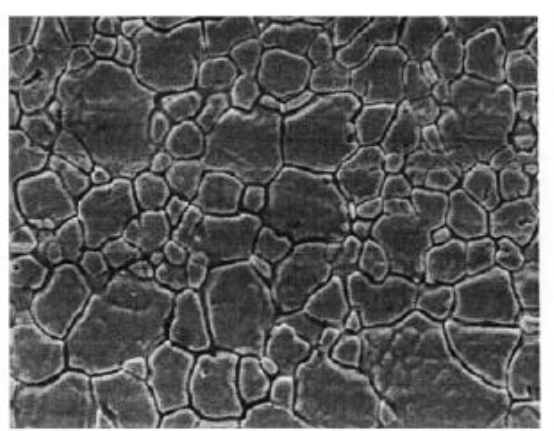

(a)

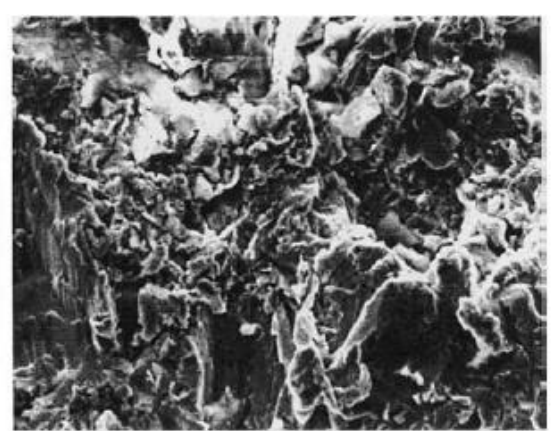

(b)

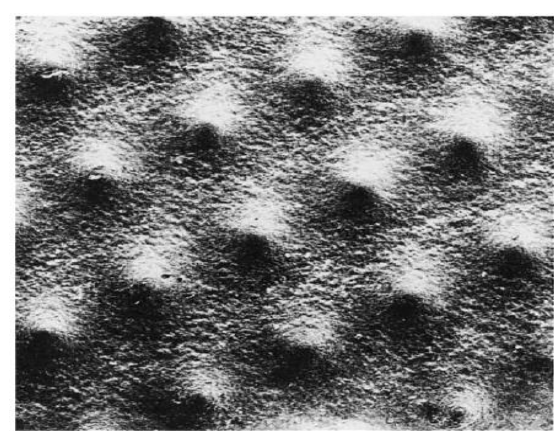

(c)

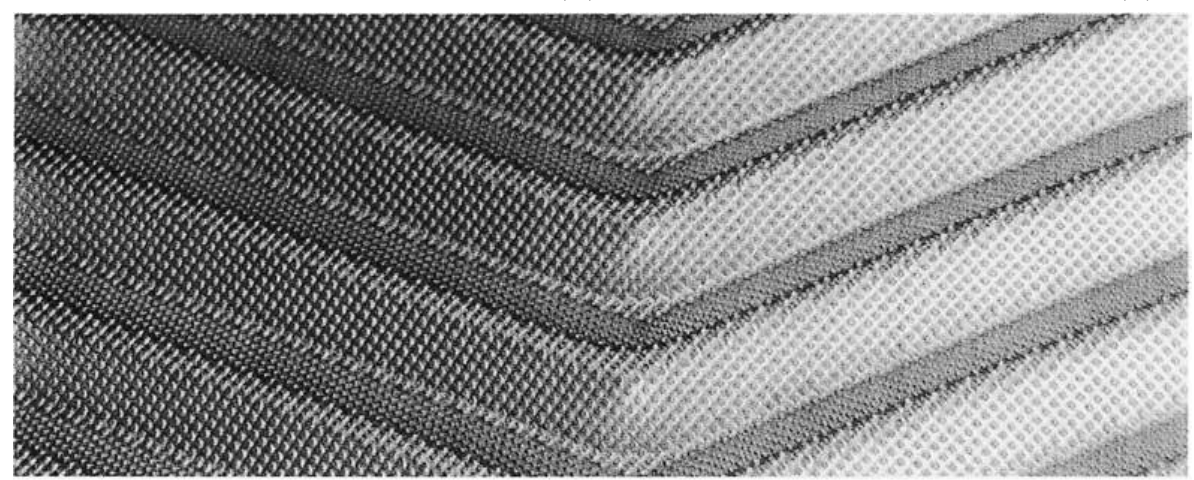

(d)

Figure 10 SEM images of (a) smooth surface, (b) rough surface and (c) "Cross-grooved" surface, and (d) Photo of the "cross-grooved" plate [100].

Furberg et al. [101] compared the performances of two chevron corrugation PHE evaporators, with and without a novel nano- and microporous copper structure. Their study also investigated the influence of the plate distance frame. A ten-fold increase in the heat transfer coefficient by the nano- and the microporous copper structure was found at the largest distance frame of $10 \mathrm{~mm}$. As a result, the overall heat transfer coefficient was improved by over $100 \%$. In addition, the heat transfer coefficient increased with increasing distance frame, perhaps due to the fact that the larger distance frame facilitates the rising of vapor bubbles. Although the study does not name a detailed flow characteristic, it claims that the porous structure does not noticeably affect the pressure drop in the refrigerant channel. 
Soontarapiromsook et al. [102] employed the roughed surfaces with $\mathrm{R}_{a}=1.816 \mu \mathrm{m}$ and 2.754 $\mu \mathrm{m}$ to improve condensation heat transfer in a gasketed PHE. The experimental results suggest that the heat transfer coefficient and frictional pressure gradient of the roughened plate surface is higher than that of a smooth plate surface by $31-44 \%$ and $14-29 \%$, respectively.

\subsection{Applications of nanofluids}

In 1995, Choi [103] first proposed the concept of nanofluid as a new type of fluid, consisting of a uniform dispersion of nanometer-sized solid particles. Subsequently, a number of works have studied the thermophysical properties of nanofluids, as well as their enhanced heat transfer performance. To the best of the authors' knowledge, although numerous studies have investigated the two-phase heat transfer characteristics of nanofluids in other devices (e.g. in an annular heat exchanger [104] or in a heat pipe heat exchanger [105]), the applications of nanofluids within PHEs are only developed in the single-phase flow, while their two-phase application in PHEs is not available in the open literature. Therefore, the literature review in this section focuses on the enhancement performance of nanofluids for the single-phase heat transfer in PHEs.

\subsubsection{Thermophysical properties of nanofluids}

A detailed analysis of the experimental measurements of thermophysical properties of nanofluids reveals high inconsistency in the data, which can be a consequence of the lack of stability or homogenization, or the low accuracy of the measuring instrumentation. Moreover, the developed correlations for the estimation of nanofluids' properties show good predictions only for some nanofluids, or under certain temperature ranges. Therefore, one could expect that the study of the heat transfer of nanofluids could be affected by the mentioned deviations in thermophysical properties. In this section, the nanofluid properties of interest for heat transfer processes (i.e. density $\rho$, isobaric heat capacity $\mathrm{c}_{\mathrm{p}}$, thermal conductivity $\mathrm{k}$, and dynamic viscosity $\mu$ ) are discussed and their variation depending on the nanoparticle concentration and type are summarized. The 
analysis presented here is based on published experimental data of aqueous nanofluids containing the nanoparticles of $\mathrm{Al}_{2} \mathrm{O}_{3}, \mathrm{ZnO}, \mathrm{CuO}, \mathrm{SiO}_{2}, \mathrm{CeO}_{2}, \mathrm{TiO}_{2}$, carbon nanotube (CNT), or $\mathrm{Ag}$, and mixtures of ethylene glycol and water with $\mathrm{Al}_{2} \mathrm{O}_{3}$ nanoparticles, which are prevalent in PHE related studies. Generally, the density and thermal conductivity of the fluid increase up to $20 \%$ for nanoparticle concentrations of less than $5 \%$, while the isobaric heat capacity decreases in a similar proportion, and the viscosity can even double its value for the same nanoparticle concentration. The accurate prediction of the thermophysical properties of nanofluids can be complex due to many influential factors, such as the nanoparticle shape [106] and equivalent diameter, and the nanofluid preparation [107] and stability [108]. In this regard, one finds a great scattering of the analyzed experimental data, especially for viscosity and thermal conductivity, and although there are a number of correlations developed for the prediction of the thermophysical properties of nanofluids, one could only use many of these for certain nanofluids, or under specific conditions.

In order to predict the density of a nanofluid, one commonly uses a linear correlation between the nanoparticle and the base fluid densities, considered with respect to the volume ratio of nanoparticles. By comparing this correlation with the analyzed experimental data, one observes an average absolute relative deviation (AARD) of less than $1.6 \%$. The prediction of the isobaric heat capacity is also often through using a linear correlation with the heat capacities of both the base fluid and the nanoparticle. This correlation predicts the analyzed experimental data within less than $4.5 \%$ of deviation. Regarding thermal conductivity, Hamilton et al. [109] developed a correlation that showed the lowest AARD with respect to the analyzed experimental data (i.e. less than $11 \%$ ), although these were as high as $20 \%$ for $\mathrm{TiO}_{2}$ nanofluids. Lastly, the analyzed experimental values for the dynamic viscosity showed large deviations, both among the results from different authors for the same nanofluid, and compared to estimated values from different correlations. Ho et al. [110] proposed the correlation that showed lower AARD, $18 \%$ (although 
especially high deviations were found for the case of the ethylene glycol - water based nanofluids). Figure 11 summarizes the AARD of the studied experimental data for each property and nanoparticle type. These uncertainties in the prediction of the thermophysical properties of nanofluids indicate that one should consider the effect of the fluid properties when analyzing the heat transfer of nanofluids, as they could have an impact on the experimental measurements and/or the development of correlations.

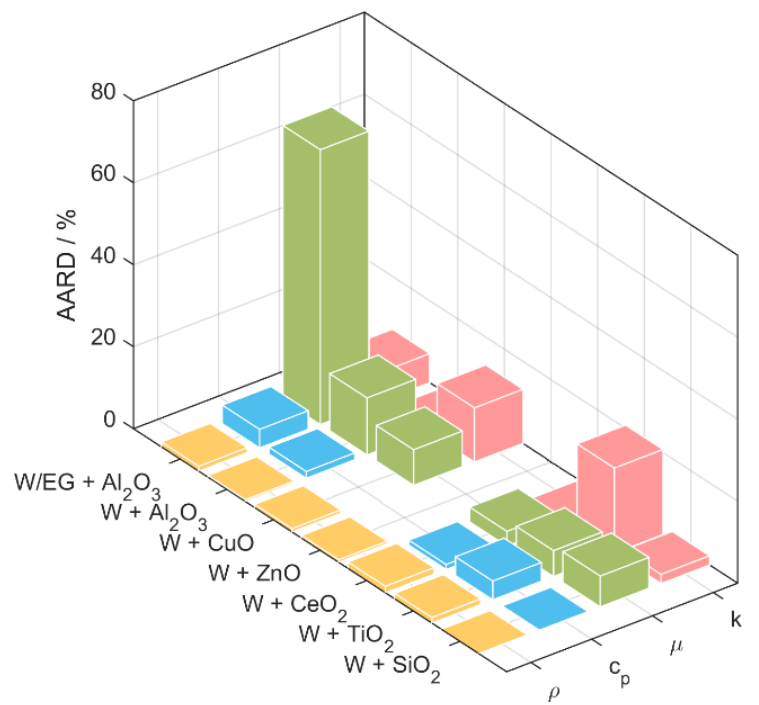

Figure 11 Absolute average relative deviations (AARD) of the analyzed experimental data of density, isobaric heat capacity, dynamic viscosity, and thermal conductivity with respect to the above-mentioned correlations, for each type of nanoparticle.

\subsubsection{Single-phase heat transfer}

The main parameters in the study of nanofluids include volume/weight concentration $\varphi / \omega$, particle type, particle diameter $d_{p}$ and particle shape. Particularly the concentration is of great interest, since research shows it is a key element in determining the flow and heat transfer performances. Table 4 summarizes the studies on PHEs with nanofluids as working fluids.

A common conclusion with respect to nanofluids is that the heat transfer coefficient increases with increasing particle concentration [111,112,121-123,113-120]. Zamzamian et al. [111] added 
$\mathrm{Al}_{2} \mathrm{O}_{3}$ and $\mathrm{CuO}$ nanoparticles to ethylene glycol (EG) at various weight concentrations of $0.1 \%$, $0.3 \%, 0.5 \%, 0.7 \%$ and $1 \%$, and investigated experimentally the heat transfer performance of nanofluids in both a double pipe and a PHE. The experimental data suggest that homogenously dispersed and stabilized nanoparticles enhanced the heat transfer, and the effects increase with the concentration. Moreover, the heat transfer enhancement in the PHE by using nanofluids compared with that of the base fluid is more significant than that in the double pipe heat exchanger. Tabari and Heris [117] prepared multi-walled carbon nanotubes (MWCNT) aqueous nanofluids with three weight concentrations $(\omega=0.25 \%, 0.35 \%$ and $0.55 \%)$ using MWCNT nanoparticles with diameters of 5-15 $\mathrm{nm}$ and $20 \mu \mathrm{m}$ in length. The experimental results indicate that the heat transfer coefficient increases with the weight concentration and Peclet number. Furthermore, heat transfer enhancement showed more effectiveness of the presence of nanoparticles in water at high flow rates.

However, results in the Refs. [124-133] contradict the above-mentioned results. Pandey and Nema [124] presented an experimental study of convective heat transfer in a chevron corrugation PHE using $\mathrm{Al}_{2} \mathrm{O}_{3}$-water nanofluids with different volume concentrations of $\varphi=2 \%, 3 \%$ and $4 \%$. The nanofluids showed higher thermal performance than the pure base fluid, and the heat transfer coefficients increased with the decrease of volume concentration for the same Peclet Number. Tiwari et al. [125] investigated experimentally the heat transfer performance of a PHE using different nanofluids $\left(\mathrm{CeO}_{2-}, \mathrm{Al}_{2} \mathrm{O}_{3^{-}}, \mathrm{TiO}_{2^{-}}\right.$and $\mathrm{SiO}_{2}$-water $)$ for various volume flow rates and a wide range of concentrations $(\varphi=0.5-3 \%)$. As shown in Figure 12, the maximum enhancement of the overall heat transfer coefficient of $\mathrm{CeO}_{2^{-}}, \mathrm{Al}_{2} \mathrm{O}_{3^{-}}, \mathrm{TiO}_{2^{-}}$and $\mathrm{SiO}_{2}$-water nanofluids occurred at $\varphi=0.75 \%, 1.0 \%, 0.75 \%$ and $1.25 \%$, respectively. The results indicate that the $\mathrm{CeO}_{2}-\mathrm{water}$ nanofluid has the best heat transfer performance among all the nanofluids. Sarafraz and Hormozi [133] performed an experimental investigation of the forced convection of MWCNT-water 
nanofluids with $\varphi=0.5 \%, 1.0 \%$ and $1.5 \%$ in a chevron type PHE. The results demonstrate that the best thermal performance amongst these concentrations occurs when $\varphi=1 \%$, which indicates an optimum concentration.
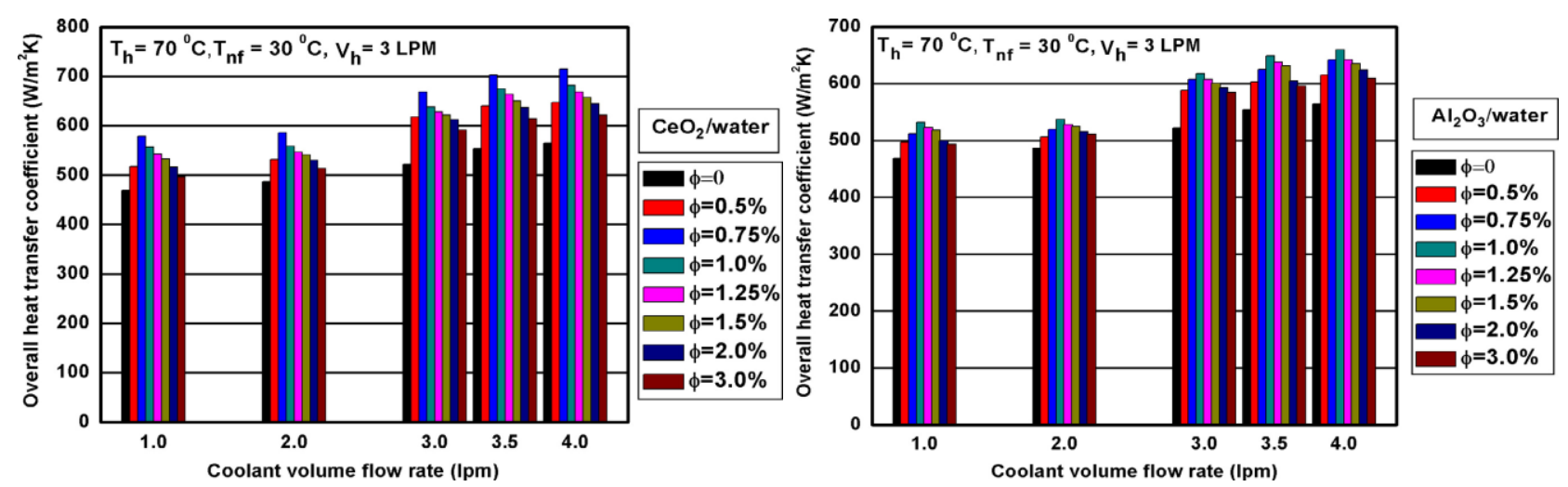

(a)

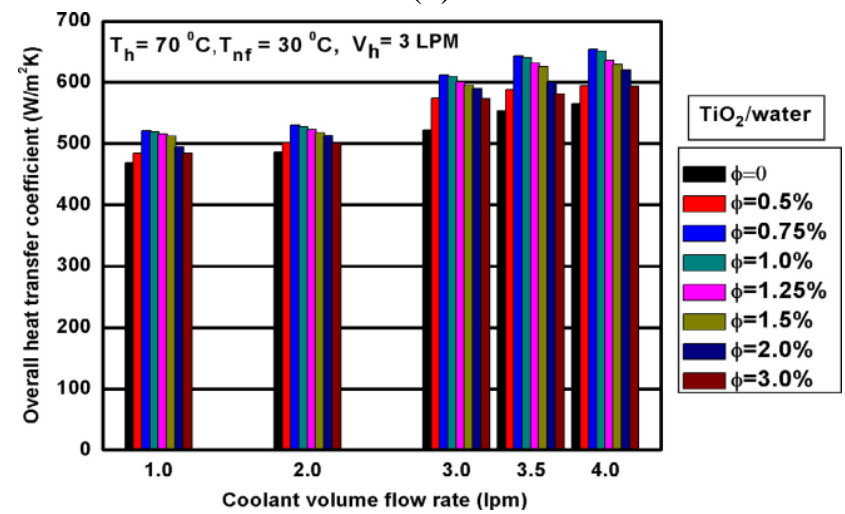

(c)

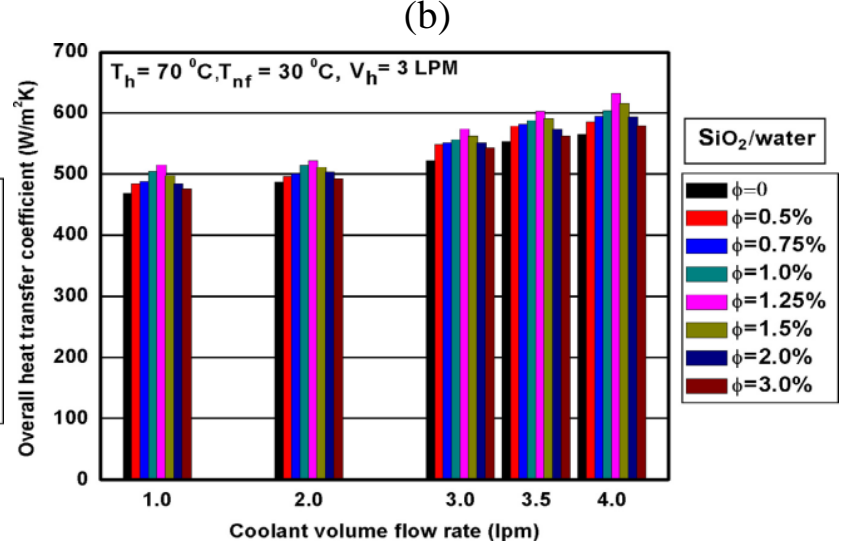

(d)

Figure 12 Variation of overall heat transfer coefficient tested at different coolant flow rates with various volume concentrations for (a) $\mathrm{CeO}_{2}$, (b) $\mathrm{Al}_{2} \mathrm{O}_{3}$, (c) $\mathrm{TiO}_{2}$ and (d) $\mathrm{SiO}_{2}$ [125].

In addition to the concentration, the comparison of thermal and hydraulic performance among different types of nanofluids is another topic of interest $[115,116,122,125,127,129,134]$ aiming to define the optimum particle type. Abed et al. [116] investigated numerically the effects of four different types of nanoparticles $\left(\mathrm{Al}_{2} \mathrm{O}_{3}, \mathrm{CuO}, \mathrm{SiO}_{2}\right.$ and $\left.\mathrm{ZnO}\right)$ on a fully developed turbulent flow in a PHE. The numerical results indicate that $\mathrm{SiO}_{2}$ has the highest Nusselt number and pressure drop followed by $\mathrm{Al}_{2} \mathrm{O}_{3}, \mathrm{ZnO}$, and $\mathrm{CuO}$, while the $\mathrm{CuO}$-water nanofluid is more prone to enhance the thermal-hydraulic performance. Sun et al. [122] used nanoparticles $\left(\mathrm{Cu}, \mathrm{Fe}_{2} \mathrm{O}_{3}\right.$ and $\left.\mathrm{Al}_{2} \mathrm{O}_{3}\right)$ 
with an average particle size of $50 \mathrm{~nm}$, and analyzed the flow and convective heat transfer characteristics of the nanofluids in a PHE. The $\mathrm{Cu}$-water nanofluid has the best heat transfer performance. The particle type, however, did not show a distinct effect on the friction factor in the PHE. Kumar et al. [129] presented an experimental investigation of the effect of different spacings in PHEs by using various nanofluids, i.e., $\mathrm{TiO}_{2}, \mathrm{Al}_{2} \mathrm{O}_{3}, \mathrm{ZnO}, \mathrm{CeO}_{2}$, hybrid $\left(\mathrm{Cu}+\mathrm{Al}_{2} \mathrm{O}_{3}\right)$, graphene nanoplate (GNP) and MWCNT. The experimental results suggest that the MWCNT-water nanofluid attains the best heat transfer performance and lowest pressure drop, yielding the maximum exergetic efficiency among the tested nanofluids.

Table 4 Summary of studies using nanofluids as working fluids in PHEs.

\begin{tabular}{|c|c|c|c|c|c|c|}
\hline Authors & Method & $\begin{array}{l}\text { Base } \\
\text { fluid }\end{array}$ & Particle & $\omega / \varphi$ & $\begin{array}{l}\mathrm{d}_{p} \\
(\mathrm{~nm})\end{array}$ & Key findings \\
\hline $\begin{array}{l}\text { Zamzamian } \\
\text { et al. [111] }\end{array}$ & $E$ & $\begin{array}{l}\text { ethylene } \\
\text { glycol }\end{array}$ & $\begin{array}{l}\mathrm{Al}_{2} \mathrm{O}_{3}, \\
\mathrm{CuO}\end{array}$ & $\begin{array}{l}\omega= \\
0.1- \\
1 \%\end{array}$ & 20 & $\begin{array}{ll}\text { - } & \mathrm{Nu} \text { increases with } \varphi . \\
\text { - } & \text { For } \mathrm{Al}_{2} \mathrm{O}_{3}-\mathrm{EG} \text { and } \mathrm{CuO}- \\
\text { EG, the maximum } \\
\text { increases in } \mathrm{Nu} \text { are } 38 \% \\
\text { and } 49 \% \text { at } \omega=1 \% \text {. }\end{array}$ \\
\hline $\begin{array}{l}\text { Kanjirakat } \\
\text { and Sadr } \\
{[112]}\end{array}$ & $\mathrm{E}$ & water & $\mathrm{SiO}_{2}$ & $\begin{array}{l}\omega=1- \\
5 \%\end{array}$ & 20 & $\begin{array}{l}\text { - } \quad \mathrm{h} \text { and } \Delta \mathrm{P} \text { increase with } \varphi \text {. } \\
\text { Overall } \mathrm{h} \text { is enhanced by } \\
4 \% \text { at } \omega=5 \% \text {, while } \Delta \mathrm{P} \\
\text { increased by } 18 \% \text {. }\end{array}$ \\
\hline $\begin{array}{l}\text { Kabeel et al. } \\
\text { [113] }\end{array}$ & E & water & $\mathrm{Al}_{2} \mathrm{O}_{3}$ & $\begin{array}{l}\varphi=1- \\
4 \%\end{array}$ & 47 & $\begin{array}{l}\text { - } \mathrm{h} \text { and } \Delta \mathrm{P} \text { increase with } \varphi \text {. } \\
\text { For } \varphi=4 \% \text {, the } \\
\text { maximum increases in } \mathrm{h} \\
\text { and } \Delta \mathrm{P} \text { are } 13 \% \text { and } \\
45 \% \text {. }\end{array}$ \\
\hline $\begin{array}{l}\text { Khairul et al. } \\
\text { [114] }\end{array}$ & $\mathrm{E}$ & water & $\mathrm{CuO}$ & $\begin{array}{l}\varphi= \\
0.5- \\
1.5 \%\end{array}$ & - & $\begin{array}{l}\text { - } \quad \mathrm{h} \text { and } \Delta \mathrm{P} \text { increase with } \varphi \text {. } \\
\text { - } \mathrm{As} \varphi=1.5 \%, \mathrm{~h} \text { increases } \\
\text { by } 27.2 \% \text {. } \\
\text { - } \quad \text { Exergy loss is reduced by } \\
24 \% \text { as } \varphi=1.5 \% \text {. }\end{array}$ \\
\hline $\begin{array}{l}\text { Elias et al. } \\
{[115]}\end{array}$ & $\mathrm{N}$ & water & $\begin{array}{l}\mathrm{Al}_{2} \mathrm{O}_{3} \\
\mathrm{SiO}_{2}\end{array}$ & $\begin{array}{l}\varphi=0 \\
1 \%\end{array}$ & - & $\begin{array}{l}\text { - } \mathrm{h} \text { increases with } \varphi . \\
\mathrm{Al}_{2} \mathrm{O}_{3} \text {-water has the } \\
\text { better heat transfer } \\
\text { performance than } \mathrm{SiO}_{2^{-}} \\
\text {water. } \\
\text { - Larger chevron angle } \\
\text { corresponds to a higher h. }\end{array}$ \\
\hline $\begin{array}{l}\text { Abed et al. } \\
{[116]}\end{array}$ & $\mathrm{N}$ & water & $\begin{array}{l}\mathrm{Al}_{2} \mathrm{O}_{3} \\
\mathrm{CuO} \\
\mathrm{SiO}_{2} \text { and } \\
\mathrm{ZnO}\end{array}$ & $\begin{array}{l}\varphi=0 \\
4 \%\end{array}$ & $\begin{array}{l}20- \\
80\end{array}$ & $\begin{array}{l}\text { - } \mathrm{h} \text { and } \Delta \mathrm{P} \text { increase with } \varphi \text {. } \\
\text { As } \varphi=4 \%, \mathrm{SiO}_{2} \text {-water } \\
\text { has the maximum } \\
\text { increase in } \mathrm{Nu} \text { by up to }\end{array}$ \\
\hline
\end{tabular}




\begin{tabular}{|c|c|c|c|c|c|c|}
\hline $\begin{array}{l}\text { Tabari and } \\
\text { Heris [117] }\end{array}$ & $\mathrm{E}$ & water & $\begin{array}{l}\text { MWCN } \\
\mathrm{T}\end{array}$ & $\begin{array}{l}\omega= \\
0.25- \\
0.55 \%\end{array}$ & 5-15 & 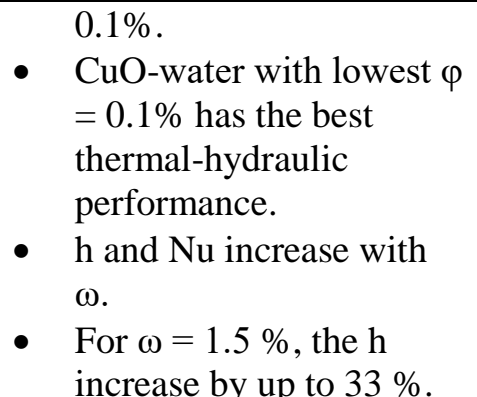 \\
\hline $\begin{array}{l}\text { Goodarzi et } \\
\text { al. [118] }\end{array}$ & $\mathrm{N}$ & water & $\begin{array}{l}\text { MWCN } \\
\text { T-Ag }\end{array}$ & $\begin{array}{l}\varphi= \\
0.5- \\
1 \%\end{array}$ & $\begin{array}{l}10- \\
20\end{array}$ & $\begin{array}{l}\text { - } \mathrm{h} \text { and } \Delta \mathrm{P} \text { increase with } \varphi \text {. } \\
\text { - For } \varphi=1 \% \text {, the } \mathrm{h} \\
\text { increase by up to } 41 \% \text {. }\end{array}$ \\
\hline $\begin{array}{l}\text { Unverdi and } \\
\text { Islamoglu } \\
{[119]}\end{array}$ & $\mathrm{E}$ & water & $\mathrm{Al}_{2} \mathrm{O}_{3}$ & $\begin{array}{l}\varphi= \\
0.25- \\
1 \%\end{array}$ & 40 & $\begin{array}{l}\text { - } \quad \text { and } f \text { increase with } \varphi \text {. } \\
\text { For } \varphi=1 \% \text {, the average } \\
\text { increases in Nu and } f \text { are } \\
42.4 \% \text { and } 20 \% \text {. }\end{array}$ \\
\hline $\begin{array}{l}\text { Prashant et } \\
\text { al. [120] }\end{array}$ & $\mathrm{E}$ & water & $\mathrm{Al}_{2} \mathrm{O}_{3}$ & $\begin{array}{l}\varphi= \\
0.1- \\
0.2 \%\end{array}$ & 47 & $\begin{array}{l}\text { - } \mathrm{h} \text { increases with } \varphi . \\
\text { - } \quad \text { For } \varphi=0.2 \%, \mathrm{~h} \\
\text { increases by } 30 \% .\end{array}$ \\
\hline $\begin{array}{l}\text { Barzegarian } \\
\text { et al. [121]/E }\end{array}$ & $\mathrm{E}$ & water & $\mathrm{TiO}_{2}$ & $\begin{array}{l}\omega= \\
0.3- \\
1.5 \%\end{array}$ & 20 & $\begin{array}{l}-\mathrm{h} \text { and } \Delta \mathrm{P} \text { increase with } \omega \text {. } \\
\text { - For } \omega=1.5 \%, \mathrm{~h} \text { and } \Delta \mathrm{P} \\
\text { increase by up to } 23.7 \% \\
\text { and } 20 \% \text {. }\end{array}$ \\
\hline $\begin{array}{l}\text { Sun et al. } \\
\text { [122] }\end{array}$ & $\mathrm{E}$ & water & $\begin{array}{l}\mathrm{Cu} \\
\mathrm{Fe}_{2} \mathrm{O}_{3} \\
\text { and } \\
\mathrm{Al}_{2} \mathrm{O}_{3}\end{array}$ & $\begin{array}{l}\omega= \\
0.1- \\
0.5 \%\end{array}$ & 50 & $\begin{array}{l}\text { - } \quad \text { h and } f \text { increase with } \omega . \\
\text { For } \omega=0.5 \%, \text { h of the } \\
\text { Cu-water nanofluid } \\
\text { increases by up to } 35 \% \text {. }\end{array}$ \\
\hline $\begin{array}{l}\text { Taghizadeh- } \\
\text { Tabari et al. } \\
\text { [123] }\end{array}$ & $\mathrm{E}$ & water & $\mathrm{TiO}_{2}$ & $\begin{array}{l}\omega \\
=0.25- \\
0.8 \%\end{array}$ & $\begin{array}{l}10- \\
15\end{array}$ & $\begin{array}{l}\text { - } \mathrm{Nu} \text { and } \Delta \mathrm{P} \text { increase with } \\
\omega . \\
\text { - For } \omega=0.8 \%, \mathrm{Nu} \text { and } \Delta \mathrm{P} \\
\text { increase by up to } 17 \% \\
\text { and } 8 \% \text {. }\end{array}$ \\
\hline $\begin{array}{l}\text { Pandey and } \\
\text { Nema [124] }\end{array}$ & $\mathrm{E}$ & water & $\mathrm{Al}_{2} \mathrm{O}_{3}$ & $\begin{array}{l}\varphi=2- \\
4 \%\end{array}$ & $\begin{array}{l}40- \\
50\end{array}$ & $\begin{array}{l}\text { All the nanofluids have } \\
\text { higher } \mathrm{h} \text { than water. } \mathrm{h} \\
\text { decreases with } \varphi \text {. } \\
\text { As } \varphi=2 \% \text {, the } \mathrm{h} \\
\text { increases by up to } 11 \% \text {. }\end{array}$ \\
\hline $\begin{array}{l}\text { Tiwari et al. } \\
\text { [125-127] }\end{array}$ & $\mathrm{E}$ & water & $\begin{array}{l}\mathrm{CeO}_{2} \\
\mathrm{Al}_{2} \mathrm{O}_{3} \\
\mathrm{TiO}_{2} \text { and } \\
\mathrm{SiO}_{2}\end{array}$ & $\begin{array}{l}\varphi= \\
0.5- \\
3 \%\end{array}$ & 30 & $\begin{array}{l}\text { Various nanofluids have } \\
\text { different optimum } \varphi \text {. } \\
\text { As } \varphi=0.75 \% \text {, h of } \\
\mathrm{CeO}_{2} \text {-water nanofluid } \\
\text { increases by up to } \\
35.9 \% \text {. }\end{array}$ \\
\hline $\begin{array}{l}\text { Kumar et al. } \\
\text { [129] }\end{array}$ & $\mathrm{E}$ & water & $\begin{array}{l}\mathrm{CeO}_{2}, \\
\mathrm{Al}_{2} \mathrm{O}_{3}, \\
\mathrm{TiO}_{2}, \\
\mathrm{SiO}_{2}, \\
\mathrm{Cu}+\mathrm{Al}_{2} \\
\mathrm{O}_{3}, \\
\mathrm{GNP}, \\
\text { MWCN }\end{array}$ & $\begin{array}{l}\varphi= \\
0.5- \\
2 \%\end{array}$ & - & $\begin{array}{l}\text { - As } \varphi=0.75 \% \text { and } S=5 \\
\text { mm, h of MWCNT-water } \\
\text { nanofluid increases by up } \\
\text { to } 53.05 \% .\end{array}$ \\
\hline
\end{tabular}




\begin{tabular}{|c|c|c|c|c|c|c|}
\hline & & & $\mathrm{T}$ & & & \\
\hline $\begin{array}{l}\text { Kumar et al. } \\
{[130]}\end{array}$ & $\mathrm{E}$ & water & $\mathrm{ZnO}$ & $\begin{array}{l}\varphi= \\
0.25- \\
2 \%\end{array}$ & - & $\begin{array}{l}\text { - As } \varphi=0.75 \% \text { and } \beta= \\
60^{\circ} / 60^{\circ}, \mathrm{h} \text { increases by } \\
\text { up to } 32.2 \% \text {. }\end{array}$ \\
\hline $\begin{array}{l}\text { Jokar and } \\
\text { O'Halloran } \\
{[131]}\end{array}$ & $\mathrm{N}$ & water & $\mathrm{Al}_{2} \mathrm{O}_{3}$ & $\begin{array}{l}\varphi=1- \\
4 \%\end{array}$ & 36 & $\begin{array}{l}\text { - Heat transfer rate } \\
\text { decreases slightly with } \\
\text { increasing } \varphi \text {. }\end{array}$ \\
\hline $\begin{array}{l}\text { Gherasim et } \\
\text { al. [132] }\end{array}$ & $\mathrm{N}$ & water & $\begin{array}{l}\mathrm{CuO} \text { and } \\
\mathrm{Al}_{2} \mathrm{O}_{3}\end{array}$ & $\begin{array}{l}\varphi=1- \\
4.5 \%\end{array}$ & - & $\begin{array}{l}\text { All the nanofluids have } \\
\text { higher h than water. } \mathrm{h} \\
\text { decreases with } \varphi \text {. } \\
\text { - CuO-water nanofluid has } \\
\text { the better heat transfer } \\
\text { performance. }\end{array}$ \\
\hline $\begin{array}{l}\text { Sarafraz and } \\
\text { Hormozi } \\
{[133] / \mathrm{E}}\end{array}$ & $\mathrm{E}$ & water & $\begin{array}{l}\text { MWCN } \\
\mathrm{T}\end{array}$ & $\begin{array}{l}\varphi= \\
0.5- \\
1.5 \%\end{array}$ & - & $\begin{array}{l}\text { - For optimum } \varphi \text { of } 1 \% \text {, } \\
\text { Nu increases by up to } \\
14 \% \text {. }\end{array}$ \\
\hline $\begin{array}{l}\text { Stogiannis et } \\
\text { al. [135] }\end{array}$ & $E \& N$ & water & $\mathrm{SiO}_{2}$ & $\begin{array}{l}\varphi=1- \\
2 \%\end{array}$ & - & $\begin{array}{l}\text { - Increasing } \varphi \text { from } 1 \% \text { to } \\
2 \% \text { induces insignificant } \\
\text { increase in } \mathrm{h} \text { and a } 50 \% \\
\text { increase in } \Delta \mathrm{P} \text {. }\end{array}$ \\
\hline $\begin{array}{l}\text { Maré et al. } \\
{[136]}\end{array}$ & $\mathrm{E}$ & water & $\begin{array}{l}\mathrm{Al}_{2} \mathrm{O}_{3} \\
\text { and } \\
\text { CNT }\end{array}$ & $\begin{array}{l}\varphi=1 \% \\
\text { and } \\
0.55 \%\end{array}$ & $\begin{array}{l}37, \\
9-10\end{array}$ & $\begin{array}{l}\text { - } \mathrm{h} \text { increases by up to } 42 \% \\
\text { and } 50 \% \text { for } \mathrm{Al}_{2} \mathrm{O}_{3} \text {-water } \\
\text { and CNT-water. }\end{array}$ \\
\hline $\begin{array}{l}\text { Fard et al. } \\
{[137]}\end{array}$ & $\mathrm{E} \& N$ & water & $\mathrm{ZnO}$ & $\begin{array}{l}\varphi= \\
0.5 \%\end{array}$ & - & - $\mathrm{h}$ increases by $20 \%$. \\
\hline $\begin{array}{l}\text { Ray et al. } \\
\text { [138] }\end{array}$ & $E \& N$ & $\begin{array}{l}\text { EG/wat } \\
\text { er }\end{array}$ & $\mathrm{Al}_{2} \mathrm{O}_{3}$ & $\begin{array}{l}\varphi= \\
0.5 \%\end{array}$ & 45 & $\begin{array}{l}\text { - Convective and overall } \mathrm{h} \\
\text { increase by up to } 11 \% \\
\text { and } 4.85 \% \text {. }\end{array}$ \\
\hline $\begin{array}{l}\text { Huang et al. } \\
\text { [139] }\end{array}$ & $\mathrm{E}$ & water & $\begin{array}{l}\mathrm{Al}_{2} \mathrm{O}_{3}+ \\
\mathrm{MWCN} \\
\mathrm{T}\end{array}$ & $\begin{array}{l}\varphi= \\
1.48 \%\end{array}$ & $\begin{array}{l}40 \\
\text { and } \\
9.5\end{array}$ & $\begin{array}{l}\text { - Heat transfer is slightly } \\
\text { enhanced by using hybrid } \\
\text { nanofluid mixture } \\
\text { compared with } \mathrm{Al}_{2} \mathrm{O}_{3}- \\
\text { water. }\end{array}$ \\
\hline $\begin{array}{l}\text { Behrangzade } \\
\text { and Heyhat } \\
{[140]}\end{array}$ & $\mathrm{E}$ & water & $\mathrm{Ag}$ & $\begin{array}{l}\omega= \\
0.01 \%\end{array}$ & 5 & $\begin{array}{l}\text { - Overall } \mathrm{h} \text { increases by up } \\
\text { to } 17 \% \text {. } \\
\text { - No significant growth in } \\
\Delta \mathrm{P} \text {. }\end{array}$ \\
\hline $\begin{array}{l}\text { Ham et al. } \\
{[134]}\end{array}$ & $\mathrm{E}$ & $\begin{array}{l}\mathrm{LiBr} \\
\text { solution }\end{array}$ & $\begin{array}{l}\mathrm{Fe}_{2} \mathrm{O}_{3}, \\
\mathrm{CuO}, \\
\mathrm{Al}_{2} \mathrm{O}_{3}, \\
\mathrm{TiO}_{2}, \\
\mathrm{ZnO}, \\
\mathrm{SiO}_{2} \text { and } \\
\mathrm{CNT}\end{array}$ & $\begin{array}{l}\varphi=0- \\
0.1 \%\end{array}$ & - & $\begin{array}{l}\text { - } \mathrm{Fe}_{2} \mathrm{O}_{3} \text { and } \mathrm{CuO} \text { have the } \\
\text { highest heat transfer } \\
\text { performance. } \\
\mathrm{Al}_{2} \mathrm{O}_{3} \text { and } \mathrm{TiO}_{2} \text { have the } \\
\text { best performance based } \\
\text { on heat transfer } \\
\text { improvement and } \\
\text { limitation concentration } \\
\text { of the dispersion stability } \\
\text { of the nanofluid. }\end{array}$ \\
\hline $\begin{array}{l}\text { Pantzali et al. } \\
\text { [141] }\end{array}$ & $\mathrm{E}$ & water & $\begin{array}{l}\mathrm{Al}_{2} \mathrm{O}_{3} \\
\mathrm{CuO} \\
\mathrm{CNT} \\
\text { and } \mathrm{TiO}_{2}\end{array}$ & $\begin{array}{l}\varphi= \\
0.5- \\
8 \%\end{array}$ & $8-50$ & $\begin{array}{l}\text { - Use of nanofluids seems } \\
\text { advantageous only under } \\
\text { the laminar condition. }\end{array}$ \\
\hline
\end{tabular}




\begin{tabular}{|c|c|c|c|c|c|c|}
\hline $\begin{array}{l}\text { Taws et al. } \\
{[142]}\end{array}$ & $E$ & water & $\mathrm{CuO}$ & $\begin{array}{l}\varphi=2- \\
4.65 \%\end{array}$ & 29 & $\begin{array}{ll} & \text { For } \varphi=4.65 \%, \mathrm{~h} \\
\text { decreases. } \\
\text { - For } \varphi=2 \%, \text { no heat } \\
\text { transfer enhancement is } \\
\text { found. }\end{array}$ \\
\hline $\begin{array}{l}\text { Huang et al. } \\
{[143]}\end{array}$ & E & water & $\begin{array}{l}\mathrm{Al}_{2} \mathrm{O}_{3} \\
\mathrm{MWCN} \\
\mathrm{T}\end{array}$ & $\begin{array}{l}\varphi= \\
0.56- \\
2.84 \% \\
; \\
0.0111 \\
- \\
0.0555 \\
\%\end{array}$ & $\begin{array}{l}40 \\
\text { and } \\
9.5\end{array}$ & $\begin{array}{l}\text { - At the constant flow } \\
\text { velocity, heat transfer is } \\
\text { deteriorated by using } \\
\text { nanofluids. }\end{array}$ \\
\hline $\begin{array}{l}\text { Cieśliński et } \\
\text { al. [144] }\end{array}$ & E & water & $\mathrm{Al}_{2} \mathrm{O}_{3}$ & $\begin{array}{l}\omega= \\
0.1- \\
1 \%\end{array}$ & 47 & $\begin{array}{l}\text { - Addition of nanoparticles } \\
\text { resulted in deterioration } \\
\text { of } h \text {. }\end{array}$ \\
\hline $\begin{array}{l}\text { Bhattad et al. } \\
\text { [145] }\end{array}$ & $E \& N$ & water & $\begin{array}{l}\mathrm{Al}_{2} \mathrm{O}_{3}+ \\
\mathrm{MWCN} \\
\mathrm{T}\end{array}$ & $\begin{array}{l}\varphi= \\
0.01- \\
0.03 \%\end{array}$ & - & $\begin{array}{l}\text { - } \mathrm{h} \text { increases by up to } 39 \% \\
\text { at the same cost of } \\
\text { pumping power. }\end{array}$ \\
\hline $\begin{array}{l}\text { Pourhoseini } \\
\text { et al. [146] }\end{array}$ & E & water & Silver & $\begin{array}{l}2.5-10 \\
\mathrm{mg} / \mathrm{L}\end{array}$ & - & $\begin{array}{l}\text { - Overall } \mathrm{h} \text { increases by up } \\
\text { to } 54 \% \text {. }\end{array}$ \\
\hline $\begin{array}{l}\text { Wang et al. } \\
{[147]}\end{array}$ & E & $\begin{array}{l}\text { ethylene } \\
\text { glycol- } \\
\text { water }\end{array}$ & $\begin{array}{l}\text { Graphen } \\
\text { e } \\
\text { nanoplat } \\
\text { elets }\end{array}$ & $\begin{array}{l}\omega= \\
0.01- \\
1 \%\end{array}$ & $2 \mathrm{~nm}$ & $\begin{array}{l}\text { - } \mathrm{h} \text { increases with } \mathrm{Re} \text { and } \\
\omega . \\
\text { - } \mathrm{h} \text { increases by up to } \\
30 \% \text {. }\end{array}$ \\
\hline $\begin{array}{l}\text { Elias et al. } \\
{[148]}\end{array}$ & $\mathrm{E}$ & water & $\mathrm{Al}_{2} \mathrm{O}_{3}$ & $\begin{array}{l}\varphi=0 \\
0.5 \%\end{array}$ & - & $\begin{array}{l}\text { - } \quad \mathrm{h} \text { and } f \text { increase with } \varphi \text {. } \\
\text { - } \quad \text { Overall h increases by } \\
7.8 \% \text { as } \varphi=0.5 \%\end{array}$ \\
\hline
\end{tabular}

\subsection{Other enhancement techniques}

In addition to the passive surface techniques and nanofluid techniques discussed above, there exist a few novel enhancement techniques for single-phase flow in PHEs.

Tohidi et al. [149] rotated the chevron corrugation plate with a deviation angle from the vertical position, inducing the contact points inside a PHE not to be in the same line along the vertical direction. In this configuration of the plates, there was strengthening of the chaotic mixing of the flow, aiming to improve the heat transfer performance of the laminar convection of a food fluid with high viscosity (such as milk and milky desserts, fruit and vegetable juices, meat sauces, etc.). The numerical results show a positive Lyapunov exponent (the Lyapunov exponent is related to the specific stretching rate and mixing efficiency, evaluated as a long-term average for a system 
with an infinite space), indicating the existence of chaotic advection in the plates with deviation angles of $5^{\circ}, 10^{\circ}$ and $15^{\circ}$. The Nusselt numbers of deviated plates were almost two times higher than those of the original chevron corrugation plates, while there was only a marginal increase in pressure loss observed.

Abadi et al. [150,151] developed a metal-foam-filled channel of a PHE and used it as a test section to investigate experimentally both single-phase and two-phase flow characteristics of R245fa. Different metal-foam configurations with different pore densities of 20, 30, and 60 pores per inch (PPI) were employed in the experiments. Figure 13 shows one empty channel and one channel filled with a 20-PPI metal foam. The results indicate that, for single-phase flow, the 20PPI, 30-PPI and 60 PPI metal foam increase the heat transfer coefficient by up to 3.5, 4 and 5.1 times, respectively, and increase the pressure drop by up to 3.2, 3.8 and 5.7 times, respectively, compared with the empty channel [150]. As for the flow evaporation [151], the heat transfer was enhanced in all cases by the fitted metal foams, but the heat transfer enhancement effect of metal foam was found to be inversely related to the pore density.

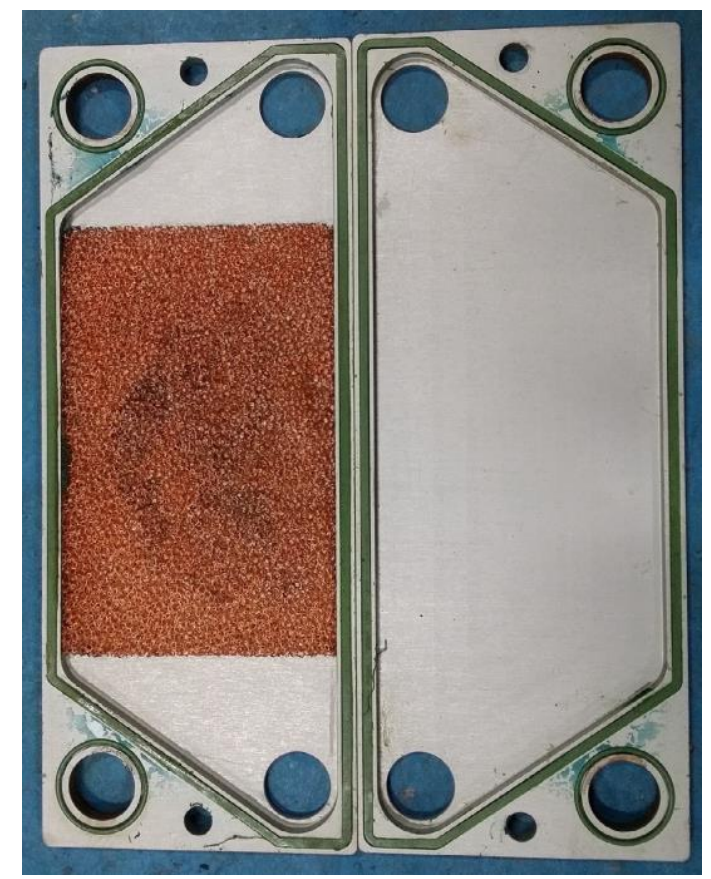


Figure 13 PHE with metal-foam-filled channels [150].

Jung et al. [152] studied the effects of pulsating flow on the evaporation heat transfer of R134a in a chevron-type PHE. The pulsating frequency of the refrigerant R134 varied in the range of 5-25 Hz. The experimental results indicate that the heat transfer enhancement by pulsating flow increases with the decrease of mass flux, and a maximum of $6.3 \%$ increase in the heat transfer coefficient occurs at $10 \mathrm{~Hz}$.

\section{Discussion}

This section discusses in detail the mechanisms governing the effects of geometrical parameters of chevron corrugation on thermal-hydraulic performance, as well as the augmented heat transfer performance by using enhancement techniques, based on the results and findings from a large body of relevant research papers. Moreover, the chevron corrugation PHEs with various geometrical parameters as well as the PHEs using different enhancement techniques are compared in terms of the performance evaluation criterion.

\subsection{Mechanism analysis}

This section discusses the following items: i) the influence mechanisms of the geometrical parameters of chevron corrugation PHEs on single-phase heat transfer, ii) the influence mechanisms of the geometrical parameters of chevron corrugation PHEs on two-phase heat transfer, iii) the enhancement mechanisms by using passive surface techniques, and iv) the enhancement mechanisms by using nanofluids.

\subsubsection{Effects of geometrical parameters on the single-phase heat transfer}

From the literature review in Section 2.1, it can be found that the chevron angle $\beta$ is the most influential parameter, mainly because of its effects on the basic flow structure. Specifically, two flow patterns coexist in the chevron-corrugated channels of PHEs. They are named differently by 
different research groups, for instance, criss-crossing stream and zig-zag flow in Ref. [19], furrow and wavy longitudinal flows in Refs. [24,25], flows in the furrow and streamwise directions in Ref. [48] and cross-flow type and helical flow type in Ref. [2]. In this paper, the furrow flow and the zig-zag flow are used to name the two flow patterns. By CFD simulation, Sarraf et al. [2] calculated the 3D flow streamlines of these two flow patterns inside a channel between two chevron corrugation plates as shown in Figure 14 (the furrow flow and the zig-zag flow were obtained at $\operatorname{Re}=21$ and 2100 , respectively).

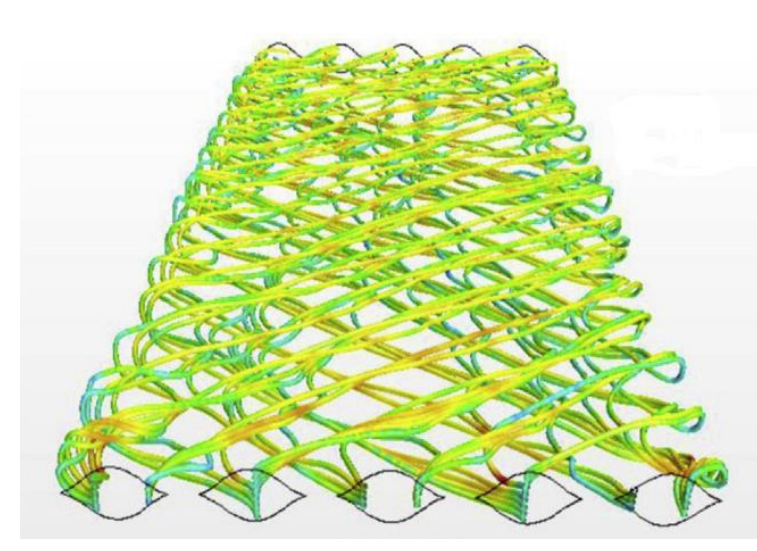

(a)

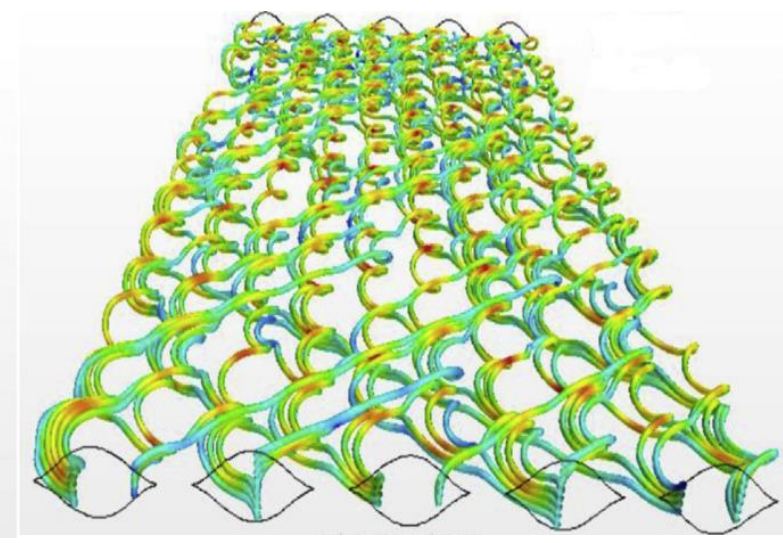

(b)

Figure 14 Three-dimensional flow streamlines for (a) furrow flow $(\operatorname{Re}=21)$ and (b) zig-zag flow $(\operatorname{Re}=2100)[2]$.

Sarraf et al. [2] interpreted the flow in a corrugated channel by a two-dimensional illustration, as shown in Figure 15. In the figure, the solid lines represent the groove or flow direction on the front plate, while the dashed lines correspond to the ones on the backside plate of the channel. The intersections between the two types of lines characterize the contact points. In the furrow flow shown in Figure 15(a), the mainstream is in line with the gully of the corrugation until it arrives at the edge of the plate, where the fluid turns its way back along the corrugation curve of the opposite plate to the other edge. For the zig-zag flow in Figure 15(b), the fluid shifts direction between two contact points, following the corrugation shape of the walls from one plate to the adjacent one in 
the longitudinal direction of the PHE. The periodic disruption of the thermal boundary layer and the generation of swirl flow due to the mixing of these two flows, lead to heat transfer enhancement compared with the flat plates without chevron corrugation structures. With increasing $\beta$, the mixing between the two types of flows becomes stronger $[19,24,25]$, which causes better thermal performances.

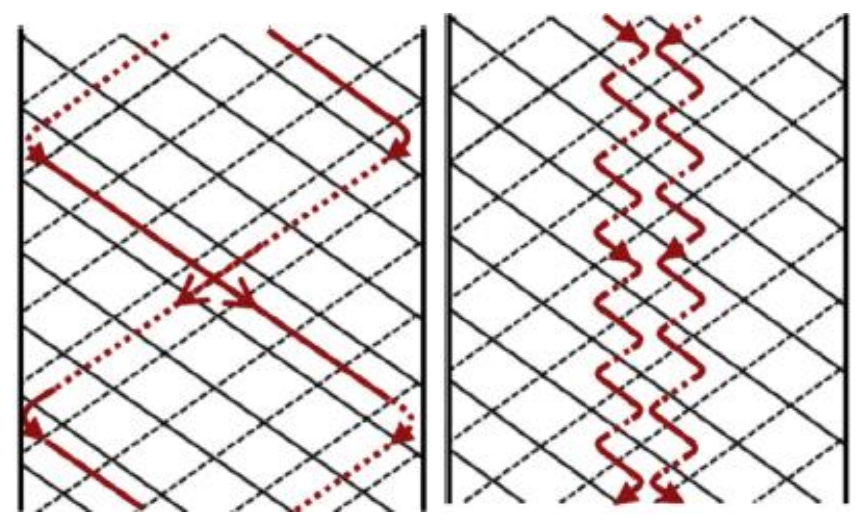

(a)

(b)

Figure 15 Two-dimensional flow structures for (a) zig-zag flow and (b) furrow flow [2].

Moreover, the dominance of the two flow components (zig-zag flow and furrow flow) is strongly dependent on the chevron angle. Namely, the furrow flow is dominant for small chevron angles, while the zig-zag component of the flow becomes increasingly significant as $\beta$ increases $[2,19,24,25,32,153]$. Compared with the furrow flow, more impingements of the fluid on the corrugation wall as well as more intense fluid separations and reattachments are generated in the zig-zag flow, which are beneficial for the energy exchange and result in more intensified heat transfer. The mechanism by which the chevron angle influences the flow pattern can be analyzed according to the fluid flow momentum shown in Figure 16. The momentum of the main flow $\boldsymbol{F}$ can be decomposed into two components, one along the corrugation $\boldsymbol{A}$, and the other perpendicular to the corrugation. The former is defined as:

$$
\boldsymbol{A}=\boldsymbol{F} \cos \beta
$$


With small $\beta, \boldsymbol{A}$ is large enough to overcome the resistance and drive the fluid flow along the corrugation. As $\beta$ increases, the component of the furrow flow is suppressed due to the decrease of $\boldsymbol{A}[153]$.

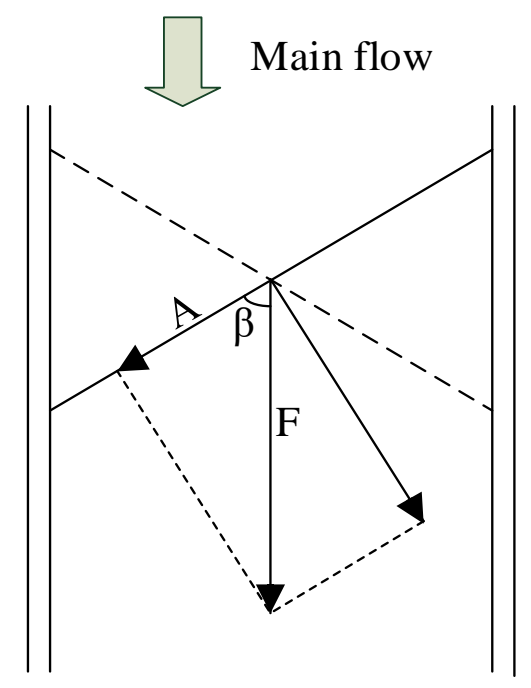

Figure 16 Diagram of fluid flow momentum.

Besides the chevron angle and the corrugation, the aspect ratio also has significant effect upon the thermal-hydraulic performance, i.e. the heat transfer coefficient and pressure drop both increase with the aspect ratio. A larger $\gamma$ (also $\beta$ ) corresponds to a higher effective flow length for both of the two types of flows, as well as a larger wetted surface area per unit of projected channel surface area [25], thereby leading to a better heat transfer performance and a higher pressure drop.

Compared with $\beta$ and $\gamma$, the plate dimension parameters are less influential. Generally, the heat transfer and pressure drop increase with the sharper corrugation, the decrease of plate size $\left(\mathrm{L} \times \mathrm{W}\right.$ or $\left.\mathrm{L}_{p} \times \mathrm{W}_{p}\right)$ and plate number, and the decrease of distance between plates.

\subsubsection{Effects of geometrical parameters on the two-phase heat transfer}

The research results generally agree that the pressure drop increases with the increase of $\beta$, while the effects of $\beta$ on heat transfer performance sometimes show contradictory results. In flow 
boiling and condensation processes, two main heat transfer mechanisms exist, namely, nucleate and convective boiling, and gravity-controlled and shear-controlled condensation, respectively. The convective boiling and shear-controlled condensation are characterized by "convection", i.e. the boiling/condensation is mainly realized through the convective heat transfer of fluids at the liquid-vapor interface. As analyzed previously, larger values of $\beta$ induce more turbulences, thereby enhancing the convective heat transfer. Therefore, in the convective boiling and shear-controlled condensation, the heat transfer coefficient increases with the increase of $\beta[63-65,67,68,70,73]$. Moreover, intensified heat transfer for larger $\beta$ triggers a more pronounced dryout effect, causing a sharper decrease of the heat transfer coefficient in the dryout region $[66,70]$. However, nucleate boiling dominates the flow boiling, so that the change in $\beta$ seems to affect weakly the nucleation of bubbles. Consequently, the heat transfer performance shows a weak dependence on $\beta$ [69]. There is a lack of studies regarding how $\beta$ influences the gravity-controlled condensation in the open literature. It is worth noting that the aforementioned conclusions to a large extent are based on physical interpretations; more numerical and experimental studies need to be conducted in order to obtain further evidence supporting these conclusions.

\subsubsection{Passive surface techniques}

The main enhancement mechanisms of passive surface techniques include boundary layer interruption, repeated developing flow, secondary flow (swirl flow) and fluid mixing, increased heat transfer area and impingement of fluids on the wall, which are similar to the effects of the chevron corrugation on single-phase heat transfer.

Specifically, for the first type of surface in Section 3.1.1 (the embossing surface), the various embossing types play a similar role as that of the vortex generators [77,82]. As concluded by Fiebig [154], three enhancement mechanisms of vortices are identified: i) developing boundary layers on the vortex generator surface, ii) swirl or rotation of the flow, and iii) flow destabilization 
and unsteadiness. Moreover, in the second type of surface (the secondary corrugated surface), the secondary corrugations are formed on the primary profile. The secondary corrugation could effectively modify the flow structure generated by the primary profile, and thus lead to a general increase of flow mixing [89-91]. Moreover, some unique flow characteristics could be created due to the different formations of secondary corrugation. For instance, the anti-phase secondary corrugation in Ref. [90] causes a moderate flow deceleration and a smaller peak velocity in the passage, which reduce energy dissipation. Finally, in the third type of surface (the roughened surface), the roughness causes a superposition effect by increasing the turbulence intensity and making the thermal boundary layer thinner.

Due to the different working conditions (working fluids and heat transfer regions) and the fact that different data reduction methods were used in the studies, it is difficult to compare the heat transfer performance of the PHEs using the different passive surface techniques. The amount of data that can be used for such comparison is limited; nevertheless, this paper makes an attempt by extracting several sets of heat transfer data from the studies with water used as the working fluid and with the Nusselt number and Reynolds number making up the criteria for the heat transfer performance and flow characteristic. Figure 17 presents the extracted data. The results suggest that the embossing-type surface $[77,82]$ has the highest Nusselt number compared with those of the other two types of surfaces, the secondary corrugated surface [91] and the roughened surface [96]. This may be attributed to the fact that the independent embossing induces higher turbulence intensity, more flow mixing, and more disruption and re-developing of the thermal boundary layer than the other types of surfaces. 


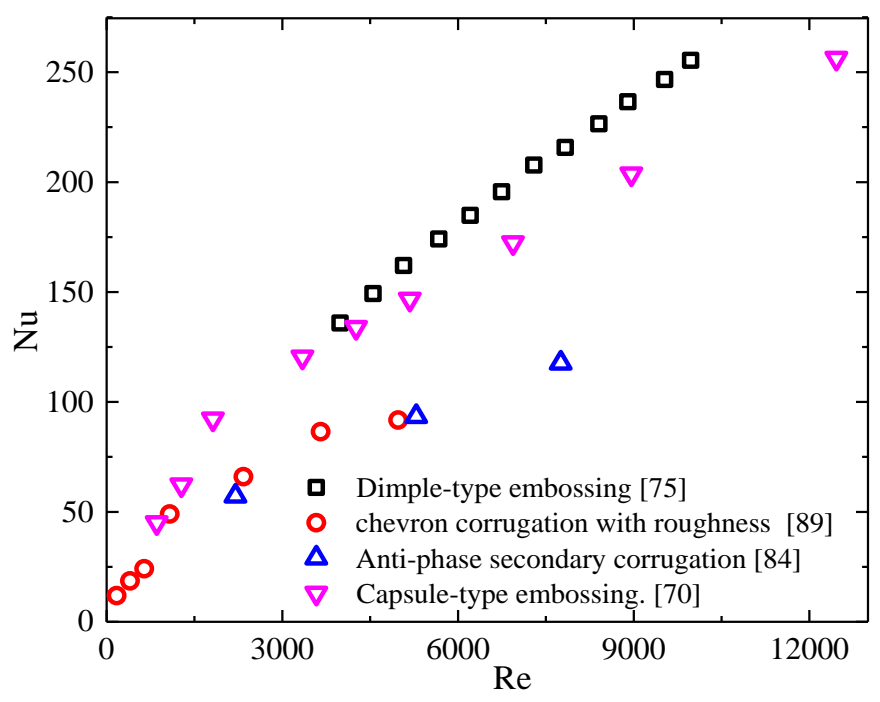

Figure 17 Comparison of heat transfer performance of single-phase water flow using passive surface techniques from the literature $[77,82,91,96]$.

The use of passive surface techniques in two-phase flow also shows potential to improve the heat transfer of PHEs compared with the conventional chevron corrugation PHE, i.e. previous results indicate an increase of 30-1000 \% by using different surface techniques [99-101]. Coincidentally, these three studies [99-101] suggest nucleate boiling to be the dominant heat transfer process, and hence the corresponding enhancement mechanism is attributed to the fact that such surface structures are beneficial for the nucleation of bubbles. For example, Furberg et al. [101] stated that the nano- and microporous surface structures used in their study ensured that the vapor produced during evaporation inside the structure could quickly be released due to the low resistance from the dendritic structure. Moreover, the high porosity of the interconnected network effectively traps vapor, facilitates liquid transport within the structure and allows for communication between active nucleation sites.

\subsubsection{Nanofluids}

Despite a few cases showing the deterioration of the heat transfer performance [141-144], the studies summarized in Table 4 present enhancement of the PHE thermal performance by using 
nanofluids as working fluids, especially in the case of a $49 \%$ increase in the Nusselt number with the CuO-EG nanofluid [111] and a $53 \%$ increase in the heat transfer coefficient with the MWCNT-water nanofluid [129]. The heat transfer mechanism of nanofluids can be considered as the compound effects of several factors. First, the change in the thermophysical properties of nanofluids compared with the base fluid influences the heat transfer process. As is well known, the increase in thermal conductivity improves the heat transfer performance. On the other hand, dispersed nanoparticles increase the effective viscosity of the fluid, which results in an increase of the thermal boundary layer thickness, and thus weakens the heat transfer. Therefore, in terms of the effect of thermophysical properties, both the positive effect of thermal conductivity enhancement and the negative effect of viscosity are significant. Secondly, a number of forces, such as the van der Waals force and Brownian force, which cause the irregular movement of particles, are proposed to be an important reason for heat transfer enhancement [155]. The collisions between nanoparticles and the walls, between nanoparticles and liquid molecules, as well as collisions among nanoparticles, which are induced by their chaotic movement, accelerate energy exchange. Moreover, the random movement of particles induces disturbances in the flow and thereby improves the turbulence intensity, enhancing the heat transfer process. Finally, the particle migration mechanism is considered as another reason for the heat transfer enhancement [156]. Due to the gradient distribution of shear stress in the axial direction of the channel, suspended particles tend to migrate from high shear rate regions to low shear rate regions. Based on the distribution of shear stress, a particle depletion region is formed near the wall. Therefore, the viscosity of the nanofluid is lower in that region, which causes a reduction of the boundary layer thickness and an increase in the heat transfer rate [156].

The effect of any characteristic parameters of nanofluids on heat transfer performance should correlate with the above-mentioned heat transfer mechanisms. The literature review indicates that 
the nanoparticle concentration and its type are the two governing parameters for the heat transfer performance. With the increase of concentration, both the thermal conductivity and viscosity of the nanofluid increase. In some cases, the comparison between the positive effect of thermal conductivity enhancement and the negative effect of viscosity is relevant. Refs. [124-127,133] have used this kind of comparison to explain the appearance of an optimum concentration, i.e. when $\varphi / \omega$ is lower than the optimum concentration, the positive effect of the thermal conductivity enhancement overcomes the negative effect of the increase in viscosity. Conversely, at concentrations higher than the optimum, the effect of the increase in viscosity on the heat transfer coefficient is more than the effect of the increase of thermal conductivity. Moreover, nanofluids composed of different types of nanoparticles have different thermophysical properties. According to the increases in thermal conductivity and viscosity of different nanofluids, the heat transfer will be influenced by the corresponding positive and negative effects. Besides, the effective particle diameters are different in the suspensions with various particle concentrations and types, causing differences in the chaotic movement of particles and migration effect. Specifically, particles with the smaller size have a higher chaotic movement velocity $[157,158]$ to accelerate energy exchange, while particles with larger size have more significance on the migration effect [159], inducing the thinner thermal boundary layer. The afore-mentioned analysis suggests that particle type (size, shape and property) and its concentration exert compound effects on the heat transfer performance. Furthermore, the complicated heat transfer mechanisms make it challenging to draw a general conclusion about the optimal nanoparticle type. As a result, several studies found different optimum nanoparticles, e.g. $\mathrm{CuO}$ by Abed et al. [116], $\mathrm{CeO}_{2}$ by Tawari et al. [125] and $\mathrm{Al}_{2} \mathrm{O}_{3}$ and $\mathrm{TiO}_{2}$ by Ham et al. [134].

The literature review suggests that, compared with relatively consistent results in macrochannels, where heat transfer increases with the increase of nanofluid concentration [159-168], the 
effect of concentration on the heat transfer in PHEs seems to be inconsistent. As outlined in Section 3.2.2, the effects of nanofluids on heat transfer performance in PHEs present not only the same phenomena as those of macro-channels, but also a non-monotonic increase of the heat transfer coefficient with concentration, resulting in the appearance of an optimum concentration. This behavior may be attributed to the interaction between the nanoparticles and the complex flow structure induced by the chevron corrugation. Taws et al. [142] emphasized that the internal flow structure is rather complex and often very tortuous because of the presence of corrugations of the adjacent plates [169], and nanoparticles modify the flow field, and, consequently, the thermal field. Furthermore, Pantzali et al. [141], Taws et al. [142] and Huang et al. [143] stated that turbulence intensity inside the PHE might be suppressed by adding nanoparticles, even a delay of laminarturbulence transition was found in Ref. [135]. It should be emphasized that the appearance of an optimum concentration was also found in mini/micro-channels [158,170,171], indicating that the effects of nanoparticles on the flow field in compact and irregular geometrical channels are more complex than that in regular macro-scale channels. The mechanism of the microscopical movement of nanoparticles in the sinusoidal channel of PHEs is still an open question. Moreover, with the increase in concentration, more particles exist per unit of volume. Consequently, the influence of volume concentration change on the particle distribution, particle chaotic movement and flow field inside the PHE deserves further investigations.

\subsection{Performance analysis}

From the literature review in Sections 2 and 3, it can be found that both the optimization of geometrical parameters of the chevron corrugation PHEs and the employment of enhancement techniques can improve the heat transfer at the expense of an increased pressure drop. Therefore, one needs to introduce an evaluation criterion for thermal-hydraulic performance, comprehensively comparing heat transfer and pressure drop characteristics. Such criterion makes it possible to 
compare the heat transfer performance of two heat exchangers (i.e. two chevron corrugation PHEs with different geometrical parameters and two PHEs with/without enhancement techniques) based on the same pumping power consumption.

Bergles et al. [172] and Webb [173] proposed several criteria to evaluate the thermal-hydraulic performance of the enhancement techniques. Bergles et al. [172] were first to outline a commonly used criterion, the performance evaluation criterion (PEC), and defined it as [174]

$$
P E C=\frac{N u_{e n} / N u_{r e f}}{\left(f_{e n} / f_{r e f}\right)^{1 / 3}},
$$

where $\mathrm{Nu}_{e n}$ and $f_{e n}$ are the Nusselt number and the friction factor, respectively, calculated for the heat exchanger with intensified geometrical parameters or enhancement techniques, while $\mathrm{Nu}_{r e f}$ and $f_{\text {ref }}$ are derived from the corresponding heat exchanger with reference geometrical parameters or without enhancement techniques. A PEC value greater than one indicates that the corresponding enhancement technique is able to improve the thermal-hydraulic performance.

\subsubsection{Performance comparison among the geometrical parameters}

Through extracting the available Nusselt number and friction factors from the literature, the PECs of the single-phase heat transfer studies were calculated with various geometrical parameters of the chevron corrugation PHEs $[32,33,35,39,50]$. The calculated PECs are plotted against the Reynolds number in Figure 18. In each group of the PEC calculations, the geometrical parameter of chevron corrugation with the lowest value was selected as the reference case. For example, three chevron angles, $60^{\circ}, 45^{\circ}$ and $30^{\circ}$, were employed from Ref. [32], and hence the $\beta=30^{\circ}$ was chosen as the reference case. As shown in Figure 18, the PEC is greater than one in most of the cases, indicating that the overall thermal-hydraulic performances can be improved by increasing the geometrical parameters of the chevron structure $(\beta$ and $\gamma / \eta)$. The corresponding ranges of the $\beta$, $\gamma$ and $\eta$ are $30-60^{\circ}, 0.071-0.5$ and $1.17-1.29$, respectively. The only opposite result [35] comes 
from the case in which the chevron angle is increased from $29^{\circ}$ to $85^{\circ}$ at high $\mathrm{Re}$ ranging from 19000 to 23000 . From Figure 18, it can be further found that thermal-hydraulic performances improve more significantly as $\beta$ increases from $30^{\circ}$ to $60^{\circ}$ compared with those of increasing $\beta$ from $30^{\circ}$ to $45^{\circ}$, demonstrated in two different studies [32,50]. Remarkably, PEC increases up to 1.4 at $\beta=60^{\circ}$ and $\operatorname{Re}=5000$ [32]. Therefore, a PHE with $\beta=60^{\circ}$ is recommended for the performance improvement based on the PEC analysis. Moreover, in the study with respect to $\gamma$ [32], by increasing $\gamma$ from 0.23 to 0.36 , the thermal-hydraulic performance improves, while there is no significant increase in the PEC with a further $\gamma$ increase from 0.36 to 0.5 . One sees another noteworthy improvement by increasing $\eta$ from 1.17 to 1.29 [39], in which the PEC increases up to 1.39 at $\operatorname{Re}=5000$, comparable with the best improvement result by changing $\beta$ from $30^{\circ}$ to $60^{\circ}$ [32]. However, the available research works are too limited to provide an accurate definition for the optimal $\beta$ and $\gamma / \eta$ based on the thermal-hydraulic performance. Therefore, further studies in this field aiming at defining the optimal geometry of chevron corrugation PHEs under different working conditions are recommended.

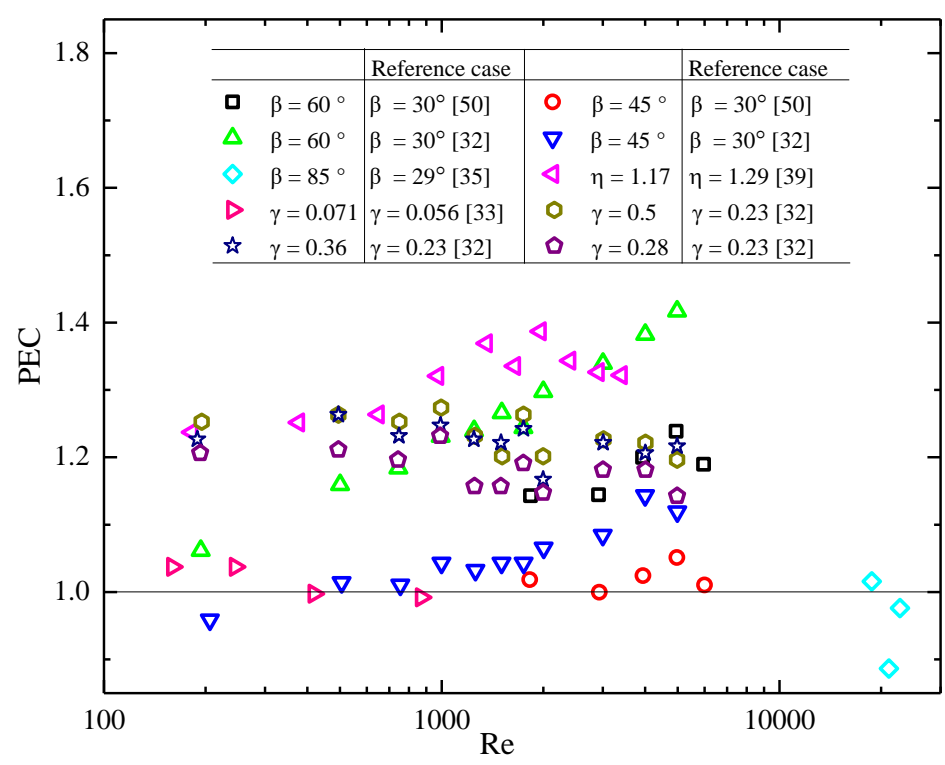

Figure 18 PEC of single-phase flow with different geometrical parameters of the chevron 
corrugation PHEs from literature [32,33,35,39,50].

\subsubsection{Performance comparison among the enhancement techniques}

The PECs of the heat transfer enhancement techniques, mainly referring to the surface passive techniques and the nanofluids, are plotted versus the Reynolds numbers in Figure 19. In these PEC calculations, the reference values $\mathrm{Nu}_{r e f}$ and $f_{r e f}$ were derived based on the smooth chevron corrugation PHEs with pure water as the working fluid in each study. As shown in Figure 19, all the six groups of available PEC values are greater than one, suggesting improvement of the heat transfer performance with the same pumping power consumption by using these enhancement techniques. From Figure 19, it can be further found that in the cases using the embossing surface [77], roughened surface, [95] and $\mathrm{Al}_{2} \mathrm{O}_{3}$-water [119] and $\mathrm{Cu}$-water nanofluids [122], the PEC ultimately decreases with the increase of Reynolds numbers, indicating that sharp increases of pressure drop prevail over increases in heat transfer coefficients with increasing Reynolds numbers. This result suggests that the enhancement techniques are more efficiently used at a low Reynolds number (e.g. $\operatorname{Re}<2000$ ), indicating that the flow resistance is a major constraint of further improving the thermal-hydraulic performance in PHEs using enhancement techniques. In addition, the embossing surface (capsule-type) and nanofluids $\left(\mathrm{Al}_{2} \mathrm{O}_{3^{-}}\right.$and $\mathrm{Cu}$-water) show the better potential on the improvement of thermal-hydraulic performance compared with the roughened chevron-type surface. The maximum values of PEC are about 2.1 and 1.9, obtained through the capsule-type embossing surface at $\mathrm{Re}=1900$ [77] and $1 \% \mathrm{Al}_{2} \mathrm{O}_{3}$-water nanofluid at $\mathrm{Re}=600$ [119], respectively, while the roughened chevron-type surface has the highest $\mathrm{PEC}=1.3$ at $\mathrm{Re}=$ 1000 [95]. Among the nanofluids, $0.2 \% \mathrm{Al}_{2} \mathrm{O}_{3}$-water [120] and $0.5 \% \mathrm{Cu}$-water [122] nanofluids have almost the same improvement results; however, compared with the $0.5 \% \mathrm{Cu}$-water nanofluid, $0.2 \% \mathrm{Al}_{2} \mathrm{O}_{3}$-water nanofluid has the better economy, due to the lower concentration as well as the use of a low-cost metallic oxide particle. Furthermore, $1 \% \mathrm{Al}_{2} \mathrm{O}_{3}$-water nanofluid in the study 
[119] has much higher PEC values than the others. In conclusion, the analysis indicates that $\mathrm{Al}_{2} \mathrm{O}_{3}$ is a promising nanoparticle for the heat transfer enhancement of single-phase flows in PHEs.

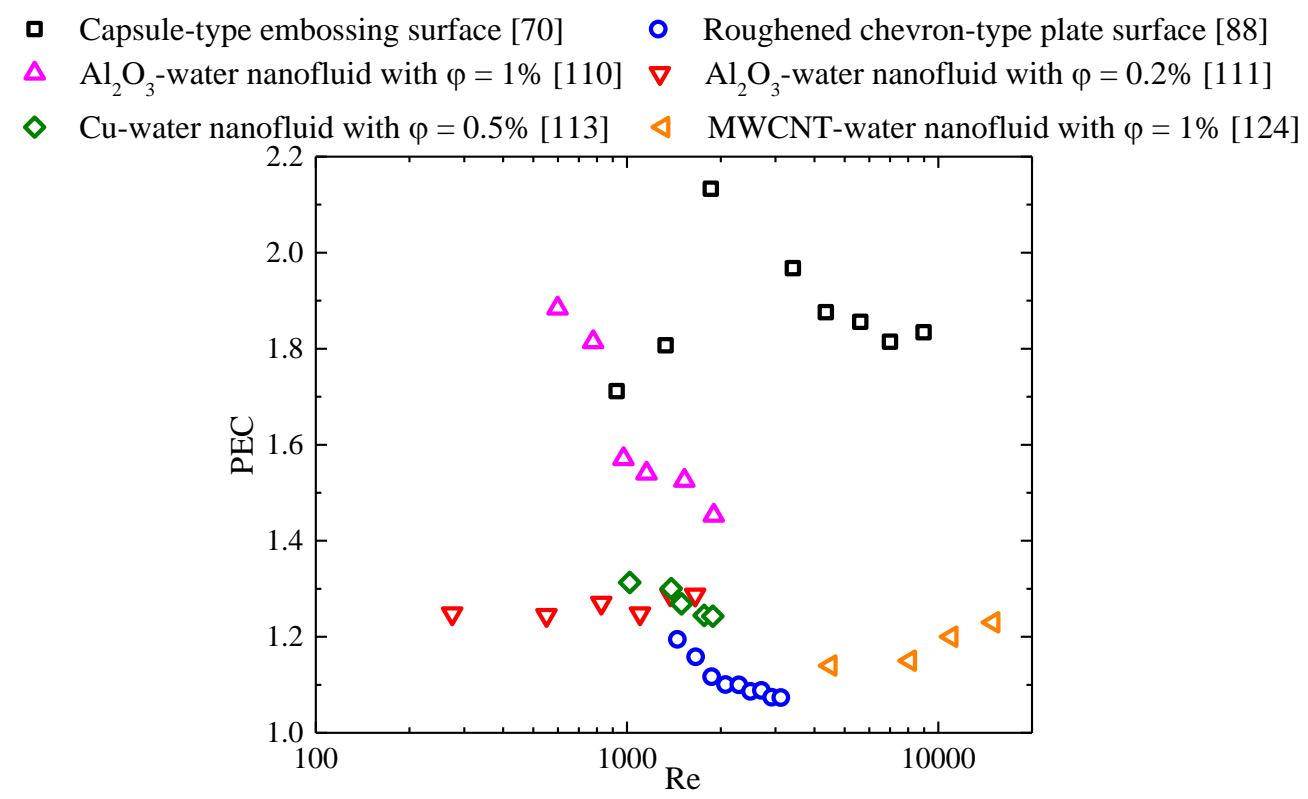

Figure 19 PEC of single-phase flow using passive surface techniques and nanofluids from the literature $[77,95,119,120,122,133]$.

\section{Research prospects}

As described previously, both the effect of geometrical parameters of chevron corrugation and the augmented mechanism of enhancement techniques are correlated with the flow structure and heat transfer mode in PHEs. For example, the current research results suggest that $\beta$ only greatly influences the flow boiling dominated by the convective boiling rather than the nucleate boiling. However, the results regarding determining the dominating heat transfer mechanism of flow boiling in PHEs are still contradictory in the open literature. Specifically, some studies [66,70,175-177] indicate that nucleate boiling and convective boiling are predominant at low and high vapor qualities, respectively. Conversely, Refs. $[69,178,179]$ suggest nucleate boiling to be the dominant flow boiling heat transfer mechanism for all vapor qualities. Therefore, there is the need for fundamental research of single-phase and two-phase heat transfers in the PHEs, aiming to improve 
the basic understanding of the heat transfer mechanism. This kind of fundamental research is of crucial importance for the selection of the most optimal enhancement technique, the application range for the enhancement technique, refinement of PHE empirical models and the optimized design of PHEs. The suggested fundamental research works include:

- In the single-phase heat transfer of chevron corrugation PHEs, the transitions between laminar and turbulent flows, and two main flow patterns, furrow flow and zig-zag flow, need to be accurately defined in various flow passages under different working conditions. Such analysis would be useful for selecting the most appropriate numerical modes when designing and optimizing PHEs.

- In the flow boiling heat transfer, future research works should be dedicated to realizing/identifying the detailed two-phase flow patterns in PHE channels under different working conditions. In addition, there is need for a proven quantified transition criterion to evaluate whether the evaporation process is nucleate boiling dominated or two-phase convective boiling dominated.

- The flow condensation in PHEs is a poorly investigated topic compared with flow boiling in PHEs. As noted in Ref. [169], since the use of PHEs in condensation has a relatively short history, the research on this topic is very limited so far and at this stage, theoretical predictions of heat transfer and pressure drop characteristics appear to be very difficult. Therefore, studies with respect to all aspects in this area are needed, especially research addressing the flow patterns of flow condensation in PHE channels.

From Figure 3(a) and Figure 4(a), one sees that the two-phase heat transfer compared with the single-phase heat transfer requires more attention. However, the use of PHEs as evaporators and condensers in refrigeration, air conditioning and power generation applications has become increasingly prevalent in the last 20 years [180], and thus there is the need for further studies aimed 
at improving the thermal-hydraulic performance of two-phase flow in PHEs. Firstly, the study of two-phase heat transfer involving different geometrical parameters of chevron corrugation other than the chevron angle, such as the $\gamma$ and $\eta$, is recommended. Secondly, more studies concerning enhancement techniques (e.g. different surface intensified structures) especially paying attention to diverse enhancement mechanisms in each two-phase heat transfer region (i.e. nucleate and convective boiling, and gravity-controlled and shear-controlled condensation) are suggested. From the presentation of the PECs of various enhancement techniques (see Figure 19), one identified research objective is to reduce the increased pressure drop of the enhancement techniques, since using enhancement techniques will improve the thermal-hydraulic performance of the PHEs at the high Re/large flow region.

It is interesting to develop the application of nanofluids in two-phase heat transfer in PHEs. While previous works indicate that there is a great potential to improve the thermal-hydraulic performance in the single-phase flow in PHEs, no application of nanofluids for two-phase flow in PHEs is available in the open literature. In a recent review of nanofluid boiling [181], experimental results suggest that in $66.7 \%$ of the cases of flow boiling using nanofluids, the heat transfer coefficient increases and in $33.3 \%$ it decreases, and in all the cases the critical heat flux is enhanced. Therefore, more research is needed to understand the fundamental heat transfer mechanisms of the use of nanofluids in PHEs, especially with respect to the interaction between nanoparticles and the complex flow induced by the chevron-corrugated surface. Results of such research are the key for the appropriate selections of nanoparticle type and concentration for its future commercialization. In addition, nanofluids have the potential to improve the thermal-hydraulic performance of heat transfer fluids, and it may also be worthwhile to study their potential to improve the performance of refrigeration systems, air conditioning systems, heat pumps, and power generation systems. 


\section{Conclusions}

This paper presented a review of the studies on the heat transfer enhancement techniques in plate heat exchangers, both for single-phase and two-phase flow conditions. The first part of the review (Section 2) focused on the effect of geometrical parameters on the performance of chevron corrugation plate heat exchangers. The second part (Section 3) reviewed the state-of-the-art of heat transfer enhancement techniques in plate heat exchangers. In section 4 , the mechanisms under different heat transfer processes were analyzed and a comprehensive evaluation and comparison of the thermal-hydraulic performances of plate heat exchangers with various geometrical parameters and enhancement techniques was provided. Moreover, using the available data in the open literature, the performance evaluation criteria of the chevron corrugation plate heat exchangers were calculated with various geometrical parameters and the different heat transfer enhancement techniques.

The review indicates that for chevron corrugation plate heat exchangers, the chevron angle is the most influential geometrical parameter. In the single-phase heat transfer, both the heat transfer and pressure drop increase with the increase of the chevron angle. In addition, the aspect ratio of the chevron corrugation also has a significant effect on the heat transfer and pressure drop, as both of them increase with the increase of the aspect ratio. Further studies aiming at defining the optimum chevron angle and aspect ratio are recommended. In the two-phase flow regime, the chevron angle has a significant influence on the heat transfer regions characterized by convection, such as convective boiling and shear-controlled condensation. The experimental results of most of the relevant works suggest that the increase of the chevron angle increases the two-phase heat transfer coefficient.

Passive surface techniques and the use of nanofluids are the two most commonly applied enhancement techniques for plate heat exchangers. These methods augment the heat transfer 
performance, accompanied with increased pressure losses. For the passive surface techniques applied in the single-phase heat transfer, the embossing surface shows a higher intensified heat transfer performance than the secondary corrugated surface and the roughened surface. In the twophase flow, the employment of passive surface techniques can significantly enhance the heat transfer by providing more nucleation sites for bubble/droplet formation. The microstructured surface with the nano- and microporous layer leads to a ten-fold increase in flow boiling heat transfer coefficient. When applying nanofluids in plate heat exchangers, several phenomena normally not occurring in macro-scale tubes occur, including the appearance of an optimum concentration and, in some conditions, the degradation of the heat transfer performance. Despite the advanced performances shown in these typical enhancement techniques, their technical and economical feasibilities require further evaluation before their commercialization.

The performance evaluation criteria indicate that for the chevron corrugation PHEs, increasing the values of the geometrical parameters within the range of $\beta=30^{\circ}-60^{\circ}, \gamma=0.071-0.5$ and $\eta=$ 1.17-1.29 allows improving the thermal-hydraulic performance. Among the enhancement techniques, the capsule-type embossing surface [77] has the maximum performance evaluation criteria of 2.1. With respect to nanofluids, $1 \% \mathrm{Al}_{2} \mathrm{O}_{3}$-water nanofluid indicates the maximum performance evaluation criteria of 1.9 at a Reynolds number equal to 600 .

Based on the reviewed literature and the analyses, several future research areas are recommended: i) fundamental understanding of thermo-physical phenomena of single-phase and two-phase heat transfers in chevron corrugation plate heat exchanger; ii) thermal-hydraulic performance improvement of the two-phase heat transfer in plate heat exchangers, by changing the geometrical parameters of chevron corrugation or using heat transfer enhancement techniques; iii) enhancement techniques which not only improve the heat transfer performance but also are able to suppress the increase of pressure drop caused by themselves; and iv) mechanism study of the 
nanofluid flow and heat transfer in plate heat exchangers and further investigations on the relevant application of nanofluids in thermodynamic cycles.

\section{Acknowledgement}

The research presented in this paper has received funding from the People Programme (Marie Curie Actions) of the European Union's Seventh Framework Programme (FP7/2007-2013) under the REA grant agreement $\mathrm{n}^{\circ} 609405$ (COFUNDPostdocDTU), and Innovationsfonden with the THERMCYC project (www.thermcyc.mek.dtu.dk, project ID: 1305-00036B). The financial support is gratefully acknowledged. 


\section{References}

[1] Wang L, Sundén B, Manglik RM. Plate Heat Exchangers: Design, Applications and Performance. Southampton, UK: WIT Press; 2007.

[2] Sarraf K, Launay S, Tadrist L. Complex 3D-flow analysis and corrugation angle effect in plate heat exchangers. Int J Therm Sci 2015;94:126-38. doi:10.1016/j.ijthermalsci.2015.03.002.

[3] Thulukkanam K. Heat Exchanger Design Handbook. Second Ed. New York, NY: CRC Press; 2013.

[4] Martin H. A theoretical approach to predict the performance of chevron-type plate heat exchangers. Chem Eng Process 1996;35:301-10.

[5] Amalfi RL, Vakili-Farahani F, Thome JR. Flow boiling and frictional pressure gradients in plate heat exchangers. Part 1: Review and experimental database. Int J Refrig 2016;61:16684. doi:10.1016/j.ijrefrig.2015.07.010.

[6] Reay D, Ramshaw C, Harve A. Process intensification: engineering for efficiency, sustainability and flexibility. Second Edi. Elsevier Ltd; 2013.

[7] Bergles AE. Handbook of Heat Transfer. 3rd editio. New York, NY: McGraw-Hill; 1998.

[8] Bergles AE. The Implications and Challenges of Enhanced Heat Transfer for the Chemical Process Industries. Chem Eng Res Des 2001;79:437-44. doi:10.1205/026387601750282562.

[9] Shon BH, Jeon SW, Kim Y, Kang YT. Review: Condensation and Evaporation Characteristics of Low GWP Refrigerants in Plate Heat Exchangers. Int J Air-Conditioning Refrig 2016;24:1630004. doi:10.1142/S2010132516300044.

[10] Eldeeb R, Aute V, Radermacher R. A survey of correlations for heat transfer and pressure 
drop for evaporation and condensation in plate heat exchangers. Int J Refrig 2016;65:12-26. doi:10.1016/j.ijrefrig.2015.11.013.

[11] Khan TS, Khan MS, Chyu MC, Ayub ZH, Chattha JA. Review of heat transfer and pressure drop correlations for evaporation of fluid flow in plate heat exchangers (RP-1352). HVAC R Res 2009;15:169-88. doi:10.1080/10789669.2009.10390832.

[12] Palm B, Claesson J. Plate heat exchangers: Calculation methods for singleand two-phase flow. Heat Transf Eng 2006;27:88-98. doi:10.1080/01457630500523949.

[13] Ayub ZH. Plate heat exchanger literature survey and new heat transfer and pressure drop correlations for refrigerant evaporators. Heat Transf Eng 2003;24:3-16. doi:10.1080/01457630304056.

[14] Reppich M. Use of high performance plate heat exchangers in chemical and process industries. Int J Therm Sci 1999;38:999-1008. doi:10.1016/S1290-0729(99)00109-X.

[15] Abu-Khader MM. Plate heat exchangers: Recent advances. Renew Sustain Energy Rev 2012;16:1883-91. doi:10.1016/j.rser.2012.01.009.

[16] Abou Elmaaty TM, Kabeel AE, Mahgoub M. Corrugated plate heat exchanger review. Renew Sustain Energy Rev 2017;70:852-60. doi:10.1016/j.rser.2016.11.266.

[17] Kumar V, Tiwari AK, Ghosh SK. Application of nanofluids in plate heat exchanger: A review. Energy Convers Manag 2015;105:1017-36. doi:10.1016/j.enconman.2015.08.053.

[18] Focke WW. Turbulent convective transfer in plate heat exchangers. Int Commun Heat Mass Transf 1983;10:201-10. doi:10.1016/0735-1933(83)90005-2.

[19] Focke WW, Zachariades J, Olivier I. The effect of the corrugation inclination angle on the thermohydraulic performance of plate heat exchangers. Int J Heat Mass Transf 
1985;28:1469-79. doi:10.1016/0017-9310(85)90249-2.

[20] Muley A, Manglik RM. Enhanced heat transfer characteristics of single-phase flows in a plate heat exchanger with mixed chevron plates. Enhanc Heat Transf 1997;4:187-201.

[21] Muley A, Manglik RM, Metwally HM. Enhanced Heat Transfer Characteristics of Viscous Liquid Flows in a Chevron Plate Heat Exchanger. J Heat Transfer 1999;121:1011-7. doi:10.1115/1.2826051.

[22] Li Y, Hessami M, Hu EJ. Experimental investigation of heat transfer and pressure drop in cross-corrugated plate heat exchangers. Proc. Int. Conf. Energy Environ., Shanghai, China: 1998, p. 288-93. doi:10.1081/E-EEE2-120046011.

[23] Hessami M. An experimental investigation of the performance of cross-corrugated plate heat exchangers. J Enhanc Heat Transf 2003;10:379-93. doi:10.1615/JEnhHeatTransf.v10.i4.30.

[24] Dovic, Svaic. Influence of chevron plates geometry on performances of plate heat exchangers. Teh Vjesn 2007;14:37-45.

[25] Dović D, Palm B, Švaić S. Generalized correlations for predicting heat transfer and pressure drop in plate heat exchanger channels of arbitrary geometry. Int J Heat Mass Transf 2009;52:4553-63. doi:10.1016/j.ijheatmasstransfer.2009.03.074.

[26] Kanaris AG, Mouza AA, Paras S V. Optimal design of a plate heat exchanger with undulated surfaces. Int J Therm Sci 2009;48:1184-95. doi:10.1016/j.ijthermalsci.2008.11.001.

[27] Kanaris AG, Mouza AA, Paras SV. Flow and Heat Transfer in Narrow Channels with Corrugated Walls. Chem Eng Res Des 2005;83:460-8. doi:10.1205/cherd.04162.

[28] Kanaris AG, Mouza AA, Paras S V. Flow and Heat Transfer Prediction in a Corrugated Plate Heat Exchanger using a CFD Code. Chem Eng Technol 2006;29:923-30. 
doi:10.1002/ceat.200600093.

[29] Khan TS, Khan MS, Chyu MC, Ayub ZH. Experimental investigation of single phase convective heat transfer coefficient in a corrugated plate heat exchanger for multiple plate configurations. Appl Therm Eng 2010;30:1058-65.

doi:10.1016/j.applthermaleng.2010.01.021.

[30] Han W, Saleh K, Aute V, Ding G, Hwang Y, Radermacher R. Numerical simulation and optimization of single-phase turbulent flow in chevron-type plate heat exchanger with sinusoidal corrugations. HVAC\&R Res 2011;17:186-97.

[31] Lee J, Lee KS. Friction and Colburn factor correlations and shape optimization of chevrontype plate heat exchangers. Appl Therm Eng 2015;89:62-9.

doi:10.1016/j.applthermaleng.2015.05.080.

[32] Lee J, Lee K-S. Flow characteristics and thermal performance in chevron type plate heat exchangers. Int J Heat Mass Transf 2014;78:699-706.

doi:10.1016/j.ijheatmasstransfer.2014.07.033.

[33] Blomerius H, Hölsken C, Mitra NK. Numerical Investigation of Flow Field and Heat Transfer in Cross-Corrugated Ducts. J Heat Transfer 1999;121:314-21.

[34] Muley A, Manglik RM. Experimental Study of Turbulent Flow Heat Transfer and Pressure Drop in a Plate Heat Exchanger With Chevron Plates. J Heat Transfer 1999;121:110. doi:10.1115/1.2825923.

[35] Vafajoo L, Moradifar K, Hosseini SM, Salman BH. Mathematical modelling of turbulent flow for flue gas-air Chevron type plate heat exchangers. Int J Heat Mass Transf 2016;97:596-602. doi:10.1016/j.ijheatmasstransfer.2016.02.035. 
[36] Luan ZJ, Zhang GM, Tian MC, Fan. MX. Flow resistance and heat transfer characteristics of a new-type plate heat exchanger. J Hydrodyn Ser B 2008;20:524-9. doi:10.1016/S10016058(08)60089-X.

[37] Zhang L, Che D. Influence of corrugation profile on the thermalhydraulic performance of cross-corrugated plates. Numer Heat Transf Part A Appl 2011;59:267-96. doi:10.1080/10407782.2011.540963.

[38] Lam C, Bremhorst K. A Modified Form of the k- $\varepsilon$ Model for Predicting Wall Turbulence. J Fluids Eng 1981;103:456-60. doi:doi:10.1115/1.3240815.

[39] Gulenoglu C, Akturk F, Aradag S, Sezer Uzol N, Kakac S. Experimental comparison of performances of three different plates for gasketed plate heat exchangers. Int J Therm Sci 2014;75:249-56. doi:10.1016/j.ijthermalsci.2013.06.012.

[40] Yang J, Jacobi A, Liu W. Heat transfer correlations for single-phase flow in plate heat exchangers based on experimental data. Appl Therm Eng 2017;113:1547-57. doi:10.1016/j.applthermaleng.2016.10.147.

[41] Faizal M, Ahmed MR. Experimental studies on a corrugated plate heat exchanger for small temperature difference applications. Exp Therm Fluid Sci 2012;36:242-8. doi:10.1016/j.expthermflusci.2011.09.019.

[42] Torii S. Flow Visualization and Thermal-Fluid Flow Phenomenon in Single Plate Heat Exchanger with Various Plate Shapes Formed by Shock Processing Method. Mater Sci Forum 2011;673:35-9. doi:10.4028/www.scientific.net/MSF.673.35.

[43] Hwang IJ, Yamamoto T, Torii S. Study on the Plate Surface Flow in the Separable Herringbone Type Plate Heat Exchanger. Int J Earth Sci Eng 2014;07:540-4. 
[44] Exchangers PH. Effects of wavelength and inclination angle on the homogeneity of local heat transfer coefficients in plate heat exchangers 1998;6:203-8.

[45] Lee YS, Su CC, Sun YM, Ye JC. Experimental study in heat transfer in wavy channels. J Enhanc Heat Transf 2003;12:21-9.

[46] Lin JH, Huang CY, Su CC. Dimensional analysis for the heat transfer characteristics in the corrugated channels of plate heat exchangers. Int Commun Heat Mass Transf 2007;34:30412. doi:10.1016/j.icheatmasstransfer.2006.12.002.

[47] Wang DB, Liang ZX, Zhou JJ, Wang H Bin. The Simulation Research on the Performance of Chevron-Type Corrugated Plate Heat Exchanger. Adv Mater Res 2011;383-390:6502-7. doi:10.4028/www.scientific.net/AMR.383-390.6502.

[48] Wang Q-W, Zhang D-J, Xie G-N. Experimental Study and Genetic-Algorithm-Based Correlation on Pressure Drop and Heat Transfer Performances of a Cross-Corrugated Primary Surface Heat Exchanger. J Heat Transfer 2009;131:061802. doi:10.1115/1.3090716.

[49] Guo CS, Du WJ, Cheng L. Characteristics of heat transfer and resistance of double chevron plate heat exchanges with different corrugation pitch. Adv Intell Soft Comput 2012;143 AISC:169-74. doi:10.1007/978-3-642-27966-9_24.

[50] Shaji K, Das SK. Effect of Plate Characteristics on Axial Dispersion and Heat Transfer in Plate Heat Exchangers. J Heat Transfer 2013;135:041801. doi:10.1115/1.4022993.

[51] Zhao YH, Wu YF, Cheng HJ, Zhu GL. Numerical Simulation of Corrugated Depth on the Performance of Plate Heat Exchanger. Adv Mater Res 2013;860-863:696-9. doi:10.4028/www.scientific.net/AMR.860-863.696.

[52] Hajabdollahi F, Hajabdollahi Z, Hajabdollahi H. Optimum design of gasket plate heat 
exchanger using multimodal genetic algorithm. Heat Transf Res 2013;44:761-89.

[53] Zhao Y, Cheng H, Wu Y, Zhu G. Numerical simulation of corrugated inclination angle on the performance of plate heat exchanger. Proc. 2014 Int. Conf. Mechatronics, Electron. Ind. Control Eng., Shenyang, China: 2014, p. 1268-71.

[54] Kan M, Ipek O, Gurel B. Plate heat exchangers as a compact design and optimization of different channel angles. Acta Phys Pol A 2015;128:49-52. doi:10.12693/APhysPolA.128.B49.

[55] Krishna M, Swamy M, Manjunath G, Rao N, Rao B, Murthy P. Heat Transfer Enhancement in Corrugated Plate Heat Exchanger. Br J Appl Sci Technol 2016;18:1-14. doi:10.9734/BJAST/2016/28438.

[56] Kılıç B, İpek O. Experimental investigation of heat transfer and effectiveness in corrugated plate heat exchangers having different chevron angles. Heat Mass Transf 2017;53:725-31. doi:10.1007/s00231-016-1817-2.

[57] Najafi H, Najafi B. Multi-objective optimization of a plate and frame heat exchanger via genetic algorithm. Heat Mass Transf Und Stoffuebertragung 2010;46:639-47. doi:10.1007/s00231-010-0612-8.

[58] Kumar B, Singh SN. Hydraulic Performance Study of a Chevron Type Plate Heat Exchanger. Therm Sci 2016;00:312-312.

[59] Kim MB, Park CY. An experimental study on single phase convection heat transfer and pressure drop in two brazed plate heat exchangers with different chevron shapes and hydraulic diameters. J Mech Sci Technol 2017;31:2559-71. doi:10.1007/s12206-017-0454-0.

[60] Zhicheng Y, Lijun W, Zhaokuo Y, Haowen L. Shape optimization of welded plate heat 
exchangers based on grey correlation theory. Appl Therm Eng 2017;123:761-9. doi:10.1016/j.applthermaleng.2017.05.005.

[61] Kumar B, Soni A, Singh SN. Effect of geometrical parameters on the performance of chevron type plate heat exchanger. Exp Therm Fluid Sci 2018;91:126-33. doi:10.1016/j.expthermflusci.2017.09.023.

[62] Dutta OY, Nageswara Rao B. Investigations on the performance of chevron type plate heat exchangers. Heat Mass Transf Und Stoffuebertragung 2018;54:227-39. doi:10.1007/s00231017-2107-3.

[63] Han DH, Lee KJ, Kim YH. Experiments on the characteristics of evaporation of R410A in brazed plate heat exchangers with different geometric configurations. Appl Therm Eng 2003;23:1209-25. doi:10.1016/S1359-4311(03)00061-9.

[64] Han DH, Lee KJ, Kim YH. The characteristics of condensation brazed plate heat exchangers with different chevron angles. J Korean Phys Soc 2003;43:66-73. doi:10.1016/S13594311(03)00061-9.

[65] Würfel R, Ostrowski N. Experimental investigations of heat transfer and pressure drop during the condensation process within plate heat exchangers of the herringbone-type. Int J Therm Sci 2004;43:59-68. doi:10.1016/S1290-0729(03)00099-1.

[66] Djordjevic E, Kabelac S. Flow boiling of R134a and ammonia in a plate heat exchanger. Int J Heat Mass Transf 2008;51:6235-42. doi:10.1016/j.ijheatmasstransfer.2008.01.042.

[67] Hayes N, Jokar A, Ayub ZH. Study of carbon dioxide condensation in chevron plate exchangers; Heat transfer analysis. Int J Heat Mass Transf 2011;54:1121-31. doi:10.1016/j.ijheatmasstransfer.2010.11.010. 
[68] Hayes N, Jokar A, Ayub ZH. Study of carbon dioxide condensation in chevron plate exchangers; Pressure drop analysis. Int J Heat Mass Transf 2012;55:2916-25. doi:10.1016/j.ijheatmasstransfer.2012.02.013.

[69] Huang J, Sheer TJ, Bailey-Mcewan M. Heat transfer and pressure drop in plate heat exchanger refrigerant evaporators. Int J Refrig 2012;35:325-35. doi:10.1016/j.ijrefrig.2011.11.002.

[70] Khan MS, Khan TS, Chyu MC, Ayub ZH. Evaporation heat transfer and pressure drop of ammonia in a mixed configuration chevron plate heat exchanger. Int J Refrig 2014;41:92102. doi:10.1016/j.ijrefrig.2013.12.015.

[71] Khan TS, Khan MS, Chyu MC, Ayub ZH. Experimental investigation of evaporation heat transfer and pressure drop of ammonia in a 60?? chevron plate heat exchanger. Int. J. Refrig., vol. 35, Elsevier; 2012, p. 336-48. doi:10.1016/j.ijrefrig.2011.10.018.

[72] Khan MS, Khan TS, Chyu MC, Ayub ZH. Experimental investigation of evaporation heat transfer and pressure drop of ammonia in a 30?? chevron plate heat exchanger. Int. J. Refrig., vol. 35, Elsevier; 2012, p. 1757-65. doi:10.1016/j.ijrefrig.2012.05.019.

[73] Müller A, Kabelac S. The experimental determination of heat transfer and pressure drop during condensation in a plate heat exchanger with corrugated plates. WIT Trans Eng Sci 2014;83:337-49. doi:10.2495/HT140301.

[74] Imran M, Usman M, Yang Y, Park BS. Flow boiling of R245fa in the brazed plate heat exchanger: Thermal and hydraulic performance assessment. Int J Heat Mass Transf 2017;110:657-70. doi:10.1016/j.ijheatmasstransfer.2017.03.070.

[75] Kim D, Lee DC, Jang DS, Jeon Y, Kim Y. Comparative evaluation of flow boiling heat 
transfer characteristics of R-1234ze(E) and R-134a in plate heat exchangers with different Chevron angles. Appl Therm Eng 2018;132:719-29.

doi:10.1016/j.applthermaleng.2018.01.019.

[76] Miyata K, Mori H, Taniguchi T, Umezawa S, Sugita K. Effect of the Chevron Angle on Cooling Heat Transfer Characteristics of Supercritical Pressure Fluids in Plate Heat Exchangers. Heat Transf Eng 2018;0:1-16. doi:10.1080/01457632.2018.1450334.

[77] Zhang Y, Jiang C, Yang Z, Zhang Y, Bai B. Numerical study on heat transfer enhancement in capsule-type plate heat exchangers. Appl Therm Eng 2016;108:1237-42. doi:10.1016/j.applthermaleng.2016.08.033.

[78] Li WZ, Yan YY, Shen S, Hai Y. An investigation on heat transfer performance of a new type of plate heat exchanger with dimples. IMechE Conf Trans 1999;7:19-25.

[79] Ji C, Wu L, Li J, Wang X. Experimental research on heat transfer characteristics of Dimple plate heat exchanger. 5th Int. Conf. Adv. Des. Manuf. Eng., Shengzhen, China: 2015, p. 97983. doi:10.1115/HT2008-56203.

[80] Alqutub AM, Linjawim MT, Alrawi IM. Performance study of a dimpled-protruded air-to-air plate heat exchanger. Proc. ASME 2015 Power Conf., San Diego, California: 2015, p. 1-8.

[81] Du W, Wang F, Xin G, Zhang S, Cheng L. Numerical investigation and thermodynamic analysis of a novel regular hexagonal plate heat exchanger. Proc. 14th Int. Heat Transf. Conf., Washington, DC, USA: 2010, p. 1-7.

[82] Song J, Wang F, Cheng L. Experimental study and analysis of a novel multi-media plate heat exchanger. Sci China Technol Sci 2012;55:2157-62. doi:10.1007/s11431-012-4931-5.

[83] Jeong JY, Hong H ki, Kim SK, Kang YT. Impact of plate design on the performance of 
welded type plate heat exchangers for sorption cycles. Int J Refrig 2009;32:705-11. doi:10.1016/j.ijrefrig.2009.01.028.

[84] Durmuş A, Benli H, Kurtbaş İ, Gül H. Investigation of heat transfer and pressure drop in plate heat exchangers having different surface profiles. Int J Heat Mass Transf 2009;52:1451-7. doi:10.1016/j.ijheatmasstransfer.2008.07.052.

[85] Azhagcsan N, Balachandran P, Haq AN. Heat transfer characteristics and pressure drop in bubble finned plate heat exchanger and correlation development. Int J Heat Technol $2007 ; 25: 1-8$

[86] Villanueva HHS, de Mello PEB. Heat transfer and pressure drop correlations for finned plate ceramic heat exchangers. Energy 2015;88:118-25. doi:10.1016/j.energy.2015.04.017.

[87] Monteiro DB, de Mello PEB. Thermal performance and pressure drop in a ceramic heat exchanger evaluated using CFD simulations. Energy 2012;45:489-96. doi:10.1016/j.energy.2012.02.012.

[88] Zhang C, Wang D, Han Y, Zhu Y, Peng X. Experimental and numerical investigation on the exergy and entransy performance of a novel plate heat exchanger. Exp Heat Transf 2017;30:162-77. doi:10.1080/08916152.2016.1179358.

[89] Kim M, Baik YJ, Park SR, Ra HS, Lim H. Experimental study on corrugated cross-flow aircooled plate heat exchangers. Exp Therm Fluid Sci 2010;34:1265-72. doi:10.1016/j.expthermflusci.2010.05.007.

[90] Doo JH, Ha MY, Min JK, Stieger R, Rolt A, Son C. An investigation of cross-corrugated heat exchanger primary surfaces for advanced intercooled-cycle aero engines (Part-I: Novel geometry of primary surface). Int J Heat Mass Transf 2012;55:5256-67. 
doi:10.1016/j.ijheatmasstransfer.2013.01.084.

[91] Doo JH, Ha MY, Min JK, Stieger R, Rolt A, Son C. An investigation of cross-corrugated heat exchanger primary surfaces for advanced intercooled-cycle aero engines (Part-II: Design optimization of primary surface). Int J Heat Mass Transf 2013;61:138-48. doi:10.1016/j.ijheatmasstransfer.2013.01.084.

[92] Lee JM, Kwan PW, Son CM, Ha MY. Characterizations of aerothermal performance of novel cross-corrugated plate heat exchangers for advanced cycle aero-engines. Int $\mathbf{J}$ Heat Mass Transf 2015;85:166-80. doi:10.1016/j.ijheatmasstransfer.2015.01.127.

[93] Luan Z, Zhang G, Tian M, Fan M. Flow resistance and heat transfer characteristics of a newtype plate heat exchanger. J Hydrodyn 2008;20:524-9.

[94] Cao X, Du W, Zhang G, Cheng L. A numerical study of the plate heat exchanger with compound corrugations in the condition of low Reynolds number and high Prandtl number. Proc. 14th Int. Heat Transf. Conf., Washington, DC, USA: 2010.

[95] Nilpueng K, Wongwises S. Experimental study of single-phase heat transfer and pressure drop inside a plate heat exchanger with a rough surface. Exp Therm Fluid Sci 2015;68:26875. doi:10.1016/j.expthermflusci.2015.04.009.

[96] Wajs J, Mikielewicz D. Effect of Surface Roughness on Thermal-Hydraulic Characteristics of Plate Heat Exchanger. Key Eng Mater 2013;597:63-74. doi:10.4028/www.scientific.net/KEM.597.63.

[97] Wajs J, Mikielewicz D. Influence of metallic porous microlayer on pressure drop and heat transfer of stainless steel plate heat exchanger. Appl Therm Eng 2016;93:1337-46. doi:10.1016/j.applthermaleng.2015.08.101. 
[98] Nilpueng K, Keawkamrop T, Ahn HS, Wongwises S. Effect of chevron angle and surface roughness on thermal performance of single-phase water flow inside a plate heat exchanger. Int Commun Heat Mass Transf 2018;91:201-9. doi:10.1016/j.icheatmasstransfer.2017.12.009.

[99] Matsushima H, Uchida M. Evaporation performance of a plate heat exchanger embossed with pyramid-Like structures. J Enhanc Heat Transf 2002;9:10.

[100] Longo GA, Gasparella A, Sartori R. Experimental heat transfer coefficients during refrigerant vaporisation and condensation inside herringbone-type plate heat exchangers with enhanced surfaces. Int J Heat Mass Transf 2004;47:4125-36. doi:10.1016/j.ijheatmasstransfer.2004.05.001.

[101] Furberg R, Palm B, Li S, Toprak M, Muhammed M. The Use of a Nano- and Microporous Surface Layer to Enhance Boiling in a Plate Heat Exchanger. J Heat Transfer 2009;131:101010. doi:10.1115/1.3180702.

[102] Soontarapiromsook J, Mahian O, Dalkilic AS, Wongwises S. Effect of surface roughness on the condensation of R-134a in vertical chevron gasketed plate heat exchangers. Exp Therm Fluid Sci 2018;91:54-63. doi:10.1016/j.expthermflusci.2017.09.015.

[103] Choi SUS, Eastman JA. Enhancing thermal conductivity of fluids with nanoparticles. ASME FED 1995:99-105.

[104] Sarafraz MM, Hormozi F. Convective boiling and particulate fouling of stabilized CuOethylene glycol nanofluids inside the annular heat exchanger. Int Commun Heat Mass Transf 2014;53:116-23. doi:10.1016/j.icheatmasstransfer.2014.02.019.

[105] Zhang J, Diao YH, Zhao YH, Tang X, Yu WJ, Wang S. Experimental study on the heat 
recovery characteristics of a new-type flat micro-heat pipe array heat exchanger using nanofluid. Energy Convers Manag 2013;75:609-16. doi:10.1016/j.enconman.2013.08.003.

[106] Timofeeva E V, Routbort JL, Singh D. Particle shape effects on thermophysical properties of alumina nanofluids. J Appl Phys 2009;106:014304. doi:10.1063/1.3155999.

[107] Sharma KV, Suleiman A, Hassan HJ, Suhaimi B, Hegde G. Engineering Applications of Nanotechnology. Spring; 2017.

[108] Prasher R, Phelan PE, Bhattacharya P. Effect of aggregation kinetics on the thermal conductivity of nanoscale colloidal solutions (nanofluid). Nano Lett 2006;6:1529-34. doi:10.1021/n1060992s.

[109] Hamilton RL, Crosser OK. Thermal conductivity of heterogeneous two-component systems. Ind Eng Chem Fundam 1962;1:187-91. doi:10.1021/i160003a005.

[110] Ho CJ, Chen MW, Li ZW. Numerical simulation of natural convection of nanofluid in a square enclosure: Effects due to uncertainties of viscosity and thermal conductivity. Int $\mathbf{J}$ Heat Mass Transf 2008;51:4506-16. doi:10.1016/j.ijheatmasstransfer.2007.12.019.

[111] Zamzamian A, Oskouie SN, Doosthoseini A, Joneidi A, Pazouki M. Experimental investigation of forced convective heat transfer coefficient in nanofluids of Al2O3/EG and $\mathrm{CuO} / \mathrm{EG}$ in a double pipe and plate heat exchangers under turbulent flow. Exp Therm Fluid Sci 2011;35:495-502. doi:10.1016/j.expthermflusci.2010.11.013.

[112] Kanjirakat A, Sadr R. Heat transfer performance of SiO2-water nanofluid in a plate heat exchanger. Proc. ASME 2012 Summer Heat Transf. Conf., Rio Grande, Puerto Rico: 2012.

[113] Kabeel AE, Abou El Maaty T, El Samadony Y. The effect of using nano-particles on corrugated plate heat exchanger performance. Appl Therm Eng 2013;52:221-9. 
doi:10.1016/j.applthermaleng.2012.11.027.

[114] Khairul MA, Alim MA, Mahbubul IM, Saidur R, Hepbasli A, Hossain A. Heat transfer performance and exergy analyses of a corrugated plate heat exchanger using metal oxide nanofluids. Int Commun Heat Mass Transf 2014;50:8-14. doi:10.1016/j.icheatmasstransfer.2013.11.006.

[115] Elias MM, Saidur R, Rahim N a., Sohel MR, Mahbubul IM. Performance Investigation of a Plate Heat Exchanger Using Nanofluid with Different Chevron Angle. Adv Mater Res 2013;832:254-9. doi:10.4028/www.scientific.net/AMR.832.254.

[116] Abed AM, Alghoul MA, Sopian K, Mohammed HA, Majdi H sh, Al-Shamani AN. Design characteristics of corrugated trapezoidal plate heat exchangers using nanofluids. Chem Eng Process Process Intensif 2015;87:88-103. doi:10.1016/j.cep.2014.11.005.

[117] Tabari ZT, Heris SZ. Heat Transfer Performance of Milk Pasteurization Plate Heat Exchangers Using MWCNT/Water Nanofluid. J Dispers Sci Technol 2015;36:196-204. doi:10.1080/01932691.2014.894917.

[118] Goodarzi M, Amiri A, Goodarzi MS, Safaei MR, Karimipour A, Languri EM, et al. Investigation of heat transfer and pressure drop of a counter flow corrugated plate heat exchanger using MWCNT based nanofluids. Int Commun Heat Mass Transf 2015;66:172-9. doi:10.1016/j.icheatmasstransfer.2015.05.002.

[119] Unverdi M, Islamoglu Y. Characteristics of heat transfer and pressure drop in a chevron-type plate heat exchanger with Al2O3/water nanofluids. Therm Sci 2016:97.

[120] Prashant, Singh G, Sarao T. Experimental Analysis of Heat Transfer and Friction Factor in Plate Heat Exchanger with Different Orientations Using Al2O3 Nanofluids. Int J Eng 
2016;29:1450-8.

[121] Barzegarian R, Moraveji MK, Aloueyan A. Experimental investigation on heat transfer characteristics and pressure drop of BPHE (brazed plate heat exchanger) using TiO2-water nanofluid. Exp Therm Fluid Sci 2016;74:11-8. doi:10.1016/j.expthermflusci.2015.11.018.

[122] Sun B, Peng C, Zuo R, Yang D, Li H. Investigation on the flow and convective heat transfer characteristics of nanofluids in the plate heat exchanger. Exp Therm Fluid Sci 2016;76:75-86. doi:10.1016/j.expthermflusci.2016.03.005.

[123] Taghizadeh-Tabari Z, Zeinali Heris S, Moradi M, Kahani M. The study on application of $\mathrm{TiO} 2 /$ water nanofluid in plate heat exchanger of milk pasteurization industries. Renew Sustain Energy Rev 2016;58:1318-26. doi:10.1016/j.rser.2015.12.292.

[124] Pandey SD, Nema VK. Experimental analysis of heat transfer and friction factor of nanofluid as a coolant in a corrugated plate heat exchanger. Exp Therm Fluid Sci 2012;38:248-56. doi:10.1016/j.expthermflusci.2011.12.013.

[125] Tiwari AK, Ghosh P, Sarkar J. Performance comparison of the plate heat exchanger using different nanofluids. Exp Therm Fluid Sci 2013;49:141-51. doi:10.1016/j.expthermflusci.2013.04.012.

[126] Tiwari AK, Ghosh P, Sarkar J. Heat transfer and pressure drop characteristics of CeO2/water nanofluid in plate heat exchanger. Appl Therm Eng 2013;57:24-32. doi:10.1016/j.applthermaleng.2013.03.047.

[127] Tiwari AK, Ghosh P, Sarkar J. Particle concentration levels of various nanofluids in plate heat exchanger for best performance. Int J Heat Mass Transf 2015;89:1110-8. doi:10.1016/j.ijheatmasstransfer.2015.05.118. 
[128] Tiwari AK, Ghosh P, Sarkar J, Dahiya H, Parekh J. Numerical investigation of heat transfer and fluid flow in plate heat exchanger using nanofluids. Int J Therm Sci 2014;85:93-103. doi:10.1016/j.ijthermalsci.2014.06.015.

[129] Kumar V, Tiwari AK, Ghosh SK. Effect of variable spacing on performance of plate heat exchanger using nanofluids. Energy 2016;114:1107-19. doi:10.1016/j.energy.2016.08.091.

[130] Kumar V, Tiwari AK, Ghosh SK. Effect of chevron angle on heat transfer performance in plate heat exchanger using ZnO/water nanofluid. Energy Convers Manag 2016;118:142-54. doi:10.1016/j.enconman.2016.03.086.

[131] Jokar A, O’Halloran SP. Heat Transfer and Fluid Flow Analysis of Nanofluids in Corrugated Plate Heat Exchangers Using Computational Fluid Dynamics Simulation. J Therm Sci Eng Appl 2013;5:011002. doi:10.1115/1.4007777.

[132] Gherasim I, Galanis N, Nguyen CT. Numerical study of nanofluid flow and heat transfer in a plate heat exchanger. Comput Therm Sci 2013;5:317-32.

[133] Sarafraz MM, Hormozi F. Heat transfer, pressure drop and fouling studies of multi-walled carbon nanotube nano-fluids inside a plate heat exchanger. Exp Therm Fluid Sci 2016;72:111. doi:10.1016/j.expthermflusci.2015.11.004.

[134] Ham J, Kim J, Cho H. Theoretical analysis of thermal performance in a plate type liquid heat exchanger using various nanofluids based on LiBr solution. Appl Therm Eng 2016;108:1020-32. doi:10.1016/j.applthermaleng.2016.07.196.

[135] Stogiannis IA, Mouza AA, Paras S V. Efficacy of SiO2 nanofluids in a miniature plate heat exchanger with undulated surface. Int J Therm Sci 2015;92:230-8. doi:10.1016/j.ijthermalsci.2015.01.035. 
[136] Maré T, Halelfadl S, Sow O, Estellé P, Duret S, Bazantay F. Comparison of the thermal performances of two nanofluids at low temperature in a plate heat exchanger. Exp Therm Fluid Sci 2011;35:1535-43. doi:10.1016/j.expthermflusci.2011.07.004.

[137] Fard MH, Talaie MR, Nasr S. Numerical and experimental investigation of heat transfer of $\mathrm{ZnO} /$ Water nanofluid in the concentric tube and plate heat exchangers. Therm Sci 2011;15:183-94. doi:10.2298/TSCI091103048H.

[138] Ray DR, Das DK, Vajjha RS. Experimental and numerical investigations of nanofluids performance in a compact minichannel plate heat exchanger. Int J Heat Mass Transf 2014;71:732-46. doi:10.1016/j.ijheatmasstransfer.2013.12.072.

[139] Huang D, Wu Z, Sunden B. Effects of hybrid nanofluid mixture in plate heat exchangers. Exp Therm Fluid Sci 2016;72:190-6. doi:10.1016/j.expthermflusci.2015.11.009.

[140] Behrangzade A, Heyhat MM. The effect of using nano-silver dispersed water based nanofluid as a passive method for energy efficiency enhancement in a plate heat exchanger. Appl Therm Eng 2016;102:311-7. doi:10.1016/j.applthermaleng.2016.03.051.

[141] Pantzali MN, Mouza AA, Paras S V. Investigating the efficacy of nanofluids as coolants in plate heat exchangers (PHE). Chem Eng Sci 2009;64:3290-300. doi:10.1016/j.ces.2009.04.004.

[142] Taws M, Nguyen CT, Galanis N, Gherasim I. Experimental Investigation of Nanofluid Heat Transfer in a Plate Heat Exchanger. ASME 2012 Heat Transf. Summer Conf., Rio Grande, Puerto Rico: 2012.

[143] Huang D, Wu Z, Sunden B. Pressure drop and convective heat transfer of Al2O3/water and MWCNT/water nanofluids in a chevron plate heat exchanger. Int J Heat Mass Transf 
2015;89:620-6. doi:10.1016/j.ijheatmasstransfer.2015.05.082.

[144] Cieśliński JT, Fiuk A, Miciak W, Siemieńczuk B. Performance of a Plate Heat Exchanger Operated with Water-A12O3 Nanofluid. Appl Mech Mater 2016;831:188-97. doi:10.4028/www.scientific.net/AMM.831.188.

[145] Bhattad A, Sarkar J, Ghosh P. Discrete phase numerical model and experimental study of hybrid nanofluid heat transfer and pressure drop in plate heat exchanger. Int Commun Heat Mass Transf 2018;91:262-73. doi:10.1016/j.icheatmasstransfer.2017.12.020.

[146] Pourhoseini SH, Naghizadeh N, Hoseinzadeh H. Effect of silver-water nanofluid on heat transfer performance of a plate heat exchanger: An experimental and theoretical study. Powder Technol 2018;332:279-86. doi:10.1016/j.powtec.2018.03.058.

[147] Wang Z, Wu Z, Han F, Wadsö L, Sundén B. Experimental comparative evaluation of a graphene nanofluid coolant in miniature plate heat exchanger. Int J Therm Sci 2018;130:148-56. doi:10.1016/j.ijthermalsci.2018.04.021.

[148] Elias MM, Saidur R, Ben-Mansour R, Hepbasli A, Rahim NA, Jesbains K. Heat transfer and pressure drop characteristics of a plate heat exchanger using water based $\mathrm{A} 12 \mathrm{O} 3$ nanofluid for $30^{\circ}$ and $60^{\circ}$ chevron angles. Heat Mass Transf 2018:2907-16. doi:10.1007/s00231-0182335-1.

[149] Tohidi A, Hosseinalipour SM, Taheri P, Nouri NM, Mujumdar AS. Chaotic advection induced heat transfer enhancement in a chevron-type plate heat exchanger. Heat Mass Transf 2013;49:1535-48. doi:10.1007/s00231-013-1180-5.

[150] Bamorovat Abadi G, Moon C, Kim KC. Experimental study on single-phase heat transfer and pressure drop of refrigerants in a plate heat exchanger with metal-foam-filled channels. 
Appl Therm Eng 2016;102:423-31. doi:10.1016/j.applthermaleng.2016.03.099.

[151] Bamorovat Abadi G, Kim DY, Yoon SY, Kim KC. Thermal performance of a 10-kW phasechange plate heat exchanger with metal foam filled channels. Appl Therm Eng 2016;99:790801. doi:10.1016/j.applthermaleng.2016.01.156.

[152] Jung K, Kang BH, Kim S. Effects of pulsating flow on evaporation of refrigerant in a plate heat exchanger. 3rd Asian Conf. Refrig. Air-condition, Gyeongju, Korea: 2006. doi:10.1081/E-EEE2-120046011.

[153] ZHANG G, TIAN M, ZHOU S. Simulation and analysis of flow pattern in cross-corrugated plate heat exchangers*. J Hydrodyn Ser B 2006;18:547-51.

[154] Fiebig M. Embedded vortices in internal flow: heat transfer and pressure loss enhancement. Int J Heat Fluid Flow 1995;16:376-88. doi:10.1016/0142-727X(95)00043-P.

[155] Xuan Y, Roetzel W. Conceptions for heat transfer correlation of nanofluids. Int J Heat Mass Transf 2000;43:3701-7. doi:10.1016/S0017-9310(99)00369-5.

[156] Wen D, Ding Y. Experimental investigation into convective heat transfer of nanofluids at the entrance region under laminar flow conditions. Int J Heat Mass Transf 2004;47:5181-8. doi:10.1016/j.ijheatmasstransfer.2004.07.012.

[157] Abbasian Arani AA, Amani J. Experimental investigation of diameter effect on heat transfer performance and pressure drop of TiO 2-water nanofluid. Exp Therm Fluid Sci 2013;44:520_ 33. doi:10.1016/j.expthermflusci.2012.08.014.

[158] Zhang J, Diao Y, Zhao Y, Zhang Y. Experimental study of TiO2-water nanofluid flow and heat transfer characteristics in a multiport minichannel flat tube. Int J Heat Mass Transf 2014;79:628-38. doi:10.1016/j.ijheatmasstransfer.2014.08.071. 
[159] Wen D, Ding Y. Effect on Heat Transfer of Particle Migration in Suspensions of Nanoparticles Flowing Through Minichannels. ASME 2nd Int. Conf. Microchannels Minichannels, Rochester, New York, USA: 2004, p. 939-46.

[160] Pak BC, Cho YI. Hydrodynamic and heat transfer study of dispersed fluids with submicron metallic oxide particles. Exp Heat Transf 1998;11:151-70. doi:10.1080/08916159808946559.

[161] Qiang LI, Yimin X. Convective heat transfer and flow characteristics of Cu-water nanofluid. Sci China (Series E) 2002;45:2002.

[162] Xuan Y, Li Q. Investigation on Convective Heat Transfer and Flow Features of Nanofluids. J Heat Transfer 2003;125:151. doi:10.1115/1.1532008.

[163] Heris SZ, Etemad SG, Esfahany MN. Experimental investigation of oxide nanofluids laminar flow convective heat transfer. Int Commun Heat Mass Transf 2006;33:529-35. doi:10.1016/j.icheatmasstransfer.2006.01.005.

[164] Nasiri M, Etemad SG, Bagheri R. Experimental heat transfer of nanofluid through an annular duct. Int Commun Heat Mass Transf 2011;38:958-63. doi:10.1016/j.icheatmasstransfer.2011.04.011.

[165] Hojjat M, Etemad SG, Bagheri R, Thibault J. Convective heat transfer of non-Newtonian nanofluids through a uniformly heated circular tube. Int J Therm Sci 2011;50:525-31. doi:10.1016/j.ijthermalsci.2010.11.006.

[166] Kayhani MH, Soltanzadeh H, Heyhat MM, Nazari M, Kowsary F. Experimental study of convective heat transfer and pressure drop of $\mathrm{TiO}$ 2/water nanofluid. Int Commun Heat Mass Transf 2012;39:456-62. doi:10.1016/j.icheatmasstransfer.2012.01.004.

[167] He Y, Jin Y, Chen H, Ding Y, Cang D, Lu H. Heat transfer and flow behaviour of aqueous 
suspensions of $\mathrm{TiO} 2$ nanoparticles (nanofluids) flowing upward through a vertical pipe. Int $\mathrm{J}$ Heat Mass Transf 2007;50:2272-81. doi:10.1016/j.ijheatmasstransfer.2006.10.024.

[168] Syam Sundar L, Naik MT, Sharma KV, Singh MK, Siva Reddy TC. Experimental investigation of forced convection heat transfer and friction factor in a tube with $\mathrm{Fe} 3 \mathrm{O} 4$ magnetic nanofluid. Exp Therm Fluid Sci 2012;37:65-71. doi:10.1016/j.expthermflusci.2011.10.004.

[169] Gherasim I, Galanis N, Nguyen CT. Heat transfer and fluid flow in a plate heat exchanger. Part II: Assessment of laminar and two-equation turbulent models. Int J Therm Sci 2011;50:1499-511. doi:10.1016/j.ijthermalsci.2011.03.017.

[170] Zhang J, Diao Y, Zhao Y, Zhang Y. Thermal-Hydraulic Performance of SiC-Water and Al 2 O 3 -Water Nanofluids in the Minichannel. J Heat Transfer 2015;138:021705. doi:10.1115/1.4031699.

[171] Zhang J, Diao Y, Zhao Y, Zhang Y. An experimental investigation of heat transfer enhancement in minichannel: Combination of nanofluid and micro fin structure techniques. Exp Therm Fluid Sci 2017;81:21-32. doi:10.1016/j.expthermflusci.2016.10.001.

[172] Bergles AE, Blumenkrantz AR, Taborek J. Performance evaluation criteria for enhanced heat transfer surfaces. J Heat Transfer 1974:239-43.

[173] Webb RL. Performance evaluation criteria for use of enhanced heat transfer surfaces in heat exchanger design. Int J Heat Mass Transf 1981;24:715-26. doi:10.1016/00179310(81)90015-6.

[174] García A, Vicente PG, Viedma A. Experimental study of heat transfer enhancement with wire coil inserts in laminar-transition-turbulent regimes at different Prandtl numbers. Int J 
Heat Mass Transf 2005;48:4640-51. doi:10.1016/j.ijheatmasstransfer.2005.04.024.

[175] Hsieh YY, Lin TF. Evaporation Heat Transfer and Pressure Drop of Refrigerant R-410A Flow in a Vertical Plate Heat Exchanger. J Heat Transfer 2003;125:852. doi:10.1115/1.1518498.

[176] Vakili-Farahani F, Amalfi RL, Thome JR. Two-phase flow and boiling of R245fa in a $1 \mathrm{~mm}$ pressing depth plate heat exchanger - Part II: flow boiling heat transfer. Interfacial Phenom Heat Transf 2014;2:343-61.

[177] Solotych V, Lee D, Kim J, Amalfi RL, Thome JR. Boiling heat transfer and two-phase pressure drops within compact plate heat exchangers: Experiments and flow visualizations. Int J Heat Mass Transf 2016;94:239-53. doi:10.1016/j.ijheatmasstransfer.2015.11.037.

[178] Desideri A, Zhang J, Kærn MR, Ommen TS, Wronski J, Lemort V, et al. An experimental analysis of flow boiling and pressure drop in a brazed plate heat exchanger for organic Rankine cycle power systems. Int J Heat Mass Transf 2017;113:6-21. doi:10.1016/j.ijheatmasstransfer.2017.05.063.

[179] Zhang J, Desideri A, Kærn MR, Ommen TS, Wronski J, Haglind F. Flow boiling heat transfer and pressure drop characteristics of R134a, R1234yf and R1234ze in a plate heat exchanger for organic Rankine cycle units. Int J Heat Mass Transf 2017;108:1787-801. doi:10.1016/j.ijheatmasstransfer.2017.01.026.

[180] Thome JR, Kim J. Encyclopedia of two-phase heat transfer and flow II special topics and applications. Singapore: World Scientific Publishing Co Pte Ltd; 2015.

[181] Fang X, Chen Y, Zhang H, Chen W, Dong A, Wang R. Heat transfer and critical heat flux of nanofluid boiling: A comprehensive review. Renew Sustain Energy Rev 2016;62:924-40. 
doi:10.1016/j.rser.2016.05.047. 